\title{
Leadership, creativity and innovation: A meta-analytic review
}

Allan Lee ${ }^{1}$, Alison Legood ${ }^{1}$, David Hughes ${ }^{2}$, Amy Wei Tian ${ }^{3}$, Alexander Newman $^{4}$, and Caroline Knight ${ }^{3}$

${ }^{1}$ Corresponding Author -

University of Exeter Business School,

University of Exeter,

Rennes Drive,

Exeter, EX4 4PU

allan.lee@exeter.ac.uk

+44(0) 1392726109

\footnotetext{
${ }^{2}$ Alliance Manchester Business School, University of Manchester

${ }^{3}$ Curtin Business School, Curtin University

${ }^{4}$ Deakin Business School, Deakin University
} 


\title{
Leadership, creativity, and innovation: A meta-analytic review
}

\author{
Abstract \\ This paper reports the most comprehensive meta-analytic examination of the relationship \\ between leadership and both followers' creative and innovative performance. Specifically, we \\ examined thirteen leadership variables (transformational, transactional, ethical, humble, \\ leader-member exchange, benevolent, authoritarian, entrepreneurial, authentic, servant, \\ empowering, supportive, and destructive) using data from 266 studies. In addition to \\ providing robustly estimated correlations, we explore two theoretically and pragmatically \\ important issues: the relative importance of the different leadership constructs and \\ moderators of the relationship between leadership and employee creativity and innovation. \\ Regrading creative performance, authentic, empowering, and entrepreneurial leadership \\ demonstrated the strongest relationships. For innovative performance, both transactional \\ (contingent reward) and supportive leadership appear particularly relevant. The current study \\ synthesizes an important, burgeoning, diverse body of research, and in doing so, generates \\ nuanced evidence that can be used to guide theoretical advancements, improved research \\ designs, and up-to-date policy recommendations regarding leading for creativity, and \\ innovation.
}

Keywords: Leadership; creativity; innovation; LMX; empowerment 


\section{Leadership, creativity and innovation: A meta-analytic review}

Organizational growth depends on the ability to generate novel ideas and to select and implement the most promising of those novel ideas. In short, creativity (idea generation) and innovation (idea implementation) are essential for organizational survival and success (Anderson, Potocnik, \& Zhou, 2014). Accordingly, organizational research has focussed on identifying antecedents of workplace creativity and innovation (Zhou \& Hoever, 2014) in order to develop theoretical models and evidence-based guidance for enhancing workplace creativity and innovation. Leadership is posited as a crucial antecedent because leaders shape the working environment, resource allocation, the nature of work tasks (e.g., Liden, Sparrowe, \& Wayne, 1997), and influence employee behavior by leveraging existing employee assets (e.g., motivation) or developing new ones (e.g., learning: Fischer, Dietz, \& Antonakis, 2017).

Numerous studies have explored the relationship between leadership and employee creativity and innovation (see Hughes, Lee, Tian, Newman, \& Legood, 2018 for a review), however, the number of highly intercorrelated leader variables studied has produced a complex literature that hinders understanding and the development of evidence-based practical recommendations (DeRue, Nahrgang, Wellman, \& Humphrey, 2011; Hughes, et al., 2018). Studying multiple leader variables concurrently should allow us to begin to identify which are most strongly associated with workplace creativity and which are most strongly associated with innovation. Further, the boundary conditions of these relationships are not well understood (Hughes et al., 2018). A lack of clarity regarding these issues means three major questions currently undermine the utility of research in this field:

1. Which (if any) leadership variable(s) is the strongest predictor of creativity and innovation? 
2. What is the relative importance of different leadership variables with creativity and innovation?

3. What are the boundary conditions influencing the relationship between a given leadership variable and creativity and innovation?

The goal of this meta-analysis is to provide a quantitative review of the current literature in relation to these three questions. Previous reviews have examined leadership and creativity, but have tended to be narrative in design (e.g., Anderson et al., 2014; Hughes et al., 2018; Mainemelis, Kark, \& Epitropaki, 2015; Reiter-Palmon \& Ilies, 2004; Rank, Pace, \& Frese, 2004; Zhou \& Shalley, 2003) or provided theoretical overviews and identified 'gaps' in the literature (Klijn \& Tomic, 2010; Shalley \& Gilson, 2004). In contrast, we seek to examine the relative importance of thirteen leadership variables for individual-level creativity and innovation and investigate several methodologically and theoretically derived moderators of the relationship between leadership and creativity and innovation.

\section{Literature review and research question development}

\section{Creativity and innovation}

We define creativity and innovation according to a recent systematic and critical review of existing definitions:

"Workplace creativity concerns the cognitive and behavioral processes applied when attempting to generate novel ideas. Workplace innovation concerns the processes applied when attempting to implement new ideas" (Hughes et al., 2018, p. 3).

Evident from this definition, creativity and innovation are distinct but related constructs. Creativity is largely an intrapersonal activity concerned with the generation of truly novel ideas, whereas innovation is a largely interpersonal activity concerned with introducing new ideas (which can come from anyone/anywhere) that fit the context, garnering support from others, and ultimately implementing the new ideas (Hughes et al., 2018). Typically, the 
leaders' role is to facilitate employees by providing them with the appropriate resources and environment. However, because creativity and innovation are fundamentally different (see Hughes et al., 2018, Table 2), and are driven by different antecedents (e.g., Axtell et al., 2000; Hughes et al., 2018; Magadley \& Birdi, 2012), it would be surprising if a single leadership style were appropriate for both (Hughes et al., 2018; Perry-Smith \& Mannucci, 2017). Indeed, recent conceptual frameworks suggest that when creating, employees require psychologically safe and motivating spaces that enable them to engage in cognitively flexible thought (Perry-Smith \& Mannucci, 2017). In contrast, when innovating, employees need social influence and legitimacy which can be provided through leader support and endorsement (Perry-Smith \& Mannucci, 2017). Creative ideas rarely lead to innovation unless shared with relevant and/or influential organizational members. It is possible, then, that certain leader variables will be of differential importance to creativity and innovation.

Despite the conceptual and empirical uniqueness of creativity and innovation, previous meta-analyses have tended to combine them into a single variable (e.g., Kim, Beehr, \& Prewett, 2018; Lee, Willis, \& Tian, 2018; Lee, Lyubovnikova, Tian, \& Knight, 2019). However, we follow contemporary theoretical and empirical arguments and consider creativity and innovation separately (Anderson et al., 2014; Hughes et al., 2018), enabling the exploration of differential associations with the leader styles examined.

\section{Leadership, creativity and innovation}

Previous meta-analyses examining leadership variables have often ignored creativity and innovation as outcomes (e.g., Banks, Gooty, Ross, Williams, \& Harrington, 2018; Hoch, Bommer, Dulebohn, \& Wu, 2018; Martin, Guillaume, Thomas, Lee, \& Epitropaki, 2016), focused on a limited range of leadership predictors, or have combined creative and innovative performance into a single variable (Banks, McCauley, Gardner, \& Guler, 2016; Hammond, Neff, Farr, Schwall, \& Zhao, 2011; Lee et al., 2018; Lee et al., 2019; Rosing, Frese, \& 
Bausch, 2011; Wang, Oh, Courtright, \& Colbert, 2011). Here, we extend these findings by examining and comparing the correlations between thirteen leadership variables and individual-level employee creativity and innovation, separately. In doing so, we seek to address three pertinent issues regarding the main effects between leadership and employee creativity and innovation.

First, there is notable variation in the magnitude and even direction of reported effect sizes (Hughes et al., 2018), rendering interpretation difficult, especially when they are derived from moderately sized samples. Meta-analytic investigations, such as this, provide a much more robust estimate of population effects. Second, the increased power provided by meta-analytic investigations allows for robust estimation of moderating effects that are not possible within individual studies. Therefore, we also address the call made by Hughes and colleagues (2018) to explore possible moderating variables in the categories of study design, broad context (e.g., industry type), and local context (e.g., follower gender). Third, it is unclear whether the many contemporary leadership variables in the literature (e.g., ethical, benevolent) account for unique variance in creative and innovative behavior when considered alongside other leadership variables.

Our review identified thirteen leadership variables which have been repeatedly found to be associated with creativity and/or innovation. It is well established that certain leadership styles draw upon common theoretical arguments when explaining how their effects are transmitted (e.g., Lemoine, Hartnell, \& Leroy, 2019). Accordingly, we grouped the thirteen leadership variables into five theoretically homogenous categories - the full-range model, moral leadership, motivational leadership, relational leadership, and negative leadership and discuss how they are expected to relate to creative and innovative performance, below. 
The full-range leadership model (Avolio \& Bass, 1991), comprises transformational, transactional, and laissez-faire leadership. The model stems from Bass's (1985) argument that theories of the time focused only on basic exchanges with followers (transactional) and failed to explain how leaders influence followers to transcend self-interest for the greater good of the organization (transformational). In response, Bass proposed a model encompassing four transformational and two transactional leadership factors.

Transformational leadership (Bass, 1985) consists of four dimensions: idealized influence (i.e., leader behavior that is admirable and charismatic), inspirational motivation (i.e., articulating an appealing and inspiring vision), intellectual stimulation (i.e., challenging follower assumptions and listening to their ideas), and individualized consideration (i.e., mentoring and coaching according to follower's unique needs). In relation to creativity and innovation, transformational leadership is said to be beneficial for two main reasons. Firstly, transformational leaders tend to inspire and motivate through expressing an energizing vision which in turn "motivate[s] people to do their best" (Avolio \& Bass, 1988, p. 33). Second, the intellectual stimulation element encourages followers to think divergently, question assumptions, and take risks (Bass, 1985). Such actions tend to promote an open and explorative mindset (Keller, 2006) and empower followers to experiment with ideas and undertake active problem solving (e.g., Jung, Chow, \& Wu, 2003; Shin \& Zhou, 2003).

Transactional leadership is focussed on achievement-related exchanges: Contingent reward describes the provision of incentives following successful performance, whereas management by exception describes the degree to which leaders take corrective action either in an active or passive manner (Bass, 1985; Yukl, 1999). As such, transactional leaders achieve influence by clarifying goals, the use of rewards and incentives, and intervening only when necessary (Bass, 1985). Although the rewarding of goal-attainment may foster extrinsic motivation, transactional leadership is unlikely to instil intrinsic motivation, unlike 
transformational leadership, which actively encourages experimentation. Thus, it is often suggested that transformational leadership will be more strongly associated with creative and innovative behaviour than transactional leadership (Hughes et al, 2018). Further, the transactional component may be perceived as controlling and demotivating, thus dampening innovation further (Deci \& Ryan, 1987). Despite this, the contingent reward component may be effective in promoting creativity and innovation when the rewards are contingent on employee creativity (Rickards, Chen, \& Moger, 2001).

The other two dimensions of transactional leadership are grouped under the term management by exception. The management-by-exception category includes monitoring employee performance and taking corrective action when problems arise. Active management by exception refers to the extent to which leaders strive to identify, and then redress, poor performance or errors. Passive management by exception describes leaders who avoid involvement until these shortfalls or errors arise. Followers of leaders who employ management-by-exception tend to be dissatisfied and demotivated and, as such, this style is unlikely to foster creativity or innovation (Kim \& Lee, 2011).

Transformational and transactional aspects of the full-range model are argued to be unique and additive such that transformational leadership augments the effect of transactional leadership (Bass \& Avolio, 1993). Evidence of the relative importance of transformational over transactional leadership is mixed. For instance, a meta-analysis examining the relative importance of the full-range leadership model demonstrated that transformational leadership explained more variance in group performance, perceptions of leader effectiveness, and satisfaction with leader, whereas contingent rewards were most strongly associated with follower job satisfaction (Derue et al., 2011). Similarly, Piccolo, Bono, Heinitz, Rowold, Duehr and Judge (2012) concluded, based on primary data, that transformational leadership and contingent reward leadership are highly correlated but empirically distinct factors that 
explain significant incremental variance in outcomes. Studies exploring the relative effects of the components of the full-range model on creativity and innovation are rare (e.g., Kim \& Lee, 2011), but what evidence there is, suggests that transformational leadership has stronger effects on both follower creativity (Kark, Van Dijk, \& Vashdi, 2018) and innovation (e.g., Lee, 2008).

\section{Moral Leadership: Authentic, servant, ethical, and humble}

Authentic, servant, and ethical leadership represent three morally based forms of positive leadership (Hoch et al., 2018) which are often grouped together (Lemoine et al., 2019). We also consider humble leadership, a new addition to the field, within this category. Ethical Leadership (Brown, Trevino, \& Harrison, 2005) focuses on the demonstration of normatively appropriate conduct through personal actions and interpersonal relationships (i.e., modelling behavioral standards for followers). Authentic leaders (Walumbwa, Avolio, Gardner, Wernsing, \& Peterson, 2008) are said to have a relatively heightened level of selfawareness, an internalized moral perspective, process information in a balanced and ethical manner, and deal with followers in a transparent and fair way (i.e., relational transparency). Servant leadership (e.g., Ehrhart, 2004) emphasizes personal integrity in life, work, family, and community (Ehrhart, 2004). Humble leadership concerns a willingness to be self-aware in social interactions, an appreciation for others' strengths and contributions, and teachability (Owens \& Hekman, 2012). Humility is an important trait for an ethical leader to possess (de Vries, 2012), and thus, humble leadership also reflects an ethical/moral style. When explaining the effects of moral leadership styles, most studies draw upon social learning theory or social exchange theory (Lemoine et al., 2019).

In line with social learning theory (Bandura, 1986), ethical and humble leaders model behaviors such as acknowledging their personal limits and mistakes, and being open to inputs from others, that when emulated by followers are believed to foster creativity and innovation 
(Lemoine et al., 2019; Owens \& Hekman, 2012). Similarly, authentic and servant leadership utilize social learning explanations. For instance, the self-awareness at the heart of authentic leadership allows leaders to exhibit openness in their behavior and 'lead by example' (Walumbwa et al., 2008), which, when emulated by followers, is believed to stimulate followers to engage creatively with their work (Seibert, Kraimer, \& Liden, 2001).

Social exchange theory is also frequently evoked. For example, Ilies, Morgeson and Nahrgang (2005) argue that authentic leaders demonstrate unbiased processing of selfrelevant information, personal integrity, and authentic relations that contribute to positive social exchanges with followers (i.e., positive emotions, trust and respect), which in turn fosters a degree of emotional and psychological safety that empowers employees to propose unconventional ideas (Avolio, Gardner, Walumbwa, Luthans, \& May, 2004; Edmondson, 1999; Prati, Douglas, Ferris, Ammeter, \& Buckley, 2003; Rego, Sousa, Cunha, Correia, \& Saur-Amaral, 2007).

Although servant, authentic, ethical, and humble leadership have conceptual similarities, each is argued to have unique qualities or at least unique emphases. For instance, Lemoine et al. (2019) note that servant leadership emphasizes a focus on benefiting multiple stakeholders and the wider community, authentic leadership emphasizes self-awareness and internal consistency, and ethical leadership emphasizes normative standards. Typically, moral styles explain unique variance in outcomes when modelled alongside transformational leadership (e.g., Banks et al., 2016; Hoch et al., 2018; Lee et al., 2019; Ng \& Feldman, 2015).

\section{Motivating Leadership: Empowering and Entrepreneurial}

Empowering leadership involves highlighting the significance of followers' work and communicating confidence in their ability by delegating authority, encouraging self-directed and autonomous decision making, coaching, sharing information, and asking for input (e.g., Kirkman \& Rosen, 1999). Such leadership behaviors are conceptually relevant to both 
creativity and innovation through the development of self-determination and intrinsic motivation (e.g., Zhang \& Bartol, 2010). For instance, participation in decision making and perceptions of autonomy are vital preconditions for creative outcomes (e.g., Amabile, 1996) because they encourage autonomous exploration of different approaches and problem solutions (Li \& Zhang, 2016). Intrinsically motivated followers are also more likely to be prepared to leveraging their existing knowledge (Parker, Wall, \& Jackson, 1997), which leads to increased performance on tasks requiring creativity (e.g., cognitive flexibility, conceptual understanding; Kehr, 2004) and exhibit greater persistence in face of obstacles that arise when innovating (Deci \& Ryan, 2000).

Entrepreneurial leadership encourages followers to identify and exploit entrepreneurial opportunities for value creation (Renko, 2018), and thus aims to motivate employees to contribute to creative activities (Chen 2007; Cai, Lysova, Khapova, \& Bossink, 2019). Further, entrepreneurial leaders provide creative support, for example, by designing and adjusting achievable goals aimed to rouse follower perseverance and by working with employees to generate different perspectives. Thus, in line with social cognitive/learning theory, entrepreneurial leaders foster employees' creativity and innovation through three main pathways: role modelling entrepreneurial behaviors (vicarious learning), encouraging and directing followers to engage in entrepreneurial activity (subjective persuasion and enhanced affective states), and providing opportunities for followers to be entrepreneurial (mastery experiences) (Newman, Tse, Schwarz, \& Nielsen, 2018; Renko, Tarabishy, Carsrud, \& Brännback, 2015).

Empowering and entrepreneurial leadership styles overlap because both encourage followers to go beyond the status quo and to do things differently. However, although empowering leaders involve followers in the processes of problem-solving and decisionmaking (Miao, Newman, Schwarz, \& Xu, 2013), they do not necessarily provide specific 
role-modeling and guidance aimed at encouraging creative or innovative behavior. In contrast, entrepreneurial leaders demonstrate entrepreneurial behaviors to followers and thus directly encourage the implementation of creative ideas at work (Newman et al., 2018).

\section{Relational Leadership: LMX, Supportive, Benevolent}

LMX, benevolent, and supportive leadership, which we categorize as relational variables, focus on building positive relationships by demonstrating care and concern for followers. LMX is inherently relational and defined as the quality of exchange between leader and employee (Graen \& Cashman, 1975). Recent studies suggest that because followers with a high-quality LMX relationship are likely to feel obliged to reciprocate the positive exchanges with their leader (Blau, 1964; Gouldner, 1960), they are more likely to engage in discretionary processes such creative (e.g., Meng, Tan, \& Li., 2017) and/or innovative behavior (Pan, Sun, \& Chow, 2012; Turunc, Celik, Tabak, \& Kabak, 2010). According to the social exchange theory, followers will work hard, undertake creative activities and exhibit high creativity in exchange for support, trust and other resources from leaders (Xu, Huang, Lam, \& Miao, 2012). It is also argued that in a high-quality LMX relationship the follower should have more autonomy and decision-making latitude (Graen \& Uhl-Bien, 1995), which are positively related to creativity and innovation.

Supportive leadership describes a cluster of leader behaviors that aim to provide access to resources, assistance, and encouragement in the face of difficulties. Supportive leaders' encouragement may enhance followers' creative self-efficacy, an important antecedent of creativity and innovation (Tierney \& Farmer, 2002), that is malleable and can be reinforced by social support (e.g., Bandura, 1997). Further, supportive leaders should also increase creative behavior by increasing employee's interest at work (Oldham \& Cummings, 1996). Thus, supportive leadership should be positively related to both creativity and innovation. 
Benevolent leadership is characterized by exhibitions of individualized and holistic concern and care for followers (Farh \& Cheng, 2000). In line with social exchange theory (Blau, 1964), the positive treatment provided by the benevolent leader to followers leads them to reciprocate by engaging in behaviors they feel are desired (Lin, Ma, Zhang, Li, \& Jiang, 2018). Although some studies have argued that this may result in less creativity and innovation as subordinates follow their leaders orders without questioning them (Wang, Xue, $\& \mathrm{Su}, 2010)$, researchers have generally argued for a positive relationship between benevolent leadership and both creativity and innovation because leaders generally state that they are valued (Dedahanov, Lee, Rhee, \& Yoon, 2016; Lin et al., 2018). The relationship aspect of benevolent leadership overlaps with LMX and supervisor support, but the involvement in followers' personal lives and treatment of followers 'as family' distinguishes benevolence from these variables (e.g., Hiller, Sin, Ponnapalli, Ozgen, 2019).

\section{Negative Leadership: Destructive and Authoritarian}

Typically, leadership research has focused on finding the most effective leadership methods and has focused on positive forms of leadership (Schyns \& Schilling, 2013), perhaps to the detriment of our understanding of ineffective or negative leadership. In the category of negative leadership, we focus on two leadership styles: authoritarian and destructive. An authoritarian leader "asserts absolute authority and control over subordinates and demands unquestionable obedience" (Cheng, Chou, Wu, Huang, \& Farh, 2004, p. 91). Authoritarian leaders exert control over followers by initiating structure, issuing rules, promising rewards for compliance, and threatening punishment for disobedience (Aryee, Chen, Sun, \& Debrah, 2007). Authoritarian leaders' demand absolute obedience from followers and, produce a climate of fear and caution (Pellegrini \& Scandura, 2008), meaning that followers are less likely to show initiative and proactivity to generate novel approaches to perform their tasks. 
Therefore, authoritarian leadership decreases the expression of personal ideas or participation in problem solving, thereby inhibiting employee creativity and innovation.

Destructive leadership refers to voluntary acts committed towards followers that most people would perceive as harmful, such as, mocking, belittlement, rudeness, and breaking promises (Tepper, 2000). The experience of abusive supervision typically evokes negative emotions, such as fear (e.g., Kiewitz, Restubog, Shoss, Garcia, \& Tang, 2016), and promotes avoidance and self-protection in followers (Kiewitz et al., 2016). Because followers are required to invest large amounts of psychological resources to cope with the stress resulting from abusive supervision, they are more likely to experience emotional exhaustion $(\mathrm{Wu} \&$ $\mathrm{Hu}, 2009$ ) and reduce their emotional and psychological investment in their jobs (Chi \& Liang, 2013). As a result, followers of abusive leaders are less likely to create useful and novel ideas, thereby decreasing their creativity $(\mathrm{Gu}$, Song, \& Wu, 2016). This is supported by meta-analytic research showing that negative, activating moods with an avoidance motivation and a prevention focus (fear, anxiety) were associated with lower levels of creativity (Baas, De Dreu, \& Nijstad, 2008). A related form of destructive leadership is despotic leadership (e.g., Naseer, Raja, Syed, Donia, \& Darr, 2016). Despotic leaders are self-interested, morally corrupt, have low ethical standards (De Hoogh \& Den Hartog, 2008), and egoistic motives designed to manipulate and exploit followers for personal gain (Naseer et al., 2016). Followers of despotic leaders are argued to indirectly retaliate by reduced engagement in desired behaviors. Therefore, followers are likely to withhold creative behaviors to thwart a despotic leader. Reduced creative performance may also result from the notion that when a leader's ethical character is dubious, they are less able to persuade followers to achieve individual and/or organizational objectives (Kanungo, 2001). Studies investigating the effects of destructive leaders have focused on the effects on creativity rather than innovation (e.g., Gu et al., 2016; Naseer et al., 2016). 
Authoritarian and destructive leadership are viewed as negative leadership variables because of their association with an array of socially and organisationally undesirable effects (Kiazad, Restubog, Zagenczyk, Kiewitz, \& Tang, 2010). Although authoritarian and destructive leadership are clearly conceptually distinct from positive leadership styles, such as transformational leadership, there is little empirical work that compares the relative effects of authoritarian and destructive leadership to each other or positive leadership styles. Looking at meta-analytic correlations (without directly testing the relative importance), Schyns and Schilling (2013) reported that most correlations with follower outcomes are higher for positive (e.g., transformational leadership) rather than negative leadership styles.

\section{Leadership and Creativity Summary}

As discussed, numerous leadership variables are theorized and have been shown to correlate with followers' creative and innovative behavior. A key aim of the current metaanalysis is to summarize this vast literature and to better understand the relationships these leadership styles have with both outcomes. Relatedly, we seek to determine which variable(s), has the strongest relationship with creativity and innovation.

Research question 1: Which leadership style(s) is most strongly associated with creativity and innovation

\section{Relative Importance of Leadership Style on Creativity and Innovation}

The second aim of this meta-analysis is to explore the relative importance of different leadership variables on creativity and innovation. This is important because it is currently unclear whether the many leadership variables are redundant or have unique effects, and which variable(s), if any, is most strongly related to creativity and innovation (Hughes et al., 2018). This is reflective of wider concerns in the leadership literature regarding construct proliferation and construct redundancy (DeRue et al., 2011; Shaffer, DeGeest, \& Li, 2016). Put simply, many ostensibly distinct leadership variables share considerable conceptual and 
empirical overlap, often correlating between .7- .9 (e.g., Banks et al., 2018; Lemoine et al., 2019; Shaffer et al., 2016). In response, there have been several studies attempting to identify if various leadership styles are distinct and in which circumstances the distinct elements are important. For instance, five recent meta-analyses have examined whether authentic (Banks et al., 2016), ethical (Ng \& Feldman, 2015), servant (Lee et al., 2019) and empowering (Lee et al., 2018) leadership explain incremental variance over and above established variables such as transformational leadership (see also Hoch et al., 2018) on various employee outcomes. These studies found that different leadership styles are relatively more important than transformational leadership for some outcomes but not others.

Extending this work, we meta-analytically compare the relative effects of thirteen leadership varaibles on creativity and innovation. In doing so, we answer recent calls for comparative examinations of different leadership styles (e.g., Piccolo et al., 2012) in a comprehensive examination of leadership, creativity and innovation. Because typical study designs examine just a single leader variable (see Hunter, Bedell-Avers, \& Mumford, 2007; Piccolo et al., 2012), too few primary studies exist for us to examine the relative contribution of all thirteen leadership variables in one model. Instead, we explore their relative importance in two steps. First, we examine the relative variance explained by each variable over and above that explained by the full-range leadership model (transformational and transactional leadership). The full-range model represents a broad model that is also the most studied. Second, we examine the relative predictive validity of leadership variables within the different leadership categories. For example, we compare the effects of ethical, servant, authentic and humble leadership within the moral leadership category.

Research question 2: Which leadership variable(s) have the largest relative association with creativity and innovation above transformational and transactional leadership? 
Research question 3: Which moral leadership variable(s) have the largest relative association with creativity and innovation.

Research question 4: Which relational leadership variable(s) have the largest relative association with creativity and innovation.

Research question 5: Which motivational leadership variable(s) have the largest relative association with creativity and innovation.

Research question 6: Which negative leadership variable(s) have the largest relative association with creativity and innovation.

\section{Leadership and Creativity: Moderation}

In their recent review, Hughes and colleagues noted that "the magnitude of the relationship between leadership and creativity and innovation is hugely variable... In some cases from near-zero to large, and in others, ranging from moderately negative to moderately positive.” (p. 554). To illustrate, some studies find large associations between transformational leadership and creativity (e.g., Rickards et al., 2001) and innovation (e.g., Slatten, 2014), whereas other find non-significant associations (e.g., Cai et al., 2019; Chen, Farh, Campbell-Bush, Wu, \& Wu, 2013). This pattern is common across leadership variables and Hughes and colleagues (2018) note three likely reasons for the variability. First, the use of sub-standard and variable study designs (e.g., cross-sectional vs. longitudinal) and varied assessments of creativity and innovation (e.g., employee self-rating, leader rating, 'objective' metric). Second, Hughes et al. (2018, p.554) argue that "the variation might represent the fact that the very nature of creativity and innovation differs across organizational sectors and roles". Third, they argue that the variation might reflect the presence of moderating variables within the organizational context (e.g., dynamics of specific leader-follower relationships). The current meta-analysis provides a unique opportunity to explore a small number of variables from each of these three potential causes of variation. We chose moderators that are 
largely exogenous (e.g., sex, industry) in nature and thus are relatively free from endogeneity biases (i.e., common method, missing variable, reciprocal effects). As a result, any moderating effects can be interpreted as relatively reliable (see Antonakis, Bendahan, Jacquart, \& Lalive, 2010; 2014; Hughes et al., 2018).

\section{Methodological Moderators}

From this category, we explore whether leadership-creativity/innovation correlations are moderated by the use of common-source (i.e., self-rated creativity or innovation) versus non-common source (i.e., other-rated or objective measures) data and cross-sectional (i.e., leadership and creativity/innovation are measured concurrently) versus time-separated (i.e., creativity or innovation is measured at a later time point than leadership) designs. The use of time-separated designs and/or non-common source data represent two methods frequently employed to try and reduce endogeneity biases arising from the use of common methods (see Podsakoff, MacKenzie, \& Podsakoff, 2012).

\section{Industrial Context}

Hughes et al. (2018) suggest that creativity and innovation might look somewhat different across industrial contexts and note that "no papers have empirically examined crossindustry effects, thus, direct comparisons across industry boundaries would be an interesting avenue for future research." (p. 554). Accordingly, we explore knowledge intensity as an industrial-level moderator. Work within high knowledge-intensive industries uses a body of complex knowledge (von Nordenflycht, 2010) to "produce qualified objects and/or services by utilizing the knowledge of the personnel as the major resource" (Alvesson, 2000, p. 1101). Examples of knowledge-intensive industries include high-tech service (e.g., telecommunication, computer design), professional service (e.g., law and accounting, banking and insurance, consultancy, education, information service industries), and high-tech 
manufacturing (e.g., pharmaceuticals, aerospace, biotechnology) (Alvesson, 2000; Liao, Fei, \& Chen, 2007).

We argue that it is possible that knowledge-intensive organizations require different leadership styles than traditional labor-intensive (e.g., hospitality) or capital-intensive industries (e.g., low-tech manufacturing) (Terpstra \& Rozell, 1993). In knowledge-intensive work contexts, leadership focusing on fostering employees' feeling of intrinsic motivation, trust, and empowerment, is likely to be more effective at encouraging knowledge sharing and creativity/innovation (Donate \& de Pablo, 2015). For example, supportive and empowering leadership should be more effective in enhancing employee creativity and innovation, than authoritarian leadership, in high knowledge-intensive industries (Chuang, Jackson, \& Jiang, 2016; Srivastava, Bartol, \& Locke, 2006).

\section{National Culture - Power Distance}

As an additional contextual variable, we explore the possible moderating role of culture because what is expected of leaders varies due to cultural expectations (House, Javidan, Hanges, \& Dorfman, 2002) meaning that national culture can influence the effectiveness of different leadership styles (e.g., Dorfman, Sully de Luque, Hanges, \& Javidan, 2010; Hofstede, 2001; House \& Aditya, 1997; Sully de Luque, Javidan, Hanges, \& Dorfman, 2011). Here, we use the Hofstede cultural dimensions to examine national cultural based on the geographic locations where studies were drawn (Hofstede, 2001). We focus on power distance, which refers to beliefs about status, authority, and power in organizations and therefore has a stronger theoretical link to followers' reactions to different leadership styles than many other cultural values (Kirkman, Chen, Farh, Chen, \& Lowe, 2009; Ng, Koh, Ang, Kennedy, \& Chan, 2011). Societies with a high-power distance orientation expect more and are more receptive to top-down direction from their leaders (Javidan, House, Dorfman, Hanges, \& De Luque, 2006). For instance, Den Hartog et al. (1999) suggest that in high 
power distance societies there should exist a less negative attitude towards authoritarian leadership. By contrast, in low power-distance cultures, people are argued to be less respectful of authority and more likely to view leaders as equal in status to others (Rockstuhl, Dulebohn, Ang, \& Shore, 2012). Thus, the norms of low power-distance cultures should be more compatible with leadership styles that promote equality and delegation between leaders and followers (Hale \& Fields, 2007).

\section{Follower Gender}

Finally, we consider follower gender as a possible within-context moderator. Typically, compared to females, males are more likely to attain creative eminence across various domains in the arts and sciences (Abra \& Valentine-French, 1991; Cole \& Zuckerman 1987; Piirto, 1991). There are many potential reasons for this effect (see Baer \& Kaufman, 2008; Abraham, 2016) but the most promising explanations seem to revolve around what has been entitled a "male hubris-female humility" bias (Furnham, Fong, \& Martin, 1999). That is, males typically rate themselves better at most things than women including having greater creative self-efficacy, especially within scientific and competitive contexts (Hughes, Furnham, \& Batey, 2013; Kaufman, 2006). Because "self-assessments of our abilities influence what we attempt to do and how much effort we expend ... [they] are important not just to self-perception but also to performance” (Hughes et al., 2012, p. 76). Similarly, males' creative efforts are typically more resilient to the nature of feedback and rewards. For example, studies of creative writing have demonstrated that introducing rewardbased extrinsic motivators or performance evaluations had no discernible effect on the males' creative output but negatively affected female performance (Baer, 1998). Thus, it is possible that by working to increase the confidence of their employees and motivating in the 'appropriate' way, leaders might have a relatively more important role to play for female 
followers. In other words, male creative hubris perhaps acts as a buffer, regardless of how a leader behaves.

\section{Moderation summary}

To summarize, meta-analytic studies provide a unique opportunity to explore moderators that are difficult to test in single studies. To that end the current research seeks to explore boundary conditions that might help to explain some of the variation in effect sizes found across primary studies (Hughes et al., 2018).

Research question 7: To what extent do study design features, national culture, industrial context and follower gender impact the strength of the relationship between different leadership styles and creativity/innovation?

\section{Method}

\section{Literature Search and Study Inclusion}

A thorough search was conducted in order to identify published and unpublished samples that examined the relationship between leadership variables with creativity or innovation. To ensure completeness, we used electronic databases, EBSCOHost, Emerald, ProQuest, PsycINFO, and ScienceDirect, which collectively include a wide range of management and applied psychology journals. We included the search terms: lead*, creativity, creative

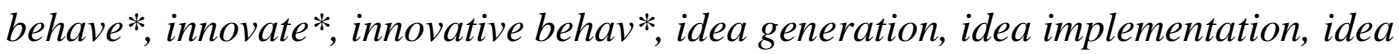
promotion. This process yielded a total of 10,043 results including journal articles, dissertations, books, conference papers and proceedings, and working papers. In addition, we examined the reference lists from any relevant review articles and most recent papers (Hughes et al., 2018; Mainemelis et al., 2015; Reiter-Palmon \& Ilies, 2004; Wang et al., 2011; Watt, Steele, \& Den Hartog, 2019). Finally, we searched for possible unpublished and in-press studies by sending email solicitations to members of the Academy of Management OB listserv. 
A study had to meet several criteria to be included in our final analysis. First, it had to include a zero-order correlation between a leadership variable and either creativity or innovation at the individual-level. Individual creativity was assessed with 'objective' measures (e.g., creativity bonuses: Liao, Liu, \& Loi, 2010) or leader-, peer-, customer- and self-ratings of commonly used creative behavior scales (e.g., Zhou \& George, 2001). Innovation was assessed with leader-, customer- and self-ratings of commonly used innovative behavior scales (e.g., Janssen, 2000; Scott \& Bruce, 1994). We only included studies that used follower ratings of leadership variables. While a handful of studies in the search used leader-rating of their own style (e.g., Van Dyne, Jehn \& Cummings, 2002), the overwhelming majority used follower-rating and thus we chose to focus only on these studies. The second inclusion criteria for our analyses was that the study included the sample size used to arrive at the correlation. Third, the sample had to be independent from other studies; if a sample overlapped with another study, it was only included once. After coding these papers, we looked for the most common leadership variables examined. Like other researchers (e.g., Cole, Walter, Bedeian, \& O'Boyle, 2012; Hoch et al., 2018), we made an $a$ priori decision that we would include a leadership variable if it was included in four or more samples with either creativity or innovation. This criterion ruled out several leadership variables that were represented by fewer than four studies, including inclusive (2), ambidextrous (2) or empathetic (1) leadership. Our final sample included studies related to transformational, transactional, LMX, empowering/participative, servant, ethical/moral, authentic, humble, supportive, benevolent, entrepreneurial, authoritarian, and destructive leadership. In total, 255 publications and 266 independent samples (several publications reported multiple samples) met these criteria. Appendix $\mathrm{C}$ provides details of the studies included for every meta-correlation produced in our analyses. 
In addition to exploring the correlations between the leadership variables, creativity and innovation, the current study is also concerned with relative effects of different leadership variables and moderators. For moderation analyses we coded pertinent information from the studies, such as the national culture in which each study was conducted, the percentage of leaders and/or followers that were males, and the average age of followers. In order to determine the relative effects of the different leadership variables, we required metaanalytic correlations between leadership variables. For some of these relationships we were able to rely on recently published meta-analytic papers to get the required correlation. For example, recent studies provided meta-analytic correlations between leadership styles such as ethical and empowering leadership and transformational leadership (e.g., Hoch et al., 2018; Lee et al., 2018). For other leadership variables, no previous meta-analyses were available and thus we conducted a separate search to find correlations between styles. Appendix A highlights the source of all these meta-analytic correlations.

\section{Meta-Analysis Procedure}

The meta-analysis utilized the Hunter and Schmidt (2015) approach. This method produces a sample weighted mean correlation (r) and a mean correlation corrected for unreliability in both independent and dependent variables, henceforth referred to as the corrected population correlation $(\rho)$. Missing values (i.e., reliability of either predictor or criterion) were estimated by adding the average value across the studies in which information was provided (Hunter \& Schmidt, 2015). If a study included multiple operationalisations of either creativity or innovation, we averaged the correlation to create a single correlation. For example, a study by Harris and colleagues (2014) included both supervisor and co-worker ratings of employee creativity (Study 2), which was averaged. The $95 \%$ confidence intervals ( $95 \% \mathrm{CI})$ of the sample-weighted mean correlation and the $80 \%$ credibility intervals $(80 \%$ $\mathrm{CV}$ ) of the corrected population correlation were also reported. Confidence intervals estimate 
variability in the sample-weighted mean correlation that is due to sampling error; credibility intervals estimate variability in the individual correlations across studies that is due to moderating variables (Whitener, 1990). If the 95\% confidence interval does not include zero, we can be confident that the sample-weighted mean correlation differs from zero. Confidence intervals can also be used to determine whether two estimates differ from each other; two estimates are considered different when their confidence intervals are non-overlapping.

If the $80 \%$ credibility interval of the corrected population correlation is large it is indicative of the fact that there is considerable variation across studies, and moderators are likely to be operating. We also estimated the percentage of variance accounted for in the corrected population correlation by sampling and measurement error (\% VE, Hunter \& Schmidt, 1990). Typically, moderators are likely to be present when sampling and measurement error accounts for less than $75 \%$ of the variance (Hunter \& Schmidt, 1990). To explore moderators between the different leadership variables and creativity and/or innovation we ran random effects meta-regression. Meta-regression explores whether there is a significant difference between studies according to different levels of either continuous or categorical moderators (Borenstein, Hedges, Higgins \& Rothstein, 2011). We conducted these moderator analyses using the meta-analytic software, Comprehensive Meta-Analysis (version 2.2.064, 2011, Biostat, Englewood, NJ). We first tested several methodological moderators, including: rater (whether creativity/innovation was self- or otherrated/objective); time (whether the creativity/innovation was measured at the same time or later than the leadership variable); and whether the studies were published or unpublished (to test for any publication bias). After testing these methodological moderators, we then explored theoretical moderators, including the national culture in which the studies were conducted, the industry context, and the gender of the followers. For national culture, each study was given a score for power-distance, ranging from 1 (representing very low power- 
distance) to 100 (indicating very high power-distance) based on the culture taxonomies obtained from Hofstede (2001). For example, according to Hofstede's research, Austria has very low power distance with a score of 11. Malaysia, on the other hand, has a score of 100. We took two steps to code the industry knowledge intensity. First, we coded the studies' industry if the information was available. We then coded the studies' industry type as a dichotomous/nominal variable where 1 represents high-knowledge intensity, and 0 represents low-medium-knowledge intensity. We coded industry knowledge intensity based on Alvesson's (2000) and OECD's definition of knowledge intensive industries (Liao et al., 2007; Miles, 2008). For example, industries that are considered to be high knowledge intensity typically include high-tech service (e.g., telecommunication, computer and related activities), professional service (e.g., law and accounting, banking and insurance, health and social work, management, consultancy, education, information service industries), and hightech manufacturing (e.g., pharmaceuticals, aerospace, and biotechnology industries). Industries that are considered low-medium industry knowledge intensity typically include retail trade, wholesale trade, and textile and clothing manufacturing (Miles, 2008).

Additionally, we followed the categorization used by Classification of Economic Activities in the European Community (NACE) to categorise industries based on Alvesson's definition if the industry appears as a sub-category of the main knowledge intensive industry categories. For example, computer and related activities category can include industries such as industries reported as database activities and software/IT service. Finally, follower gender was coded as the proportion of the followers in the study that were male.

To test for relative predictive validity of the different leadership variables, we conducted relative weights analysis (Johnson, 2000). Relative weights analysis tests the relative contribution (i.e., relative importance) among multiple (often correlated) predictor variables in a regression analysis. Relative weights analysis converts the total variance 
predicted in a regression model ( $\mathrm{R}$ squared) into weights that accurately reflect the proportional contribution of the various predictor variables. Specifically, these weights represent an additive decomposition of the total model and can be interpreted as the proportion (percentage) of variance explained in the outcome (e.g., creativity) that is appropriately attributed to each leadership variable. As such relative weights analysis considers only the relative contribution of a variable to total variance explained. The analysis addresses the problem caused by correlated predictors by using a variable transformation approach that takes into account a variable's contribution to an outcome by itself and in combination with other predictor variables (see Johnson, 2000; Johnson \& LeBreton, 2004; LeBreton \& Tonidandel, 2008; Tonidandel \& LeBreton, 2011, for a detailed discussion of relative weight analysis). The use of relative weights in meta-analyses has gained great popularity and is common in management literature (see Hoch et al., 2018; Kurtessis, Eisenberger, Ford, Buffardi, Stewart, \& Adis, 2017; Lee et al., 2018). To conduct the analysis, we first created a correlation matrix, which included meta-analytic correlations between all study variables (where possible). To reduce common source variance and common method bias, the correlations between leadership and creativity and/or innovation, were based on non-common source estimates (cf. Podsakoff et al., 2012). In other words, we did not include self-rated creative or innovative performance in these analyses. Using this correlation matrix, we conducted relative weights analyses, using Tonidandel and LeBreton's (2011) guidelines.

\section{Results}

Meta-analytic coefficients between the various leadership variables and individuallevel creativity and innovation are displayed in Table 1. We formulated effect sizes using all studies, studies using only self-reported creativity and innovation, and studies using only nonself-report creativity and innovation. 
All the leadership variables, except transactional leadership, were significantly associated with creativity. Entrepreneurial leadership and authentic leadership shared the largest correlation with creativity $(\rho=.47)$. As indicated by non-overlapping $95 \%$ confidence intervals, authentic leadership had a significantly larger association than transformational, benevolent, humble, supportive, authoritarian, and destructive. The association between transactional leadership and creativity was found to be more variable - with confidence intervals that crossed zero. To better understand the effects of transactional leadership we examined its dimensions separately. Of the 12 studies examining transactional leadership and creativity, 5 examined contingent reward as a separate dimension, while 3 focused on management by exception. We found that contingent reward was positively and significantly associated with creativity, whereas management by exception had a non-significant association with creativity (See Table 2). Table 2 also shows the meta-analytic coefficients for the dimensions of transformational leadership; no significant differences were found across the four dimensions of transformational leadership $(\rho=.20-.22)$.

Insert Table 1 about here

Insert Table 2 about here

Innovation was significantly associated with all the leadership variables. However, we did not find enough primary studies to explore the associations between innovation and authentic, humble, authoritarian, or destructive leadership. Further, we did not find enough primary studies that explored the dimensions of transformational leadership in relation to follower innovation. The largest association was found between supportive leadership and innovation $(\rho=.38)$. To better understand the effects of transactional leadership we examined its dimensions and found that contingent reward was positively and significantly associated with creativity $(\rho=.30)$, however we were unable to find enough studies that examined the effect of management by exception on individual innovation (See Table 2). 


\section{Moderation Analysis}

Table 3 displays the results of our moderation analyses. Further, the meta-analytic correlations between the leadership variables and creativity/innovation at different levels of the dichotomous moderators (i.e., published vs unpublished studies; high vs low knowledge intensive industry; cross-sectional vs time separated design) can be found in Appendix B.

First, we tested for the possibility of publication bias, by examining any difference in effect between published and unpublished studies. As highlighted in Table 3, we found no differences in the relationship between creativity and LMX, transformational, and empowering leadership dependent on whether the data was published or unpublished. Further we found no evidence for publication bias in the relationship between transformational leadership and innovation. The aforementioned relationships were the only ones with enough unpublished data to test for differences.

Regarding methodological moderators, we found some evidence that correlations were inflated when either creativity or innovation was self-rated as opposed to other-rated (e.g., leader-rated) or objectively assessed (See Table 3). For example, we found that the relationship between transformational leadership and both creativity and innovation was significantly larger when common-source data was used. We also found evidence for inflated correlations when leadership and creativity were assessed concurrently. Specifically, the link between creativity and both LMX and empowering leadership was weaker when these variables were time separated compared to measured simultaneously. For many leadership variables there were too few time-separated designs to conduct this moderation analysis.

\section{Insert Table 3 About Here}

We respect to knowledge intensity, we found little evidence that this aspect of industrial context influenced the strength of the relationship between leadership and either 
creativity or innovation. However, LMX and supportive leaders had a weaker impact on innovation in knowledge intensive industries.

In terms of national culture, we explored the moderating effect of power distance. In most of the analyses power distance had no significant effect on the relationship between leadership and either creativity or innovation. However, for empowering leadership, we found that the relationship with creativity was weaker in cultures higher in power distance. Conversely, we found that the relationship between supportive leadership and creativity and was stronger in cultures higher in power distance. Similarly, the relationship between servant leadership and innovation was stronger in such cultures.

Finally, we found evidence that several leadership variables had stronger correlations when the proportion of female followers was higher compared to lower. Correlations between creativity and LMX, authentic, servant, and destructive leadership were weaker when there was a higher proportion of male followers. Correlations between LMX and innovation were weaker when there was a higher proportion of male followers.

\section{Relative Weights Analysis}

We explored the relative association between the leadership variables and creativity and innovation. We conducted this analysis in two steps. First, we compared the effect of each leadership variable to the full-range leadership model (i.e., transformational and transactional leadership). Where possible we did this for both creativity and innovation. For transactional leadership, we decided to focus on contingent rewards. Measures that combined contingent reward and management by exception had inconsistent effects on both creativity and innovation (i.e., 95\% confidence intervals that overlapped zero) but the contingent reward dimension had positive and significant effects on creativity/innovation (See Table 2). The second step focused on comparing the effect of leadership variables within the different categories. For instance, we examined the relative importance of authentic, servant, ethical 
and humble leadership on creativity to ascertain which of these "moral styles" had the strongest relationship to creativity. For all these analyses, we decided to exclude self-rated creativity and innovation because our moderation analyses suggested that self-rated creativity and innovation was often significantly more strongly related to leadership - suggesting the potential for common-method bias (Podsakoff et al., 2012).

\section{Insert Table 4 about here}

Table 4 shows the relative weight analyses comparing each of the leadership variables with transformational and contingent reward leadership. Relative weights analysis considers the relative contribution of a variable to total variance explained by the model tested. Regarding creativity, empowering (75\%), LMX (51\%), servant (47\%), ethical (62\%) and authentic $(77 \%)$ leadership explained relatively more of the total predictable variance explained by the model than did transformational leadership or contingent reward leadership, whereas authoritarian (13\%), destructive (26\%), and supportive (15\%) leadership accounted for relatively less of the total predictable variance explained than did transformational and contingent reward leadership. For humble and benevolent styles of leadership, we could only find enough studies to compare with transformational leadership. Humble leadership explained slightly more of the total predictable variance (53\%) in creativity compared to transformational leadership, whereas benevolent explained much less $(27 \%)$. These findings suggest that authentic and empowering leadership have the strongest relationship to creativity over transformational and contingent reward leadership. It is also interesting to note that apart from authoritarian and supportive leadership, contingent reward accounted for the smallest proportion of the variance explained in creativity.

Regarding innovation, a different pattern was evident, with only supportive leadership $(58 \%)$ explaining relatively more of the total predictable variance than the full-range leadership model. It is interesting to note that except for supportive leadership, the use of 
contingent rewards accounted for the greatest proportion of the variance explained in innovation. As far as data allowed, we conducted additional relative weights analysis within the categories of leadership. As shown in Table 5, we explored the relative weights of the relational oriented leadership variables: LMX, supportive and benevolent leadership. Of these, LMX (59\%) explained a larger proportion of the variance explained than either supportive (19\%) or benevolent leadership (22\%). However, supportive leadership (80\%) explained a greater proportion of the variance explained in innovation compared to LMX (20\%). Of the moral-based leadership styles, we found that authentic leadership accounted for the largest proportion of the variance explained in creativity (54\%), whereas compared to servant leadership, ethical leadership (74\%) accounted for most of the variance explained in innovation. For the two motivational styles, empowering leadership $(60 \%)$ was the strongest predictor of innovation, explaining a higher proportion of the explained variance compared to entrepreneurial leadership (40\%). Finally, of the negative leadership styles, destructive leadership (82\%) explained a much larger proportion of the variance explained in creativity compared to authoritarian (18\%).

Additionally, as shown in Table 5, we compared the relative importance of the different dimensions of transformational leadership on creativity. Of the 4 dimensions, individualized consideration explained the largest proportion of the variance explained in creativity (29\%), however generally speaking the 4 dimensions accounted for similar proportions of the variance explained.

Insert Table 5 about here

\section{Discussion}

To date, leadership, creativity and innovation research has produced a complex literature that hinders understanding and the development of evidence-based practical recommendations. We aimed to add clarity to the area by synthesizing empirical work to 
produce robust estimates of the correlations between thirteen leadership variables and employee creativity and innovation, explore the relative importance of different leader variables, and explore some potential moderators. We discuss our findings in relation to our three key aims below.

\section{Research question 1: Which leadership variable(s) is(are) most strongly associated with creativity and innovation?}

Several previous meta-analyses reported positive correlations between authentic, servant, transformational, and empowering leadership and either creativity, innovation, or some combination of the two (Banks et al., 2016; Lee et al., 2018; Lee et al., 2019; Rosing et al., 2011; Wang et al., 2011). Our findings help to further clarify the field in two main ways. First, we estimated correlations for creativity and innovation, separately. Second, because we estimated reliable correlations between thirteen leadership variables and creativity and innovation, we were better able to summarise the vast literature.

Before we discuss some of the more nuanced results, we first offer a broad overview of the main trend in the analysis, namely, that almost all leader variables are modestly correlated with employee creativity and innovation. In pursuit of parsimony, we sorted the thirteen variables into five theoretically-informed categories: the full-range model, moral leadership, motivational leadership, relational leadership, and negative leadership. We found that twelve of thirteen leadership styles had significant associations with creativity regardless of where they were categorized. Transactional leadership was the only style not to share a significant correlation. Due to data limitations, we were unable to estimate the association between innovation and authentic, destructive, or humble leadership. All the nine remaining variables (i.e., transformational, transactional, LMX, servant, ethical, entrepreneurial, authoritarian, benevolent, and supportive leadership) shared significant correlations with innovative behaviour. This is an interesting finding that can be interpreted in different ways. 
One interpretation is that any of the leadership variables highlighted above will help leverage followers' creativity or innovation. Indeed, the same theoretical mechanisms have been posited to explain the effects of many different leadership variables (Hughes et al., 2018). For example, employee psychological empowerment (i.e., feelings of competence, purpose, autonomy, and impact) has been found to mediate the effects of transformational (e.g., Sun, Zhang, Qi, \& Chen, 2012), transactional (Wei, Yuan, \& Di, 2010), empowering (e.g., Zhang \& Bartol, 2010), and ethical (e.g., Javed, Khan, Bashir, \& Arjoon, 2017) leadership on creativity.

An alternative, perhaps more likely, explanation is that many leader variables are redundant, and their assessment tools assess overall attitudes regarding leaders rather than actual behaviors (Lee, Martin, Thomas, Guillaume, \& Maio, 2015). Current study designs preclude firm conclusions because they are plagued by endogeneity biases (i.e., the predictor variable is correlated with the error term of the outcome variable), which mean that ratings of leadership often correlate with outcomes such as employee creativity or innovation in two or more ways: (i) as a meaningful cause and (ii) due to errors such as common method bias, reciprocal effects, or relationships with a common cause (Antonakis et al., 2010, 2014; Banks et al., 2018; Hughes et al., 2018). However, it is likely that at least some leader variables are redundant and future research should prioritize efforts to identify which leader variables are unique and useful. Doing so would involve at least two steps. First, researchers should continue to identify overlap and uniqueness between leadership variables (e.g., Lemoine et al., 2019). Our relative weights analysis, discussed below, can also begin to shed some light on this matter by highlighting that while there is empirical overlap between the leadership variables, their correlations with creativity and innovation suggest there are also unique elements that can be drawn out. Arguably, the field would benefit most from a single taxonomy of important, behaviourally-focussed, leader variables that could then be combined 
in different ways to produce more complex 'styles'. Such an approach would allow for both parsimony and emergent complexity. Second, researchers would need to use methods that are resistant to endogeneity bias in order to establish causal links between leadership and creativity/innovation. This would involve the use of experimental studies or by using instrumental variables and longitudinal designs (see Hughes et al., 2018).

Turning to some more nuanced findings. First, authentic (a moral style) and entrepreneurial (a motivational style), two rather different leadership styles, had the largest association with individual creativity. Entrepreneurial leaders are often creative themselves and focus their resources on enabling followers to experiment and challenge the status quo (Renko et al., 2015). In contrast, authentic leaders focus on developing their followers in a more holistic manner, by role-modelling personally expressive and authentic behavior and providing opportunities for skill development and autonomy (e.g., Hoch et al., 2018). This would suggest that leaders can effectively influence creativity through behavioural modelling, providing autonomy, and being encouraging and honest.

Second, for individual innovation, supportive, empowering, and servant leadership had the strongest correlations. These findings tentatively suggest that employees are better able to innovate (i.e., promote and implement novel ideas) when their leaders become less 'leader-like' in the traditional sense. That is, when leaders act as facilitators and support and empower employees.

Third, "negative" leadership (i.e., authoritarian and destructive) typically had weaker associations with creativity compared to "positive" leadership, suggesting that the effects of negative leaders are less pronounced that the effects of more positive leadership styles, such as those focused on morals, relationships, or motivation. These results add to the growing literature on negative leadership and specifically to results from a previous meta-analysis 
which found that destructive leaders had stronger effects than constructive leaders for some follower outcomes, but not others (Schyns \& Schilling, 2013).

\section{Research questions 2-6: Which leadership variable(s) have the largest relative association with creativity and innovation?}

We used our uniquely comprehensive data set to conduct a series of analyses to address the fact that "it is unclear which leadership approaches are the strongest predictors because the literature has largely failed to examine the relative contribution of different leadership variables.” (Hughes et al., p. 564). Two previous meta-analyses, using a combined creativity and innovation variable, have examined relative effects, finding that empowering leadership had stronger effects than transformational leadership (Lee et al., 2018) and servant leadership (Lee et al., 2019) had stronger effects than transformational, ethical, or authentic leadership. Our study builds on these initial findings by testing a wider range of variables and considering their effects on individual-level creative and innovative behavior separately. Specifically, we estimated the relative effects of each leadership variable in comparison to the full-range leadership model (i.e., transformational leadership and contingent reward) and we estimated the relative effects of each leader style within the five theoretical categories (as far as data allowed). The findings of both analyses converged to present an interesting picture.

For creativity, the leader variables that had the strongest relative effects, when compared to the full range leadership model, were authentic, empowering, ethical, and LMX, whereas contingent reward was a particularly weak contributor. Overall, authentic leadership showed the largest relative effect over transformational and contingent reward leadership. Although spread across different theoretical groupings the commonality across these variables is that they focus on developing genuine and close relationships with followers through social exchanges including coaching, participative decision-making, showing concern, and relational transparency. Similarly, when compared within theoretical groupings, 
LMX and Authentic leadership were found to be particularly prominent. This suggests the same mechanism is at play, namely, that in order to facilitate creativity, leaders should develop close relationships with their employees which allow them to better leverage existing employee resources (e.g., cognitive skills, motivation; Fischer et al., 2017). This interpretation is consistent with current empirical evidence and theory (e.g., Amabile, 1996; Perry-Smith \& Mannucci, 2017) which shows that when creating, employees require psychologically safe environments characterised by a high degree of trust in which they feel able to engage in cognitively flexible thought and potentially spend time generating novel but useless ideas.

In almost direct contrast were the relative weights analyses for innovation. Authentic leadership and LMX were relatively unimportant, whereas supportive leadership showed the strongest relative effects. Interestingly, contingent reward was one of the most important leadership variables for innovation. The difference in the importance of contingent reward between creativity and innovation is one of the most striking findings, and again, consistent with theory and empirical evidence. Previous research has demonstrated that extrinsic rewards do little to provide the safe, autonomous conditions suited to generating novel ideas (Amabile, 1996; Perry-Smith \& Manucci, 2017) but that innovative work behaviour (i.e., promoting and implementing novel ideas) is not hampered by the presence of extrinsic rewards (Hughes et al., 2018; Perry-Smith \& Mannucci, 2017). It is probably the case that whereas creativity requires unbounded mental exploration that can be constrained by extrinsic rewards (e.g., Baer, Oldham, \& Cummings, 2003; Malik, Butt, \& Choi, 2015), the tasks central to innovation require a more focused, targeted, and persistent behavioural approach that is incentivised by tangible rewards (Behrens \& Patzelt, 2018). Equally, because innovation is applied in nature, it is probably easier to assess and to design appropriate 
performance-contingent rewards. Thus, it is perhaps unsurprising that extrinsic rewards are effective in promoting innovative work behavior (e.g., Honig-Haftel \& Martin, 1993).

Another notable finding was that supportive, empowering and entrepreneurial leadership proved to be strong predictors of innovative behavior. It is not surprising that entrepreneurial leadership was relevant because its scale assesses the degree to which the leader themselves innovates or explicitly encourages innovative employee behaviour. Similarly, empowering leaders tend to encourage employees to use their initiative in a selfdirected manner and provide the autonomy required to do so. Further, it seems that both empowering and supportive leadership scales are relatively unique from other scales in their categories because they contain a greater proportion of items that refer to the provision of instrumental, goal-directed-support (e.g., My leader is concerned that I work in a goaldirected manner; My supervisor takes pride in my accomplishments; My leader coordinates his/her goals with my goals; My supervisor supports my work group's effort; Help is available from my supervisor when I have a problem; Helps my work group focus on our goals) as opposed to social or emotional support focussed on meeting relational goals and improving employee wellbeing that is typical of other styles in those categories (e.g., servant, LMX, authentic). Thus, it appears that these leader styles encapsulate three important avenues through which leaders can facilitate employee innovation: role-modelling, providing autonomy, and providing instrumental, goal-directed support (e.g., social influence when attempting to promote and implement ideas; Perry-Smith \& Mannucci, 2017).

In sum, because creativity and innovation are fundamentally different (see Hughes et al., 2018, Table 2), and driven by different antecedents (e.g., Axtell, Holman, Unsworth, Wall, Waterson, \& Harrington, 2000; Hughes et al., 2018; Magadley \& Birdi, 2012) our separate analysis has revealed some interesting nuances. Specifically, leadership that focuses upon building close leader-follower relationship, characterized by a high degree of trust 
appear most effective in facilitating employee creativity. In contrast, leader behaviors characterized by providing by active role-modelling, providing autonomy, goal-directed support, and performance-contingent rewards appear most effective in facilitating employee innovation.

Research question 7: To what extent do study design features, national culture, industrial context, and follower gender impact the strength of the relationship between different leadership variables and creativity/innovation?

Previous studies have noted that a large amount of variation exists in the relationship between leadership and creativity/innovation (e.g., Hughes et al., 2018). This was echoed in our findings, as indicated by large $80 \%$ credibility intervals regarding the correlations between the leadership variables and both creativity and innovation. As such, we sought to explore some potential methodological and substantive moderators of the correlations between leadership and creativity and innovation.

\section{Methodological Moderators}

To test whether the main effects found in our analysis were influence by the methodology employed in the primary studies, we explored the effect of the two most common practices employed to reduce common method bias (see Podsakoff et al., 2012). The relationship between leadership and follower creativity and innovation was often larger when the outcome was self-rated compared to supervisor-rated or objectively measured and when studies were cross-sectional as opposed to time-lagged. However, for many leadership variables there were no significant differences based on these study design issues. It is also important to note that the two methods are inadequate to deal with all endogeneity biases (see Antonakis et al., 2010), which do influence effect sizes in the leadership, creativity, and innovation field, making it difficult to make firm conclusions (Hughes et al., 2018). Thus, we echo calls for future research to use stronger designs, including, experimental studies, proper 
longitudinal designs, and instrumental variables (see Hughes et al., 2018 for specific recommendations).

\section{Substantive moderators}

Industrial setting did not moderate correlations between most leadership variables and creativity and innovation. Thus, regardless of whether studies were conducted in knowledge intensive sectors or not, effects were largely consistent. However, we did find that supportive leadership and LMX (both relational variables) had a weaker relationship with innovation in more knowledge intensive industries. It is possible that these findings are spurious and due to chance but we can also speculate that because knowledge-intensive work is of an "intellectual nature" and the majority of employees are "well-educated" (Alvesson, 2000, p. 1101), they may feel less need for relational leadership and instead prefer leadership styles that promote self-reliance and initiative. Indeed, a strong supportive leadership style in this context could even make knowledge workers, feel less independent, less trusted, and as a result, use their competencies to be creative to a lesser extent (Burnett, Chiaburu, Shapiro, \& Li., 2015).

Another contextual variable examined was national culture. Focusing on societal-level power-distance, we found that culture moderated the correlations between empowering, servant, and supportive leadership and creativity (empowering and supportive) and innovation (servant). For empowering leadership, we found that higher levels of power distanced weakened the relationship with creativity. This is not surprising as cultures high in power distance may perceive empowering behavior such as the delegation of responsibility to be inconsistent with societal norms suggesting that only those with formal power should have authority and discretion, whereas the role of low power individuals is to carry out the explicit orders of superiors (Rockstuhl et al., 2012). As such individuals in high power distance societies may be less willing to accept and exercise discretionary power granted by leaders (e.g., Chow, Lo, Sha, \& Hong, 2006). 
In contrast, supportive and servant leadership had stronger effects on creativity and innovation, respectively, when power-distance was higher. High power-distance cultures adopt policies and norms that consider followers to be less important than leaders (Tyler, Lind, \& Huo, 2000) and expect followers to show deference and obedience (Li \& Sun, 2015). Thus, when leaders demonstrate individualized support to followers, it is likely perceived as a kindness that surpasses expectations and is received with gratitude (Lin et al., 2018). By contrast, followers in lower power-distance societies likely expect individualized support as the norm, meaning that supportive efforts confer weaker effects on behavior.

With regards to follower gender, five correlations were moderated. The higher the proportion of males in a team, the weaker the correlations between creativity and innovation and LMX, Authentic, Servant, and Destructive leadership. These results are in line with the “male hubris-female humility" bias (Furnham et al., 1999) and suggest that, on average, females' creative and innovative performance is more heavily aided and hindered by their leaders. This effect seems to be particularly pronounced for leader variables that have a strong social exchange component, suggesting that leaders' social interactions might be particularly important for harnessing the creative potential of female employees. Given these findings we argue that a fruitful area for future research is to further examine gender in relation to leadership, creativity and innovation. Research could, for example, explore the effect of gender dissimilarity between leaders and followers and continue to explore when the "male hubris-female humility" bias is observed.

\section{Limitations and Future Research Directions}

As with any meta-analysis, the results are bound by the data available in the primary studies. The leadership, creativity, and innovation literature is characterized by an overreliance on cross-sectional and correlational data, which are unable to provide robust estimates of causal effects, due to endogeneity biases (e.g., Antonakis et al., 2014; Fischer et 
al., 2017; Hughes et al., 2018). Thus, it is impossible to draw conclusions related to causality in our analyses. That said, there are strong theoretical grounds and mounting experimental evidence (e.g., Sosik, Kahai, Avolio, 1999; Jaussi \& Dionne, 2003) to suspect that leadership influences follower creativity and innovation

For some of the relationships in our analyses we had to rely on a small number of primary studies. For example, the relationship between entrepreneurial leadership and creativity was particularly strong but based on only three studies $(\mathrm{N}=820)$ and there were too few studies using non-common source data, to include entrepreneurial in our relative weight analysis. The lack of primary studies makes it impossible to derive strong conclusions since the results may have been strongly influenced by particularly strong or weak correlations. This limitation also highlights clear areas for future research by demonstrating which outcomes particularly require further investigation.

It is important to consider our meta-analytic findings in relation to the wider leadership literature. The literature has been subject to much evaluation in recent years - with high profile critiques of the conceptualization and measurement of prominent leadership variables (e.g., Alvesson \& Einola, 2019; Antonakis, Bendahan, Jacquart, \& Shamir, 2016; Bank et al., 2018; van Knippenberg \& Sitkin, 2013) and the way in which leadership studies are typically designed (e.g., Antonakis et al., 2010; Hughes et al., 2018). For instance, there have been recent and compelling critiques regarding the conceptualization and measurement of authentic leadership (Alvesson \& Einola, 2019), transformational leadership (van Knippenberg \& Sitkin, 2013), and charismatic leadership (Antonakis et al., 2016) which suggest that they are in some cases, "ill-defined, tautological, ideological and resist rigorous study" (Alvesson \& Einola, 2019, p. 12).

More generally, the leadership literature suffers from construct redundancy (Shaffer et al., 2016), with high correlations being observed between "different" leadership variables 
(e.g., Banks et al., 2018). The findings of our meta-analysis should be interpreted with these critiques in mind and even add weight to the argument. Appendix A shows the high metaanalytic correlations between the different leadership variables that we examined in relation to creativity and innovation. Our findings also show that all leadership variables, except for transactional leadership, showed significant relationships with creativity and innovation that were often hard to distinguish. These findings can be interpreted as indicative of construct redundancy, but they could also be due to factors that inflate and attenuate effects, such as endogeneity biases (see Banks et al., 2018). For instance, the high correlations observed in primary studies between transformational and entrepreneurial leadership (e.g., Newman et al., 2018) could be due to the fact that both measures are lack accuracy and precision (Hughes, 2018) meaning they capture overall positive leader evaluations (see Lee et al., 2015). Indeed, our results, which show differential effects of different leadership variables, suggest some uniqueness within some leader variables. If the uniqueness for each leader variable was identified and only that was assessed (i.e., remove construct irrelevant content) then scales would offer more nuanced and accurate assessments of the target constructs (Hughes, 2018). Accordingly, we echo the call for better measurement and study design than can reduce endogeneity biases and provide more accurate estimates of the relationship between leadership variables (e.g., Antonakis et al., 2010; Banks et al., 2018; Hughes et al., 2018; Lemoine et al., 2019).

\section{Practical Implications}

Although the limitations noted are non-trivial (see Hughes et al, 2018), our synthesis suggests some tentative implications for leaders. There are two notable findings in this regard that emanate from the fact that creativity and innovation are fundamentally different (see Hughes et al., 2018, Table 2). 
For enhancing individual-level creativity, leaders should try to enact behaviors that focus upon building close leader-follower relationship, characterized by a high degree of trust, as would be indicative of the relatively important leader variables of LMX, authentic, and empowering leadership. To help in this regard, organizations might wish to train leaders in such styles (see Baron \& Parent, 2015, for a recent evaluation of such training). In addition, leaders should be careful if trying 'buy' creativity through contingent rewards and would probably be better served to allow employees the autonomy and time needed to generate novel ideas - many of which will likely be of little tangible value yet important in the overall process. Similarly, organizations must create appropriate processes to allow for idea generation at work.

In contrast, when seeking to help employees innovate, leaders should behave in a manner that is characterized by actively role-modelling desired behaviors, providing autonomy, goal-directed support such as ensuring adequate resources and lending social influence to followers when required. Perhaps the key finding that emerged from our analysis relates to strong relationship between the use of a contingent rewards and innovation. Clearly, organizations should design their reward systems carefully and/or allow leaders to have the discretion to offer innovation-contingent rewards, when appropriate. 


\section{References}

\section{For references for studies included in meta-analysis see APPENDIX C}

Abra, J. C., \& Valentine-French, S. (1991). Gender differences in creative achievement: A survey of explanations. Genetic, Social, and General Psychology Monographs, 117, 233284.

Abraham, A. (2016). Gender and creativity: An overview of psychological and neuroscientific literature. Brain Imaging and Behavior, 10, 609-618. https://doi.org/10.1007/s11682-015-9410-8

Alvesson, M. (2000). Social identity and the problem of loyalty in knowledge- intensive companies. Journal of Management Studies, 37, 1101-1124. https://doi.org/10.1111/1467-6486.00218

Alvesson, M., \& Einola, K. (2019). Warning for excessive positivity: Authentic leadership and other traps in leadership studies. The Leadership Quarterly. https://doi.org/10.1016/j.leaqua.2019.04.001

Amabile, T. M. (1996). Creativity in context. Boulder, CO: Westview Press.

Anderson, N., Potocnik, K. \& Zhou, J. (2014). Innovation and creativity in organizations: A state-of-the-science review and prospective commentary. Journal of Management, 40, 1297-1333. https://doi.org/10.1177/0149206314527128

Antonakis, J., Bendahan, S., Jacquart, P., \& Lalive, R. (2010). On making causal claims: A review and recommendations. The Leadership Quarterly, 21, 1086-1120. https://doi.org/10.1016/j.leaqua.2010.10.010

Antonakis, J., Bendahan, S., Jacquart, P., \& Lalive, R. (2014). Causality and endogeneity: Problems and solutions. In D.V. Day (Ed.), The Oxford handbook of leadership and organizations (pp. 93-117). New York: Oxford University Press. 
Antonakis, J., Bastardoz, N., Jacquart, P., \& Shamir, B. (2016). Charisma: An ill-defined and ill-measured gift. Annual Review of Organizational Psychology and Organizational Behavior, 3, 293-319. https://doi.org/10.1146/annurev-orgpsych-041015-062305

Aryee, S., Chen, Z. X., Sun, L Y., \& Debrah, Y. A. (2007). Antecedents and outcomes of abusive supervision: Test of a trickle-down model. Journal of Applied Psychology, 92, 191-201. https://doi.org/10.1037/0021-9010.92.1.191

Avolio, B. J. \& Bass, B. M. (1988). Transformational leadership, charisma, and beyond. In J. G. Hunt, B. R. Baliga, H. P. Dachler, \& C. A. Schriesheim (Eds.), International leadership symposia series. Emerging leadership vistas (pp. 29 - 49). Lexington, MA, England: Lexington Books

Avolio, B., \& Bass, B. (1991). Full-range training of leadership. Binghamton, New York: Bass/Avolio \& Associates

Avolio, B. J., Gardner, W. L., Walumbwa, F. O., Luthans, F., \& May, D. R. (2004). Unlocking the mask: A look at the process by which authentic leaders impact follower attitudes and behaviors. The Leadership Quarterly, 15, 801-823. https://doi.org/10.1016/j.leaqua.2004.09.003

Axtell, C., Holman, D., Unsworth, K., Wall, T., Waterson, P., \& Harrington, E. (2000). Shopfloor innovation: Facilitating the suggestion and implementation of ideas. Journal of Occupational and Organizational Psychology, 73, 265-285. https://doi.org/10.1348/096317900167029

Baas, M., De Dreu, C. K., \& Nijstad, B. A. (2008). A meta-analysis of 25 years of moodcreativity research: Hedonic tone, activation, or regulatory focus? Psychological bulletin, $134,779-806$.

Baer, J. (1998). The case for domain specificity of creativity. Creativity Research Journal, 11, 173-177. https://doi.org/10.1207/s15326934crj1102_7 
Baer, J., \& Kaufman, J. C. (2008). Gender differences in creativity. The Journal of Creative Behavior, 42, 75-105. https://doi.org/10.1002/j.2162-6057.2008.tb01289.x

Baer, M., Oldham, G. R., \& Cummings, A. (2003). Rewarding creativity: when does it really matter? The Leadership Quarterly, 14, 569-586. https://doi.org/10.1016/S10489843(03)00052-3

Bandura, A. (1986). Social foundations of thought and action: A social cognitive theory. Englewood Cliffs, NJ: Prentice-Hall.

Bandura, A. (1997). Self-efficacy: The exercise of control. New York: Freeman.

Banks, G. C., Gooty, J., Ross, R. L., Williams, C. E., \& Harrington, N. T. (2018). Construct redundancy in leader behaviors: A review and agenda for the future. The Leadership Quarterly, 29, 236-251. https://doi.org/10.1016/j.leaqua.2017.12.005

Banks, G. C., McCauley, K. D., Gardner, W. L., \& Guler, C. E. (2016). A meta-analytic review of authentic and transformational leadership: A test for redundancy. The Leadership Quarterly, 27, 634-652. https://doi.org/10.1016/j.leaqua.2016.02.006

Baron, L., \& Parent, É. (2015). Developing authentic leadership within a training context: Three phenomena supporting the individual development process. Journal of Leadership \& Organizational Studies, 22, 37-53. https://doi.org/10.1177/1548051813519501

Bass, B. M. (1985). Leadership and performance beyond expectations. New York: Simon \& Schuster.

Bass, B. M., \& Avolio, B. J. (1993). Transformational leadership: A response to critiques. In M. M. Chemers \& R. Ayman (Eds.), Leadership theory and research: Perspectives and directions (pp. 49-80). San Diego, CA, US: Academic Press.

Behrens, J., \& Patzelt, H. (2018). Incentives, resources and combinations of innovation radicalness and innovation speed. British Journal of Management, 29, 691-711. https://doi.org/10.1111/1467-8551.12265 
Blau, P. M. (1964). Exchange and power in social life. New York: John Wiley \& Sons, Ltd.

Borenstein, M., Hedges, L. V., Higgins, J. P., \& Rothstein, H. R. (2011). Introduction to meta-analysis. Chichester: John Wiley \& Sons, Ltd.

Brown, M. E., Trevino, L. K., \& Harrison, D. A. (2005). Ethical leadership: A social learning perspective for construct development and testing. Organizational Behavior and Human Decision Processes, 97, 117-134. https://doi.org/10.1016/j.

Burnett, M. F., Chiaburu, D. S., Shapiro, D. L., \& Li, N. (2015). Revisiting how and when perceived organizational support enhances taking charge: An inverted U-shaped perspective. Journal of Management, 41, 1805-1826.

https://doi.org/10.1177/0149206313493324

Cai, W., Lysova, E. I., Khapova, S. N., \& Bossink, B. A. (2019). Does entrepreneurial leadership foster creativity among employees and teams? The mediating role of creative efficacy beliefs. Journal of Business and Psychology, 34, 203-217.

https://doi.org/10.1007/s10869-018-9536-y

Chen, M. H. (2007). Entrepreneurial leadership and new ventures: Creativity in entrepreneurial teams. Creativity and Innovation Management, 16, 239-249. https://doi.org/10.1111/j.1467-8691.2007.00439.x

Chen, G., Farh, J.-L., Campbell-Bush, E. M., Wu, Z., \& Wu, X. (2013). Teams as innovative systems: Multilevel motivational antecedents of innovation in R\&D teams. Journal of Applied Psychology, 98, 1018-1027. https://doi.org/10.1037/a0032663

Cheng, B. S., Chou, L. F., Wu, T. Y., Huang, M. P., \& Farh, J. L. (2004). Paternalistic leadership and subordinate responses: Establishing a leadership model in Chinese organizations. Asian Journal of Social Psychology, 7, 89-117.

https://doi.org/10.1111/j.1467-839X.2004.00137.x 
Chi, S. C. S., \& Liang, S. G. (2013). When do subordinates' emotion-regulation strategies matter? Abusive supervision, subordinates' emotional exhaustion, and work withdrawal. The Leadership Quarterly, 24, 125-137. https://doi.org/10.1016/j.leaqua.2012.08.006

Chow, I. H. S., Lo, T. W. C., Sha, Z., \& Hong, J. (2006). The impact of developmental experience, empowerment, and organizational support on catering service staff performance. International Journal of Hospitality Management, 25, 478-495. https://doi.org/10.1016/j.ijhm.2005.03.002

Chuang, C. H., Jackson, S. E., \& Jiang, Y. (2016). Can knowledge-intensive teamwork be managed? Examining the roles of HRM systems, leadership, and tacit knowledge. Journal of Management, 42, 524-554. https://doi.org/10.1177/0149206313478189

Cole, M. S., Walter, F., Bedeian, A. G., \& O’Boyle, E. H. (2012). Job burnout and employee engagement: A meta-analytic examination of construct proliferation. Journal of Management, 38, 1550-1581. https://doi.org/10.1177/0149206311415252

Cole, J. R., \& Zuckerman, H. (1987). Marriage, motherhood and research performance in science. Scientific American, 256, 119-125.

Deci, E., \& Ryan, R. (2000). The "what" and "why" of goal pursuits: Human needs and the self-determination of behavior. Psychological Inquiry, 11, 227-268. https://doi.org/10.1207/S15327965PLI1104_01

De Hoogh, A. H., \& Den Hartog, D. N. (2008). Ethical and despotic leadership, relationships with leader's social responsibility, top management team effectiveness and subordinates' optimism: A multi-method study. The Leadership Quarterly, 19, 297-311. https://doi.org/10.1016/j.leaqua.2008.03.002

de Vries, R. E. (2012). Personality predictors of leadership styles and the self-other agreement problem. The Leadership Quarterly, 23, 809-821. https://doi.org/10.1016/j.leaqua.2012.03.002 
Deci, E. L., \& Ryan, R. M. (1987). The support of autonomy and the control of behavior. Journal of Personality and Social Psychology, 53, 1024-1037. http://dx.doi.org/10.1037/0022-3514.53.6.1024

Dedahanov, A. T., Lee, D. H., Rhee, J. \& Yoon, J. (2016). Entrepreneur's paternalistic leadership style and creativity: The mediating role of employee voice. Management Decision, 54, 2310-2324. https://doi.org/10.1108/MD-11-2015-0537

Den Hartog, D. N., House, R. J., Hanges, P. J., Ruiz-Quintanilla, S. A., Dorfman, P. W., Abdalla, I. A., et al.,. (1999). Culture specific and cross-culturally generalizable implicit leadership theories: Are attributes of charismatic/transformational leadership universally endorsed? The Leadership Quarterly, 10, 219-256. https://doi.org/10.1016/S1048$\underline{9843(99) 00018-1}$

Derue, D. S., Nahrgang, J. D., Wellman, N. E. D., \& Humphrey, S. E. (2011). Trait and behavioral theories of leadership: An integration and meta- analytic test of their relative validity. Personnel Psychology, 64, 7-52. https://doi.org/10.1111/j.1744$6570.2010 .01201 . x$

Donate, M. J., \& de Pablo, J. D. S. (2015). The role of knowledge-oriented leadership in knowledge management practices and innovation. Journal of Business Research, 68, 360-370. https://doi.org/10.1016/j.jbusres.2014.06.022

Dorfman, P., Sully de Luque, M., Hanges, P., \& Javidan, M. (2010). Strategic leadership across cultures: The new GLOBE multinational study, Academy of Management Annual Meeting, Montreal, Canada.

Edmondson, A. (1999). Psychological safety and learning behavior in work teams. Administrative Science Quarterly, 44, 350-383. https://doi.org/10.2307/2666999 
Ehrhart, M. G. (2004). Leadership and procedural justice climate as antecedents of unit- level organizational citizenship behavior. Personnel Psychology, 57, 61-94. https://doi.org/10.1111/j.1744-6570.2004.tb02484.x

Farh, J. L. \& Cheng. B. S. (2000). A cultural analysis of paternalistic leadership in Chinese organizations. In J. T. Li, A. S. Tsui, \& E. Weldon (Eds.), Management and organizations in the Chinese context (pp. 84-127). London, UK: Macmillan Press Ltd.

Fischer, T., Dietz, J., \& Antonakis, J. (2017). Leadership process models: A review and synthesis. Journal of Management, 43, 1726-1753.

https://doi.org/10.1177/0149206316682830

Furnham, A., Fong, G., \& Martin, N. (1999). Sex and cross-cultural differences in the estimated multi-faceted intelligence quotient score for self, parents and siblings. Personality and Individual Differences, 26, 1025-1034. https://doi.org/10.1016/S01918869(98)00201-3

Gouldner AW. (1960). The norm of reciprocity: A preliminary statement. American Sociological Review, 25, 161-178. https://doi.org/10.2307/2092623

Graen, G. B., \& Cashman, J.F. (1975). A role-making model of leadership in formal organizations: A developmental approach. In J.G. Hunt \& L.L Larson (Eds.), Leadership Frontiers (pp. 143-165). Kent, Ohio: Kent State University Press.

Graen, G. B., \& Uhl-Bien, M. (1995). Relationship-based approach to leadership: Development of leader-member exchange (LMX) theory of leadership over 25 years: Applying a multi-level multi-domain perspective. The Leadership Quarterly, 6, 219-247. https://doi.org/10.1016/1048-9843(95)90036-5

Gu, J., Song, J., \& Wu, J. (2016). Abusive supervision and employee creativity in China: Departmental identification as mediator and face as moderator. Leadership \& 
Organization Development Journal, 37, 1187-1204. https://doi.org/10.1108/LODJ-022015-0021

Hale, J. R., \& Fields, D. L. (2007). Exploring servant leadership across cultures: A study of followers in Ghana and the USA. Leadership, 3, 397-417. https://doi.org/10.1177/1742715007082964

Hammond, M. M., Neff, N. L., Farr, J. L., Schwall, A. R., \& Zhao, X. (2011). Predictors of individual-level innovation at work: A meta-analysis. Psychology of Aesthetics, Creativity, and the Arts, 5, 90-105. http://dx.doi.org/10.1037/a0018556

Harris, T. B., Li, N., Boswell, W. R., Zhang, X. A., \& Xie, Z. (2014). Getting what's new from newcomers: Empowering leadership, creativity, and adjustment in the socialization context. Personnel Psychology, 67, 567-604. https://doi.org/10.1111/peps.12053

Hiller, N. J., Sin, H-P, Ponnapalli, A., \& Novelli, S. O. (2018). Benevolence and authority as WEIRDly unfamiliar: A multi-language meta-analysis of paternalistic leadership behaviors from 152 studies. The Leadership Quarterly, 10, 1016/j.leaqua.2018.11.003.

Hoch, J. E., Bommer, W. H., Dulebohn, J. H., \& Wu, D. (2018). Do ethical, authentic, and servant leadership explain variance above and beyond transformational leadership? A meta-analysis. Journal of Management, 44, 501-529. https://doi.org/10.1177/0149206316665461

Hofstede, G. (2001). Culture's consequences: Comparing values, behaviors, institutions and organizations across nations. New York: Sage publications.

Honig-Haftel, S., \& Martin, L. R. (1993). The effectiveness of reward systems on innovative output: An empirical analysis. Small Business Economics, 5, 261-269.

House, R. J., \& Aditya, R. N. (1997). The social scientific study of leadership: Quo vadis? Journal of Management, 23, 409-473. https://doi.org/10.1177/014920639702300306 
House, R., Javidan, M., Hanges, P., \& Dorfman, P. (2002). Understanding cultures and implicit leadership theories across the globe: an introduction to project GLOBE. Journal of World Business, 37, 3-10. https://doi.org/10.1016/S1090-9516(01)00069-4

Hughes, D. J. (2018). Psychometric validity: Establishing the accuracy and appropriateness of psychometric measures. In P. Irwing, T. Booth, \& D. J. Hughes (Eds.). The Wiley handbook of psychometric testing: A multidisciplinary approach to survey, scale and test development. Chichester, UK: Wiley.

Hughes, D. J., Furnham, A., \& Batey, M. (2013). The structure and personality predictors of self-rated creativity. Thinking Skills and Creativity, 9, 76-84. https://doi.org/10.1016/j.tsc.2012.10.001

Hughes, D. J., Lee, A., Tian, A. W., Newman, A., \& Legood, A. (2018). Leadership, creativity, and innovation: A critical review and practical recommendations. The Leadership Quarterly, 29, 549-569. https://doi.org/10.1016/j.leaqua.2018.03.001

Hunter, S. T., Bedell-Avers, K. E., \& Mumford, M. D. (2007). The typical leadership study: Assumptions, implications, and potential remedies. The Leadership Quarterly, 18, 435446. https://doi.org/10.1016/j.leaqua.2007.07.001

Hunter, J. E., \& Schmidt, F. L. (1990). Dichotomization of continuous variables: The implications for meta-analysis. Journal of Applied Psychology, 75, 334-349. https://doi.org/10.1037/0021-9010.75.3.334

Hunter, J. E., \& Schmidt, F. L. (2015) Methods of meta-analysis: Correcting error and bias in research findings, Newbury Park, CA: Sage publishing

Ilies, R., Morgeson, F. P., \& Nahrgang, J. D. (2005). Authentic leadership and eudaemonic well-being: Understanding leader-follower outcomes. The Leadership Quarterly, 16, 373-394. https://doi.org/10.1016/j.leaqua.2005.03.002 
Janssen, O. (2000). Job demands, perceptions of effort- reward fairness and innovative work behavior. Journal of Occupational and Organizational Psychology, 73, 287-302. https://doi.org/ 10.1348/096317900167038

Jaussi, K. S., \& Dionne, S. D. (2003). Leading for creativity: The role of unconventional leader behavior. The Leadership Quarterly, 14, 475-498. https://doi.org/10.1016/S10489843(03)00048-1

Javidan, M., House, R. J., Dorfman, P. W., Hanges, P. J., \& De Luque, M. S. (2006). Conceptualizing and measuring cultures and their consequences: A comparative review of GLOBE's and Hofstede's approaches. Journal of International Business Studies, 37, 897-914. https://doi.org/10.1057/palgrave.jibs.8400234

Javed, B., Khan, A. A., Bashir, S., \& Arjoon, S. (2017). Impact of ethical leadership on creativity: The role of psychological empowerment. Current Issues in Tourism, 20, 839851. https://doi.org/ 10.1080/13683500.2016.1188894

Johnson, J. W. (2000). A heuristic method for estimating the relative weight of predictor variables in multiple regression. Multivariate Behavioral Research, 35, 1-19. https://doi.org/10.1207/S15327906MBR3501_1

Johnson, J. W., \& LeBreton, J. M. (2004). History and use of relative importance indices in organizational research. Organizational Research Methods, 7(3), 238-257. https://doi.org/10.1177/1094428104266510

Jung, D. I., Chow, C., \& Wu, A. (2003). The role of transformational leadership in enhancing organizational innovation: Hypotheses and some preliminary findings. The Leadership Quarterly, 14, 525-544. https://doi.org/10.1016/S1048-9843(03)00050-X

Kanungo, R. N. (2001). Ethical values of transactional and transformational leaders. Canadian Journal of Administrative Sciences, 18, 257-265. https://doi.org/10.1111/j.1936-4490.2001.tb00261.x 
Kark, R., Van Dijk, D., \& Vashdi, D. R. (2018). Motivated or demotivated to be creative: The role of self- regulatory focus in transformational and transactional leadership processes. Applied Psychology, 67, 186-224. https://doi.org/10.1111/apps.12122

Kaufman, J. C. (2006). Self- reported differences in creativity by ethnicity and gender. Applied Cognitive Psychology: The Official Journal of the Society for Applied Research in Memory and Cognition, 20, 1065-1082. https://doi.org/10.1002/acp.1255

Kehr, H. M. (2004). Integrating implicit motives, explicit motives, and perceived abilities: The compensatory model of work motivation and volition. Academy of Management Review, 29, 479-499. https://doi.org/10.5465/amr.2004.13670963

Keller, R. T. (2006). Transformational leadership, initiating structure, and substitutes for leadership: A longitudinal study of research and development project team performance. Journal of Applied Psychology, 91, 202-210. http://dx.doi.org/10.1037/00219010.91.1.202

Kiazad, K., Restubog, S. L. D., Zagenczyk, T. J., Kiewitz, C., \& Tang, R. L. (2010). In pursuit of power: The role of authoritarian leadership in the relationship between supervisors' Machiavellianism and subordinates' perceptions of abusive supervisory behavior. Journal of Research in Personality, 44, 512-519. https://doi.org/10.1016/j.jrp.2010.06.004

Kiewitz, C., Restubog, S. L. D., Shoss, M. K., Garcia, P. R. J. M., \& Tang, R. L. (2016). Suffering in silence: Investigating the role of fear in the relationship between abusive supervision and defensive silence. Journal of Applied Psychology, 101, 731-742. https://psycnet.apa.org/doi/10.1037/apl0000074

Kim, M., Beehr, T. A., \& Prewett, M. S. (2018). Employee responses to empowering leadership: A meta-analysis. Journal of Leadership \& Organizational Studies, 25, 257 276. https://doi.org/10.1177/1548051817750538 
Kim, J. G., \& Lee, S. Y. (2011). Effects of transformational and transactional leadership on employees' creative behaviour: mediating effects of work motivation and job satisfaction. Asian Journal of Technology Innovation, 19(2), 233-247. https://doi.org/10.1080/19761597.2011.632590

Kirkman, B. L., Chen, G., Farh, J. L., Chen, Z. X., \& Lowe, K. B. (2009). Individual power distance orientation and follower reactions to transformational leaders: A cross-level, cross-cultural examination. Academy of Management Journal, 52, 744-764. https://doi.org/10.5465/amj.2009.43669971

Kirkman, B. L., \& Rosen, B. (1999). Beyond self-management: Antecedents and consequences of team empowerment. Academy of Management journal, 42, 58-74. https://doi.org/10.5465/256874

Klijn, M., \& Tomic, W. (2010). A review of creativity within organizations from a psychological perspective. Journal of Management Development, 29, 322-343. https://doi.org/10.1108/02621711011039141

Kurtessis, J. N., Eisenberger, R., Ford, M. T., Buffardi, L. C., Stewart, K. A., \& Adis, C. S. (2017). Perceived organizational support: A meta-analytic evaluation of organizational support theory. Journal of Management, 43, 1854-1884. https://doi.org/10.1177/0149206315575554

LeBreton, J. M., \& Tonidandel, S. (2008). Multivariate relative importance: Extending relative weight analysis to multivariate criterion spaces. Journal of Applied Psychology, 93, 329-345. http://dx.doi.org/10.1037/0021-9010.93.2.329

Lee, J. (2008). Effects of leadership and leader-member exchange on innovativeness. Journal of Managerial Psychology, 23, 670-687. https://doi.org/10.1108/02683940810894747 
Lee, A., Lyubovnikova, J., Tian, A. W., \& Knight, C. (2019). Servant leadership: A metaanalytic examination of incremental contribution, moderation, and mediation. Journal of Occupational and Organizational Psychology. https://doi.org/10.1111/joop.12265

Lee, A., Martin, R., Thomas, G., Guillaume, Y., \& Maio, G. R. (2015). Conceptualizing leadership perceptions as attitudes: Using attitude theory to further understand the leadership process. The Leadership Quarterly, 26, 910-934. https://doi.org/10.1016/j.leaqua.2015.10.003

Lee, A., Willis, S., \& Tian, A. W. (2018). Empowering leadership: A meta- analytic examination of incremental contribution, mediation, and moderation. Journal of Organizational Behavior, 39, 306-325. https://doi.org/10.1002/job.2220

Lemoine, G. J., Hartnell, C. A., \& Leroy, H. (2019). Taking stock of moral approaches to leadership: An integrative review of ethical, authentic, and servant leadership. Academy of Management Annals, 13, 148-187. https://doi.org/10.5465/annals.2016.0121

Li, M., \& Zhang, P. (2016). Stimulating learning by empowering leadership: Can we achieve cross-level creativity simultaneously? Leadership \& Organization Development Journal, 37, 1168-1186. https://doi.org/10.1108/LODJ-01-2015-0007

Liao, S. H., Fei, W. C., \& Chen, C. C. (2007). Knowledge sharing, absorptive capacity and innovation capability: An empirical study of Taiwan's knowledge-intensive industries. Journal of Information Science, 33, 340-359. https://doi.org/10.1177/0165551506070739

Liao, H., Liu, D., \& Loi, R. (2010). Looking at both sides of the social exchange coin: A social cognitive perspective on the joint effects of relationship quality and differentiation on creativity. Academy of Management Journal, 53, 1090-1109. https://doi.org/10.5465/amj.2010.54533207

Liden, R. C., Sparrowe, R., \& Wayne, S. J. 1997. Leader-member exchange theory: The past and potential for the future. Research in Personnel and Human Resources Management, 
$15,47-119$.

Lin, W., Ma, J., Zhang, Q., Li, J. C., \& Jiang, F. (2018). How is benevolent leadership linked to employee creativity? The mediating role of leader-member exchange and the moderating role of power distance orientation. Journal of Business Ethics, 152, 10991115. https://doi.org/10.1007/s10551-016-3314-4

Magadley, W., \& Birdi, K. (2012). Two sides of the innovation coin? An empirical investigation of the relative correlates of idea generation and idea implementation. International Journal of Innovation Management, 16, 1-28. https://doi.org/10.1142/S1363919611003386

Mainemelis, C., Kark, R., \& Epitropaki, O. (2015). Creative leadership: A multi-context conceptualization. Academy of Management Annals, 9, 393-482. https://doi.org/10.5465/19416520.2015.1024502

Malik, M. A. R., Butt, A. N., \& Choi, J. N. (2015). Rewards and employee creative performance: Moderating effects of creative self- efficacy, reward importance, and locus of control. Journal of Organizational Behavior, 36, 59-74. https://doi.org/10.1002/job.1943

Martin, R., Guillaume, Y., Thomas, G., Lee, A. \& Epitropaki, O. (2016). Leader-member exchange (LMX) and performance: A meta-analytic review. Personnel Psychology, 69, 67-121. https://doi.org/10.1111/peps. 12100

Meng, Y., Tan, J., \& Li, J. (2017). Abusive supervision by academic supervisors and postgraduate research students' creativity: The mediating role of leader-member exchange and intrinsic motivation. International Journal of Leadership in Education, 20, 605-617. https://doi.org/ 10.1080/13603124.2017.1304576

Miao, Q., Newman, A., Schwarz, G., \& Xu, L. (2013). Participative leadership and the organizational commitment of civil servants in china: The mediating effects of trust in 
supervisor. British Journal of Management, 24, S76-S92. https://doi.org/10.1111/14678551.12025

Miles, I. (2008). Knowledge-intensive services. Manchester Institute for Innovation Research, University of Manchester, UK.

Naseer, S., Raja, U., Syed, F., Donia, M. B. L., \& Darr, W. (2016). Perils of being close to a bad leader in a bad environment: Exploring the combined effects of despotic leadership, leader member exchange, and perceived organizational politics on behaviors. The Leadership Quarterly, 27, 14-33. https://doi.org/10.1016/j.leaqua.2015.09.005

Newman, A., Tse, H. M., Schwarz, G., \& Nielsen, I. (2018). The effects of employees' creative self-efficacy on innovative behavior: The role of entrepreneurial leadership. Journal of Business Research, 89, 1-9. https://doi.org/10.1016/j.jbusres.2018.04.001

Ng, T. W., \& Feldman, D. C. (2015). Ethical leadership: Meta-analytic evidence of criterionrelated and incremental validity. Journal of Applied Psychology, 100, 948 - 965. https://doi.org/10.1037/a0038246

Ng, K.-Y., Koh, C., Ang, S., Kennedy, J. C., \& Chan, K.-Y. (2011). Rating leniency and halo in multisource feedback ratings: Testing cultural assumptions of power distance and individualism-collectivism. Journal of Applied Psychology, 96, 1033-1044. http://dx.doi.org/10.1037/a0023368

Oldham, G., \& Cummings, A. (1996). Employee creativity: Personal and contextual factors at work. Academy of Management Journal, 39, 607-634. https://doi.org/10.2307/256657

Pan, W., Sun, L. Y., \& Chow, I. H. S. (2012). Leader-member exchange and employee creativity: Test of a multilevel moderated mediation model. Human Performance, 25, 432-451. https://doi.org/10.1080/08959285.2012.721833 
Parker, S. K., Wall, T. D., \& Jackson, P. R. (1997). "That's not my job": Developing flexible employee work orientations. Academy of Management Journal, 40, 899-929. https://doi.org/10.5465/256952

Pellegrini, E. K., \& Scandura, T. A. (2008). Paternalistic leadership: A review and agenda for future research. Journal of Management, 34, 566-593. https://doi.org/10.1177/0149206308316063

Perry-Smith, J. E., \& Mannucci, P. V. (2017). From creativity to innovation: The social network drivers of the four phases of the idea journey. Academy of Management Review, 42, 53-79. https://doi.org/10.5465/amr.2014.0462

Piccolo, R. F., Bono, J. E., Heinitz, K., Rowold, J., Duehr, E., \& Judge, T. A. (2012). The relative predictive impact of complementary leader behaviors: Which matter most? The Leadership Quarterly, 23, 567-581. https://doi.org/10.1016/j.leaqua.2011.12.008

Piirto, J. (1991). Why are there so few? (Creative women: Visual artists, mathematicians, musicians). Roeper Review, 13, 142-147. https://doi.org/10.1080/02783199109553340

Podsakoff, P. M., MacKenzie, S. B., \& Podsakoff, N. P. (2012). Sources of method bias in social science research and recommendations on how to control it. Annual Review of Psychology, 63, 539-569. https://doi.org/10.1146/annurev-psych-120710-100452

Prati, M. L. M., Douglas, C., Ferris, G. R., Ammeter, A. P., \& Buckley, M. R. (2003). Emotional intelligence, leadership effectiveness, and team outcomes. The International Journal of Organizational Analysis, 11, 21-40. https://doi.org/10.1108/eb028961

Owens, B. P., \& Hekman, D. R. (2012). Modeling how to grow: An inductive examination of humble leader behaviors, contingencies, and outcomes. Academy of Management Journal, 55, 787-818. https://doi.org/10.5465/amj.2010.0441 
Rank, J., Pace, V., \& Frese, M. (2004). Three avenues for future research on creativity, innovation, and initiative. Applied Psychology, 53, 518-528. https://doi.org/10.1111/j.1464-0597.2004.00185.x

Rego, A., Sousa, F., Cunha, M. P., Correia, A., \& Saur- Amaral, I. (2007). Leader selfreported emotional intelligence and perceived employee creativity: An exploratory study. Creativity and Innovation Management, 16, 250-264. https://doi.org/10.1111/j.1467$\underline{8691.2007 .00435 . x}$

Reiter-Palmon, R., \& Illies, J. J. (2004). Leadership and creativity: Understanding leadership from a creative problem-solving perspective. The Leadership Quarterly, 15, 55-77. https://doi.org/10.1016/j.leaqua.2003.12.005

Renko, M. (2018), Entrepreneurial Leadership. In J. Antonakis, D.V. Day (Eds.), The nature of leadership (3rd ed. pp. 381-408), Thousand Oaks, CA: Sage Publishing.

Renko, M., Tarabishy, A. E., Carsrud, A. L., \& Brännback, M. (2015). Understanding and measuring entrepreneurial leadership style. Journal of Small Business Management, 53, 54-74. https://doi.org/10.1111/jsbm.12086

Rickards, T., Chen, M. H., \& Moger, S. (2001). Development of a self-report instrument for exploring team factor, leadership and performance relationships. British Journal of Management, 12, 243-250. https://doi.org/10.1111/1467-8551.00197

Rockstuhl, T., Dulebohn, J. H., Ang, S., \& Shore, L. M. (2012). Leader-member exchange (LMX) and culture: A meta-analysis of correlates of LMX across 23 countries. Journal of Applied Psychology, 97, 1097-1130. http://dx.doi.org/10.1037/a0029978

Rosing, K., Frese, M., \& Bausch, A. (2011). Explaining the heterogeneity of the leadershipinnovation relationship: Ambidextrous leadership. The Leadership Quarterly, 22, 956974. https://doi.org/10.1016/j.leaqua.2011.07.014 
Scott, S. G., \& Bruce, R. A. (1994). Determinants of innovative behavior: A path model of individual innovation in the workplace. Academy of Management Journal, 37, 580-607. https://doi.org/10.2307/256701

Schyns, B., \& Schilling, J. (2013). How bad are the effects of bad leaders? A meta-analysis of destructive leadership and its outcomes. The Leadership Quarterly, 24, 138-158. https://doi.org/10.1016/j.leaqua.2012.09.001

Seibert, S. E., Kraimer, M. L., \& Liden, R. C. (2001). A social capital theory of career success. Academy of Management Journal, 44, 219-237. https://doi.org/10.5465/3069452

Shaffer, J. A., DeGeest, D., \& Li, A. (2016). Tackling the problem of construct proliferation: A guide to assessing the discriminant validity of conceptually related constructs. Organizational Research Methods, 19, 80-110. https://doi.org/10.1177/1094428115598239

Shalley, C.E., \& Gilson, L.L. (2004). What leaders need to know: A review of social and contextual factors that can foster or hinder creativity. The Leadership Quarterly, 15, 3353. https://doi.org/10.1016/j.leaqua.2003.12.004

Shin, S. J., \& Zhou, J. (2003). Transformational leadership, conservation, and creativity: Evidence from Korea. The Academy of Management Journal, 46, 703-714. https://doi.org/ 10.2307/30040662

Sosik, J. J., Kahai, S. S., \& Avolio, B. J. (1999). Leadership style, anonymity, and creativity in group decision support systems: The mediating role of optimal flow. Journal of Creative Behavior, 33, 227-256. https://doi.org/10.1002/j.2162-6057.1999.tb01405.x

Srivastava, A., Bartol, K. M., \& Locke, E. A. (2006). Empowering leadership in management teams: Effects on knowledge sharing, efficacy, and performance. Academy of Management Journal, 49, 1239-1251. https://doi.org/10.5465/amj.2006.23478718

Sully de Luque, M., Javidan, M., Hanges, P., \& Dorfman, P. (2011) Leadership across 
societies: Universal and culturally specific leadership behavior effectiveness, Academy of Management Annual Meeting, San Antonio, U.S.

Sun, L. Y., Zhang, Z., Qi, J., \& Chen, Z. (2012). Empowerment and creativity: A cross-level investigation. The Leadership Quarterly, 23, 55-65. https://doi.org/10.1016/j.leaqua.2011.11.005

Tepper, B. J. (2000). Consequences of abusive supervision. Academy of Management Journal, 43, 178-190. https://doi.org/ 10.2307/1556375

Terpstra, D. E., \& Rozell, E. J. (1993). The relationship of staffing practices to organizational level measures of performance. Personnel Psychology, 46, 27-48. https://doi.org/10.1111/j.1744-6570.1993.tb00866.x

Tierney, P., \& Farmer, S. M. (2002). Creative self-efficacy: Its potential antecedents and relationship to creative performance. Academy of Management Journal, 45, 1137-1148. https://doi.org/10.2307/3069429

Tonidandel, S., \& LeBreton, J. M. (2011). Relative importance analysis: A useful supplement to regression analysis. Journal of Business and Psychology, 26, 1-9, https://doi.org/10.1007/s10869-010-9204-3

Turunc, O., Celik, M., Tabak, A., \& Kabak, M. (2010). The impact of transformational leadership and contingent reward leadership styles on innovative behavior: mediating role of leader-member exchange quality. International Journal of Business and Management Studies, 2, 69-79. http://dergipark.org.tr/ijbms/issue/26070/274758

Tyler, T. R., Lind, E. A., \& Huo, Y. J. (2000). Cultural values and authority relations: The psychology of conflict resolution across cultures. Psychology, Public Policy, and Law, 6, 1138-1163. http://dx.doi.org/10.1037/1076-8971.6.4.1138

Van Dyne, L., Jehn, K. A., \& Cummings, A. (2002). Differential effects of strain on two forms of work performance: Individual employee sales and creativity. Journal of 
Organizational Behavior, 23, 57-74. https://doi.org/10.1002/job.127

Van Knippenberg, D., \& Sitkin, S. B. (2013). A critical assessment of charismatictransformational leadership research: Back to the drawing board? The Academy of Management Annals, 7, 1-60. https://doi.org/10.1080/19416520.2013.759433

Von Nordenflycht, A. (2010). What is a professional service firm? Toward a theory and taxonomy of knowledge-intensive firms. Academy of management Review, 35, 155-174. https://doi.org/10.5465/amr.35.1.zok155

Walumbwa F. O., Avolio, B. J., Gardner, W. L., Wernsing, T. S., \& Peterson, S.J. (2008). Authentic leadership: Development and validation of a theory-based measure. Journal of Management, 34, 89-126. https://doi.org/10.1177/0149206307308913

Wang, G., Oh, I.S., Courtright, S.H., \& Colbert, A.E. (2011). Transformational leadership and performance across criteria and levels: A meta-analytic review of 25 years of research. Group and Organization Management, 36, 223-270.

https://doi.org/10.1177/1059601111401017

Wei, F., Yuan, X., \& Di, Y. (2010). Effects of transactional leadership, psychological empowerment and empowerment climate on creative performance of subordinates: A cross-level study. Frontiers of Business Research in China, 4, 29-46. https://doi.org/10.1007/s11782-010-0002-6

Wang, D., Xue, H., \& Su, H. (2010). Influence of work support on employee creativity: An empirical examination in the Peoples Republic of China. African Journal of Business Management, 4, 1546-1553.

Whitener, E. M. (1990). Confusion of confidence intervals and credibility intervals in metaanalysis. Journal of Applied Psychology, 75, 315-321. https://doi.org/10.1037/00219010.75.3.315 
Watts, L. L., Steele, L. M., \& Den Hartog, D. N. (2019) Uncertainty avoidance moderates the relationship between transformational leadership and innovation: A meta-analysis. Journal of International Business Studies, https://doi.org/10.1057/s41267-019-00242-8

Wu, T. Y., \& Hu, C. (2009). Abusive supervision and employee emotional exhaustion: Dispositional antecedents and boundaries. Group \& Organization Management, 34, 143169. https://doi.org/10.1177/1059601108331217

Xu, E., Huang, X., Lam, C. K., \& Miao, Q. (2012). Abusive supervision and work behaviors: The mediating role of LMX. Journal of Organizational Behavior, 33, 531-543. https://doi.org/10.1002/job.768

Yukl, G. (1999). An evaluation of conceptual weaknesses in transformational and charismatic leadership theories. The Leadership Quarterly, 10, 285-305. https://doi.org/10.1016/S1048-9843(99)00013-2

Zhang, X., \& Bartol, K. M. (2010). Linking empowering leadership and employee creativity: The influence of psychological empowerment, intrinsic motivation, and creative process management. Academy of Management Journal, 53, 107-128. https://doi.org/10.5465/AMJ.2010.48037118

Zhou, J., \& George, J. M. (2001). When job dissatisfaction leads to creativity: Encouraging the expression of voice. Academy of Management Journal, 44, 682-696. https://doi.org/10.2307/3069410

Zhou, J., \& Hoever, I. J. (2014). Research on workplace creativity: A review and redirection. Annual Review of Organizational Psychology \& Organizational Behavior, 1, 333-359. https://doi.org/10.1146/annurev-orgpsych-031413-091226

Zhou, J., \& Shalley, C. E. (2003). Research on employee creativity: A critical review and directions for future research. Research in Personnel and Human Resources Management, 22, 165-218. https://doi.org/10.1016/S0742-7301(03)22004-1 
Table 1 Meta-Analytic correlations between leadership styles, creativity and innovation.

\begin{tabular}{|c|c|c|c|c|c|c|c|c|c|c|}
\hline \multirow[b]{2}{*}{ Variable } & \multirow[b]{2}{*}{$k$} & \multicolumn{7}{|c|}{$95 \% \mathrm{CI}$} & \multicolumn{2}{|c|}{$80 \% \mathrm{CV}$} \\
\hline & & $N$ & $r$ & Lower & Upper & $\rho$ & $S D_{\rho}$ & $\% \mathrm{VE}$ & Lower & Upper \\
\hline \multicolumn{11}{|l|}{ Transformational Leadership } \\
\hline Creativity & 55 & 18122 & 0.28 & 0.23 & 0.33 & 0.31 & 0.20 & 7.51 & 0.05 & 0.57 \\
\hline Creativity: Self-rated & 21 & 7483 & 0.32 & 0.23 & 0.41 & 0.36 & 0.22 & 5.61 & 0.08 & 0.64 \\
\hline Creativity: Other-rated & 34 & 11010 & 0.25 & 0.19 & 0.30 & 0.27 & 0.18 & 9.80 & 0.04 & 0.51 \\
\hline Innovation: & 34 & 14043 & 0.26 & 0.21 & 0.31 & 0.29 & 0.16 & 9.30 & 0.08 & 0.50 \\
\hline Innovation: Self-rated & 19 & 9806 & 0.29 & 0.23 & 0.34 & 0.33 & 0.13 & 11.19 & 0.16 & 0.49 \\
\hline Innovation: Other-rated & 16 & 3946 & 0.23 & 0.14 & 0.26 & 0.26 & 0.22 & 8.62 & -0.02 & 0.54 \\
\hline \multicolumn{11}{|l|}{ Transactional Leadership } \\
\hline Creativity & 12 & 5041 & 0.12 & -0.03 & 0.26 & 0.14 & 0.29 & 3.57 & -0.23 & 0.51 \\
\hline Creativity: Self-rated & 4 & 2556 & 0.28 & 0.12 & 0.44 & 0.34 & 0.19 & 5.29 & 0.10 & 0.57 \\
\hline Creativity: Other-Rated & 8 & 2485 & -0.04 & -0.20 & 0.12 & -0.04 & 0.26 & 5.96 & -0.37 & 0.29 \\
\hline Innovation & 11 & 7186 & 0.19 & 0.10 & 0.27 & 0.23 & 0.17 & 7.12 & 0.02 & 0.45 \\
\hline Innovation: Self-rated & 6 & 5746 & 0.20 & 0.10 & 0.30 & 0.24 & 0.14 & 6.53 & 0.06 & 0.43 \\
\hline Innovation: Other-rated & 6 & 1440 & 0.14 & -0.03 & 0.32 & 0.18 & 0.24 & 8.53 & -0.13 & 0.49 \\
\hline \multicolumn{11}{|l|}{ Authentic Leadership } \\
\hline Creativity & 16 & 5088 & 0.42 & 0.34 & 0.51 & 0.47 & 0.18 & 7.32 & 0.24 & 0.71 \\
\hline Creativity: Self-rated & 7 & 2905 & 0.43 & 0.35 & 0.52 & 0.48 & 0.11 & 13.17 & 0.33 & 0.63 \\
\hline Creativity: Other-rated & 9 & 2184 & 0.41 & 0.26 & 0.56 & 0.47 & 0.25 & 5.56 & 0.15 & 0.79 \\
\hline \multicolumn{11}{|l|}{ Servant Leadership } \\
\hline Creativity & 11 & 4490 & 0.34 & 0.21 & 0.47 & 0.38 & 0.25 & 3.83 & 0.06 & 0.70 \\
\hline Creativity: Self-rated & 5 & 2385 & 0.40 & 0.22 & 0.58 & 0.45 & 0.24 & 3.30 & 0.15 & 0.75 \\
\hline Creativity: Other-rated & 6 & 2105 & 0.27 & 0.09 & 0.45 & 0.31 & 0.24 & 5.17 & 0.00 & 0.61 \\
\hline Innovation & 7 & 1491 & 0.30 & 0.18 & 0.42 & 0.34 & 0.18 & 13.87 & 0.11 & 0.56 \\
\hline Innovation: Self-rated & 4 & 811 & 0.40 & 0.27 & 0.54 & 0.46 & 0.16 & 16.16 & 0.26 & 0.66 \\
\hline
\end{tabular}




\begin{tabular}{|c|c|c|c|c|c|c|c|c|c|c|}
\hline \multirow[b]{2}{*}{ Variable } & \multirow[b]{2}{*}{$k$} & \multicolumn{7}{|c|}{$95 \% \mathrm{CI}$} & \multicolumn{2}{|c|}{$80 \% \mathrm{CV}$} \\
\hline & & $N$ & $r$ & Lower & Upper & $\rho$ & $S D_{\rho}$ & $\% \mathrm{VE}$ & Lower & Upper \\
\hline Innovation: Other-rated & 3 & 680 & 0.18 & 0.09 & 0.28 & 0.20 & 0.06 & 59.56 & 0.13 & 0.28 \\
\hline \multicolumn{11}{|l|}{ Ethical Leadership } \\
\hline Creativity & 15 & 3982 & 0.31 & 0.24 & 0.39 & 0.36 & 0.14 & 16.16 & 0.18 & 0.55 \\
\hline Creativity: Self-rated & 5 & 1250 & 0.29 & 0.16 & 0.41 & 0.34 & 0.14 & 19.10 & 0.16 & 0.52 \\
\hline Creativity: Other-rated & 10 & 2732 & 0.33 & 0.24 & 0.41 & 0.37 & 0.15 & 15.16 & 0.19 & 0.56 \\
\hline Innovation & 7 & 2349 & 0.24 & 0.16 & 0.32 & 0.28 & 0.12 & 19.76 & 0.12 & 0.44 \\
\hline Innovation: Self-rated & 4 & 1396 & 0.25 & 0.12 & 0.38 & 0.28 & 0.15 & 13.13 & 0.09 & 0.47 \\
\hline Innovation: Other-rated & 3 & 953 & 0.23 & 0.17 & 0.29 & 0.28 & 0.05 & 59.32 & 0.22 & 0.35 \\
\hline \multicolumn{11}{|l|}{ Humble Leadership } \\
\hline Creativity & 4 & 1347 & 0.24 & 0.15 & 0.33 & 0.28 & 0.10 & 27.38 & 0.15 & 0.40 \\
\hline Creativity: Other-rated & 4 & 1347 & 0.24 & 0.15 & 0.33 & 0.28 & 0.10 & 27.38 & 0.15 & 0.40 \\
\hline \multicolumn{11}{|l|}{ Empowering Leadership } \\
\hline Creativity & 22 & 5810 & 0.32 & 0.26 & 0.39 & 0.36 & 0.17 & 11.06 & 0.14 & 0.58 \\
\hline Creativity: Self-rated & 6 & 1174 & 0.40 & 0.31 & 0.50 & 0.44 & 0.12 & 24.01 & 0.29 & 0.59 \\
\hline Creativity: Other-rated & 16 & 2892 & 0.38 & 0.31 & 0.45 & 0.42 & 0.15 & 11.81 & 0.22 & 0.62 \\
\hline Innovation & 9 & 4595 & 0.31 & 0.25 & 0.37 & 0.35 & 0.10 & 16.35 & 0.22 & 0.48 \\
\hline Innovation: Self-rated & 5 & 2450 & 0.37 & 0.30 & 0.44 & 0.43 & 0.08 & 24.88 & 0.33 & 0.53 \\
\hline Innovation: Other-rated & 4 & 2145 & 0.24 & 0.18 & 0.31 & 0.27 & 0.06 & 39.07 & 0.20 & 0.35 \\
\hline \multicolumn{11}{|l|}{ Entrepreneurial Leadership } \\
\hline Creativity & 3 & 820 & 0.40 & 0.27 & 0.54 & 0.47 & 0.11 & 21.02 & 0.32 & 0.62 \\
\hline Innovation & 5 & 1379 & 0.26 & 0.19 & 0.33 & 0.29 & 0.06 & 49.23 & 0.21 & 0.37 \\
\hline \multicolumn{11}{|l|}{ LMX } \\
\hline Creativity & 39 & 11671 & 0.30 & 0.26 & 0.35 & 0.34 & 0.14 & 15.46 & 0.16 & 0.52 \\
\hline Creativity: Self-rated & 16 & 4846 & 0.36 & 0.31 & 0.42 & 0.41 & 0.12 & 18.68 & 0.26 & 0.56 \\
\hline Creativity: Other-Rated & 27 & 7411 & 0.27 & 0.21 & 0.32 & 0.30 & 0.14 & 17.29 & 0.12 & 0.47 \\
\hline Innovation & 22 & 6449 & 0.27 & 0.22 & 0.31 & 0.31 & 0.10 & 28.67 & 0.18 & 0.43 \\
\hline
\end{tabular}




\begin{tabular}{|c|c|c|c|c|c|c|c|c|c|c|}
\hline \multirow[b]{2}{*}{ Variable } & \multirow[b]{2}{*}{$k$} & \multicolumn{7}{|c|}{$95 \% \mathrm{CI}$} & \multicolumn{2}{|c|}{$80 \% \mathrm{CV}$} \\
\hline & & $N$ & $r$ & Lower & Upper & $\rho$ & $S D_{\rho}$ & $\% \mathrm{VE}$ & Lower & Upper \\
\hline Innovation: Self-rated & 11 & 4257 & 0.29 & 0.22 & 0.36 & 0.35 & 0.11 & 19.34 & 0.20 & 0.49 \\
\hline Innovation: Other-rated & 11 & 2192 & 0.21 & 0.18 & 0.24 & 0.24 & 0.00 & 100.00 & 0.24 & 0.24 \\
\hline \multicolumn{11}{|l|}{ Supportive Leadership } \\
\hline Creativity & 14 & 4261 & 0.21 & 0.13 & 0.29 & 0.24 & 0.18 & 11.05 & 0.01 & 0.47 \\
\hline Creativity: Self-rated & 8 & 2760 & 0.27 & 0.17 & 0.37 & 0.30 & 0.18 & 9.49 & 0.07 & 0.53 \\
\hline Creativity: Other-rated & 7 & 1779 & 0.08 & -0.01 & 0.18 & 0.09 & 0.14 & 23.08 & -0.08 & 0.26 \\
\hline Innovation & 8 & 2770 & 0.31 & 0.24 & 0.38 & 0.36 & 0.12 & 17.60 & 0.20 & 0.51 \\
\hline Innovation: Self-rated & 4 & 1419 & 0.27 & 0.15 & 0.40 & 0.31 & 0.15 & 12.55 & 0.12 & 0.50 \\
\hline Innovation: Other-rated & 4 & 1351 & 0.35 & 0.31 & 0.39 & 0.41 & 0.05 & 60.97 & 0.35 & 0.47 \\
\hline \multicolumn{11}{|l|}{ Benevolent Leadership } \\
\hline Creativity & 6 & 1780 & 0.23 & 0.17 & 0.30 & 0.27 & 0.07 & 42.66 & 0.18 & 0.37 \\
\hline Creativity: Other-rated & 4 & 1206 & 0.20 & 0.15 & 0.26 & 0.23 & 0.00 & 100.00 & 0.23 & 0.23 \\
\hline Innovation & 5 & 1452 & 0.25 & 0.10 & 0.40 & 0.28 & 0.20 & 9.25 & 0.02 & 0.53 \\
\hline Innovation: Self-rated & 3 & 741 & 0.23 & -0.02 & 0.48 & 0.23 & 0.25 & 6.73 & -0.08 & 0.55 \\
\hline \multicolumn{11}{|l|}{ Authoritarian Leadership } \\
\hline Creativity & 11 & 4367 & -0.10 & -0.20 & $-0.00 *$ & -0.13 & 0.18 & 9.07 & -0.36 & 0.11 \\
\hline Creativity: Self-rated & 6 & 1422 & -0.13 & -0.30 & 0.03 & -0.16 & 0.23 & 10.01 & -0.45 & 0.12 \\
\hline Creativity: Other-rated & 5 & 2945 & -0.09 & -0.21 & 0.04 & -0.11 & 0.16 & 8.39 & -0.31 & 0.09 \\
\hline Innovation & 6 & 1619 & -0.13 & -0.22 & -0.03 & -0.15 & 0.11 & 27.70 & -0.29 & -0.01 \\
\hline Innovation: Self-rated & 3 & 742 & -0.24 & -0.33 & -0.14 & -0.25 & 0.08 & 40.98 & -0.35 & -0.15 \\
\hline Innovation: Other-rated & 3 & 877 & -0.04 & -0.09 & 0.01 & -0.05 & 0.00 & 100.00 & -0.05 & -0.05 \\
\hline \multicolumn{11}{|l|}{ Destructive Leadership } \\
\hline Creativity & 14 & 4911 & -0.20 & -0.25 & -0.14 & -0.22 & 0.11 & 21.51 & -0.36 & -0.08 \\
\hline Creativity: Self-rated & 5 & 1494 & -0.24 & -0.30 & -0.19 & -0.26 & 0.06 & 53.19 & -0.33 & -0.19 \\
\hline Creativity: Other-rated & 9 & 3417 & -0.18 & -0.25 & -0.10 & -0.20 & 0.12 & 17.53 & -0.35 & -0.04 \\
\hline
\end{tabular}


Note. Results are corrected for criterion and predictor unreliability. $k=$ number of correlations; $N=$ number of respondents; $r=$ sample weighted mean correlation; $\rho=$ corrected population correlation; $S D_{\rho}=$ standard deviation of the corrected population correlation; $\% \mathrm{VE}=$ percentage of variance attributed to sampling error in corrected population correlation; 95\% CI $=95 \%$ confidence interval around the sample weighted mean correlation; $80 \% \mathrm{CV}=80 \%$ credibility interval around the corrected population correlation. * Rounded up from -0.0045

Table 2 Meta-Analytic Results for the Relationship Between the Dimensions of Transformational and Transactional Leadership

\begin{tabular}{|c|c|c|c|c|c|c|c|c|c|c|}
\hline \multirow[b]{2}{*}{ Variable } & \multicolumn{8}{|c|}{$95 \% \mathrm{CI}$} & \multicolumn{2}{|c|}{$80 \% \mathrm{CV}$} \\
\hline & $k$ & $N$ & $r$ & Lower & Upper & $\rho$ & $S D_{\rho}$ & $\% \mathrm{VE}$ & Lower & Upper \\
\hline \multicolumn{11}{|l|}{ Transformational - Creativity } \\
\hline Idealized Influence \& Charisma & 7 & 2283 & 0.18 & 0.13 & 0.23 & 0.20 & 0.06 & 54.75 & 0.13 & 0.27 \\
\hline Inspirational Motivation & 4 & 1149 & 0.17 & 0.14 & 0.20 & 0.20 & 0.00 & 100.00 & 0.20 & 0.20 \\
\hline Intellectual Stimulation & 4 & 1174 & 0.18 & 0.06 & 0.31 & 0.22 & 0.13 & 20.88 & 0.05 & 0.38 \\
\hline Individualized Consideration & 5 & 1888 & 0.19 & 0.14 & 0.24 & 0.22 & 0.05 & 53.93 & 0.15 & 0.29 \\
\hline \multicolumn{11}{|l|}{ Transactional - Creativity } \\
\hline Contingent Reward & 5 & 2511 & 0.30 & 0.16 & 0.43 & 0.36 & 0.18 & 7.21 & 0.14 & 0.59 \\
\hline Contingent Reward: Other-rated & 3 & 849 & 0.15 & 0.04 & 0.26 & 0.19 & 0.03 & 83.26 & 0.16 & 0.23 \\
\hline Management by Exception* & 3 & 1085 & -0.01 & -0.05 & 0.03 & -0.01 & 0.00 & 100.0 & -0.01 & -0.01 \\
\hline \multicolumn{11}{|l|}{ Transactional - Innovation } \\
\hline Contingent Reward & 5 & 4349 & 0.25 & 0.23 & 0.26 & 0.30 & 0.00 & 100.00 & 0.30 & 0.30 \\
\hline Contingent Reward: Other-rated & 3 & 1049 & 0.26 & 0.23 & 0.30 & 0.33 & 0.00 & 100.00 & 0.33 & 0.33 \\
\hline
\end{tabular}

Note. Results are corrected for criterion and predictor unreliability. $k=$ number of correlations; $N=$ number of respondents; $r=$ sample weighted mean correlation; $\rho=$ corrected population correlation; $S D_{\rho}=$ standard deviation of the corrected population correlation; $\%$ VE $=$ percentage of variance attributed to sampling error in corrected population correlation; $95 \% \mathrm{CI}=95 \%$ confidence interval around the sample weighted mean correlation; $80 \% \mathrm{CV}=80 \%$ credibility interval around the corrected population correlation.

*Due to lack of primary studies, it was not possible to examine management by exception passive and active or laissez faire. 
Table 3- Moderation Analyses

\begin{tabular}{|c|c|c|c|c|c|c|c|c|c|c|c|}
\hline Variable & $\boldsymbol{k}$ & $N$ & $r$ & $\boldsymbol{\beta}$ & s.d. & $\begin{array}{l}95 \%- \\
\text { CI- } \\
\text { LL }\end{array}$ & $\begin{array}{l}95 \%- \\
\text { CI- } \\
\text { UL }\end{array}$ & $\begin{array}{l}\text { z- } \\
\text { value }\end{array}$ & $\begin{array}{l}p \text { - } \\
\text { value }\end{array}$ & $\mathbf{T}^{2}$ & Moderator effect present? \\
\hline \multicolumn{12}{|c|}{ Published vs Unpublished Studies } \\
\hline $\begin{array}{l}\text { Transformational - } \\
\text { creativity }\end{array}$ & 55 & 18122 & .27 & -.03 & .07 & -.17 & .11 & -.44 & .66 & .05 & No \\
\hline $\begin{array}{l}\text { Transformational - } \\
\text { innovation }\end{array}$ & 33 & 10863 & .28 & -.01 & .09 & -.19 & .17 & -.14 & .89 & .03 & No \\
\hline LMX - creativity & 39 & 11671 & .32 & -.05 & .08 & -.21 & .11 & -.58 & .56 & .02 & No \\
\hline Empowering - creativity & 22 & 5810 & .35 & .02 & .15 & -.26 & .31 & .15 & .89 & .03 & No \\
\hline \multicolumn{12}{|c|}{ Common-source vs non-common source ratings of outcome } \\
\hline $\begin{array}{l}\text { Transformational - } \\
\text { creativity }\end{array}$ & 55 & 18122 & .27 & -.12 & .06 & -.24 & -.00 & -2.04 & .04 & .04 & $\begin{array}{l}\text { Yes, the correlation is smaller } \\
\text { when the data is based on non- } \\
\text { common source data. }\end{array}$ \\
\hline $\begin{array}{l}\text { Transformational - } \\
\text { innovation }\end{array}$ & 33 & 10863 & .27 & -.14 & .07 & -.27 & -.01 & -2.07 & .04 & .03 & $\begin{array}{l}\text { Yes, the correlation is smaller } \\
\text { when the data is based on non- } \\
\text { common source data. }\end{array}$ \\
\hline Transactional - creativity & 12 & 5041 & .10 & -.21 & .15 & -.50 & .08 & -1.40 & .16 & .06 & No \\
\hline Transactional - innovation & 8 & 3062 & .90 & -.20 & .19 & -.58 & .18 & -1.04 & .30 & .07 & No \\
\hline LMX - creativity & 39 & 11671 & .32 & -.11 & -.05 & -.21 & -.00 & -2.06 & .04 & .02 & $\begin{array}{l}\text { Yes, the correlation is smaller } \\
\text { when the data is based on non- } \\
\text { common source data. }\end{array}$ \\
\hline LMX - innovation & 21 & 6112 & .26 & -.09 & .06 & -.20 & .02 & -1.57 & .12 & .01 & No \\
\hline Authentic - creativity & 16 & 5088 & .44 & .02 & .12 & -.22 & .25 & .13 & .90 & .05 & No \\
\hline Benevolent - creativity & 6 & 1780 & .25 & -.11 & .09 & -.28 & .05 & -1.33 & .18 & .01 & No \\
\hline
\end{tabular}




\begin{tabular}{|c|c|c|c|c|c|c|c|c|c|c|c|}
\hline Variable & $\boldsymbol{k}$ & $N$ & $r$ & $\boldsymbol{\beta}$ & s.d. & $\begin{array}{l}\text { 95\%- } \\
\text { CI- } \\
\text { LL } \\
\end{array}$ & $\begin{array}{l}\text { 95\%- } \\
\text { CI- } \\
\text { UL } \\
\end{array}$ & $\begin{array}{l}\text { z- } \\
\text { value }\end{array}$ & $\begin{array}{l}p \text { - } \\
\text { value }\end{array}$ & $\mathbf{T}^{2}$ & Moderator effect present? \\
\hline Empowering - creativity & 22 & 5810 & .35 & -.13 & .09 & -.31 & .05 & -1.49 & .14 & .03 & No \\
\hline Empowering - innovation & 7 & 3727 & .37 & -.24 & .10 & -.43 & -.04 & -2.40 & .02 & .01 & $\begin{array}{l}\text { Yes, the correlation is smaller } \\
\text { when the data is based on non- } \\
\text { common source data. }\end{array}$ \\
\hline Servant - creativity & 11 & 4490 & .26 & -.07 & .19 & -.41 & .29 & -.35 & .72 & .08 & No \\
\hline Servant - innovation & 7 & 1491 & .28 & .13 & .15 & -.17 & .42 & .85 & .40 & .03 & No \\
\hline Authoritarian - creativity & 11 & 4367 & -.14 & -.01 & .14 & -.28 & .25 & -.10 & .92 & .05 & No \\
\hline Authoritarian - innovation & 6 & 1619 & -.14 & 0.22 & 0.07 & 0.09 & 0.36 & 3.2 & 0.00 & 0.00 & $\begin{array}{l}\text { Yes, the correlation is smaller } \\
\text { when the data is based on non- } \\
\text { common source data. }\end{array}$ \\
\hline Ethical - creativity & 15 & 3982 & .35 & .01 & .10 & -.19 & .21 & .12 & .91 & .03 & No \\
\hline Ethical - innovation & 7 & 2349 & .26 & -.07 & .11 & -.23 & .15 & -.60 & .55 & .02 & No \\
\hline Supportive - creativity & 14 & 4261 & .23 & -.21 & .10 & -.40 & -.02 & -2.20 & .03 & .03 & $\begin{array}{l}\text { Yes, the correlation is smaller } \\
\text { when the data is based on non- } \\
\text { common source data. }\end{array}$ \\
\hline Supportive - innovation & 8 & 2770 & .31 & .06 & .10 & -.13 & .24 & .58 & .56 & .01 & No \\
\hline Destructive - creativity & 13 & 4796 & -.21 & .08 & .08 & -.07 & .24 & 1.02 & .31 & .01 & No \\
\hline \multicolumn{12}{|c|}{ Cross-sectional vs Time-separated studies } \\
\hline $\begin{array}{l}\text { Transformational - } \\
\text { creativity }\end{array}$ & 50 & 16921 & .23 & -.01 & .08 & -.17 & .16 & -.09 & .93 & .05 & No \\
\hline $\begin{array}{l}\text { Transformational - } \\
\text { innovation }\end{array}$ & 33 & 10863 & .27 & -.12 & .08 & -.27 & .03 & -1.59 & .11 & .03 & No \\
\hline LMX - creativity & 39 & 11671 & .32 & -.11 & .06 & -.22 & -.00 & -1.96 & .05 & .37 & $\begin{array}{l}\text { Yes, the correlation is smaller } \\
\text { for time-separated studies }\end{array}$ \\
\hline LMX - innovation & 21 & 6112 & .26 & -.00 & .10 & -.21 & .20 & -.03 & .98 & .01 & No \\
\hline Authentic-creativity & 16 & 5088 & .44 & -.11 & .17 & -.45 & .23 & -.65 & .52 & .07 & No \\
\hline
\end{tabular}




\begin{tabular}{|c|c|c|c|c|c|c|c|c|c|c|c|}
\hline Variable & $\boldsymbol{k}$ & $N$ & $r$ & $\boldsymbol{\beta}$ & s.d. & $\begin{array}{l}95 \%- \\
\text { CI- } \\
\text { LL }\end{array}$ & $\begin{array}{l}95 \%- \\
\text { CI- } \\
\text { UL }\end{array}$ & $\begin{array}{l}z- \\
\text { value }\end{array}$ & $\begin{array}{l}p \text { - } \\
\text { value }\end{array}$ & $\mathbf{T}^{2}$ & Moderator effect present? \\
\hline Empowering - Creativity & 22 & 5810 & .35 & -.06 & .03 & -.13 & -.00 & -1.98 & .05 & .03 & $\begin{array}{l}\text { Yes, the correlation is smaller } \\
\text { for time-separated studies }\end{array}$ \\
\hline Servant - creativity & 11 & 4490 & .26 & -.01 & .20 & -.40 & .38 & -.04 & .97 & .08 & No \\
\hline Destructive - creativity & 13 & 4796 & -.21 & -.01 & .08 & -.16 & .13 & -.19 & .85 & .01 & No \\
\hline \multicolumn{12}{|c|}{ National Culture - Power Distance } \\
\hline $\begin{array}{l}\text { Transformational - } \\
\text { creativity }\end{array}$ & 51 & 16447 & .21 & .00 & .00 & -.00 & .00 & .91 & .36 & .03 & No \\
\hline $\begin{array}{l}\text { Transformational - } \\
\text { innovation }\end{array}$ & 32 & 10542 & .28 & -.00 & .00 & -.00 & .00 & -.01 & .99 & .04 & No \\
\hline Transactional - creativity & 11 & 3938 & .10 & .00 & .00 & -.00 & .01 & 1.19 & .23 & .04 & No \\
\hline Transactional - innovation & 7 & 2741 & .10 & .00 & .01 & -.01 & .02 & .72 & .47 & .13 & No \\
\hline LMX - creativity & 39 & 11671 & .32 & -.00 & .00 & -.00 & .00 & -.35 & .73 & .02 & No \\
\hline LMX - innovation & 19 & 5712 & 0.27 & 0.00 & 0.00 & -0.00 & 0.00 & 1.03 & 0.31 & 0.01 & No \\
\hline Authentic - creativity & 16 & 5088 & .44 & -.00 & .01 & -.01 & .01 & -.32 & .75 & .06 & No \\
\hline Benevolent - creativity & 6 & 1780 & .25 & .00 & .00 & -.01 & .01 & .36 & .72 & .01 & No \\
\hline Empowering - creativity & 21 & 5584 & .30 & -.01 & .00 & -.01 & -.00 & -2.03 & .04 & .02 & $\begin{array}{l}\text { Yes, the higher the power } \\
\text { distance score, the smaller the } \\
\text { correlation. }\end{array}$ \\
\hline Empowering - innovation & 7 & 3727 & .37 & -.00 & .00 & -.01 & .00 & -1.63 & .10 & .02 & No \\
\hline Servant - creativity & 9 & 4121 & .31 & -.00 & .00 & -.01 & .01 & -.39 & .70 & .07 & No \\
\hline Servant - innovation & 5 & 1191 & .34 & .01 & .00 & .01 & .01 & 5.20 & .00 & .00 & $\begin{array}{l}\text { Yes, the higher the power } \\
\text { distance score, the larger the } \\
\text { correlation }\end{array}$ \\
\hline $\begin{array}{l}\text { Authoritarian - creativity } \\
\text { Authoritarian - innovation }\end{array}$ & 9 & 4026 & -.12 & .01 & .01 & -.00 & .02 & 1.37 & .17 & .03 & No \\
\hline Ethical - creativity & 15 & 3982 & .35 & .00 & .00 & -.00 & .01 & .94 & .35 & .03 & No \\
\hline Ethical - innovation & 7 & 2349 & .26 & .01 & .00 & -.00 & .01 & 1.28 & .20 & .01 & No \\
\hline
\end{tabular}




\begin{tabular}{|c|c|c|c|c|c|c|c|c|c|c|c|}
\hline Variable & $\boldsymbol{k}$ & $N$ & $r$ & $\boldsymbol{\beta}$ & s.d. & $\begin{array}{l}\text { 95\%- } \\
\text { CI- } \\
\text { LL }\end{array}$ & $\begin{array}{l}\text { 95\%- } \\
\text { CI- } \\
\text { UL }\end{array}$ & $\begin{array}{l}\text { z- } \\
\text { value }\end{array}$ & $\begin{array}{l}p \text { - } \\
\text { value }\end{array}$ & $\mathbf{T}^{2}$ & Moderator effect present? \\
\hline Supportive - creativity & 11 & 3864 & .15 & .01 & .00 & .00 & .01 & 2.98 & .00 & .01 & $\begin{array}{l}\text { Yes, the higher the power } \\
\text { distance score, the larger the } \\
\text { correlation }\end{array}$ \\
\hline Supportive - innovation & 8 & 2770 & .23 & -.00 & .00 & -.01 & .01 & -.11 & .91 & .02 & No \\
\hline Destructive - creativity & 13 & 4796 & -.21 & -.00 & .00 & -.01 & .00 & -.20 & .83 & .01 & No \\
\hline \multicolumn{12}{|c|}{ Industry Knowledge Intensity } \\
\hline $\begin{array}{l}\text { Transformational - } \\
\text { creativity }\end{array}$ & 38 & 12561 & .26 & .01 & .09 & -.16 & .18 & .11 & .91 & .03 & No \\
\hline $\begin{array}{l}\text { Transformational - } \\
\text { innovation }\end{array}$ & 29 & 10501 & .26 & -.02 & .09 & -.19 & .16 & -.18 & .86 & .04 & No \\
\hline Transactional - creativity & 10 & 3779 & 0.05 & 0.18 & 0.16 & -0.19 & 0.54 & 0.95 & 0.34 & 0.05 & No \\
\hline LMX - creativity & 33 & 9462 & .32 & .05 & .08 & -.11 & .20 & .61 & .54 & .02 & No \\
\hline LMX - innovation & 21 & 6112 & 0.26 & -.24 & 0.06 & -0.36 & -0.13 & -4.02 & 0.00 & 0.01 & $\begin{array}{l}\text { Yes, the correlation is smaller } \\
\text { in knowledge intensive } \\
\text { industries }\end{array}$ \\
\hline Empowering - creativity & 21 & 5358 & .35 & -.06 & .10 & -.25 & .13 & -.60 & .55 & .04 & No \\
\hline Authentic - creativity & 12 & 3787 & .41 & -.31 & .16 & -.63 & .01 & -1.89 & .06 & .07 & No \\
\hline Supportive - creativity & 10 & 3051 & .21 & -.16 & .13 & -.42 & .11 & -1.17 & .24 & .03 & No \\
\hline Supportive - innovation & 8 & 2770 & .31 & -.19 & .09 & -.37 & -.01 & -2.14 & .03 & .01 & $\begin{array}{l}\text { Yes, the correlation is smaller } \\
\text { in knowledge intensive } \\
\text { industries }\end{array}$ \\
\hline Destructive - creativity & 12 & 3847 & -.22 & -.07 & .10 & -.27 & .12 & -.73 & .47 & .02 & No \\
\hline \multicolumn{12}{|l|}{ Follower Gender } \\
\hline $\begin{array}{l}\text { Transformational - } \\
\text { creativity }\end{array}$ & 41 & 12783 & .27 & .00 & .00 & -.00 & .00 & .53 & .59 & .04 & No \\
\hline $\begin{array}{l}\text { Transformational - } \\
\text { innovation }\end{array}$ & 21 & 6545 & .23 & .00 & .00 & -.00 & .01 & .26 & .79 & .04 & No \\
\hline Transactional - creativity & 9 & 3014 & .06 & -.00 & .00 & -.01 & .01 & -.03 & .98 & .04 & No \\
\hline
\end{tabular}




\begin{tabular}{|c|c|c|c|c|c|c|c|c|c|c|c|}
\hline Variable & $k$ & $N$ & $r$ & $\boldsymbol{\beta}$ & s.d. & $\begin{array}{l}\text { 95\%- } \\
\text { CI- } \\
\text { LL }\end{array}$ & $\begin{array}{l}\text { 95\%- } \\
\text { CI- } \\
\text { UL }\end{array}$ & $\begin{array}{l}z- \\
\text { value }\end{array}$ & $\begin{array}{l}p \text { - } \\
\text { value }\end{array}$ & $\mathbf{T}^{2}$ & Moderator effect present? \\
\hline LMX - creativity & 35 & 11098 & .33 & -.00 & .00 & -.00 & -.00 & -3.34 & .00 & .02 & $\begin{array}{l}\text { Yes, the higher the percentage } \\
\text { of male followers, the smaller } \\
\text { the correlation }\end{array}$ \\
\hline LMX - innovation & 17 & 5537 & .27 & -.00 & .00 & -.01 & -.00 & -2.18 & .03 & .01 & $\begin{array}{l}\text { Yes, the higher the percentage } \\
\text { of male followers, the smaller } \\
\text { the correlation }\end{array}$ \\
\hline Authentic - creativity & 13 & 4266 & .43 & -.01 & .00 & -.01 & -.00 & -2.46 & .01 & .04 & $\begin{array}{l}\text { Yes, the higher the percentage } \\
\text { of male followers, the smaller } \\
\text { the correlation }\end{array}$ \\
\hline Benevolent - creativity & 6 & 1780 & .25 & -.00 & .00 & -.01 & .00 & -.90 & .37 & .01 & No \\
\hline Empowering - creativity & 21 & 5458 & .34 & -.00 & .00 & -.01 & .00 & -1.29 & .20 & .03 & No \\
\hline Empowering - Innovation & 6 & 3872 & .27 & -.00 & .01 & -.01 & .01 & -.52 & .60 & .02 & No \\
\hline Servant - creativity & 11 & 4490 & .26 & -.01 & .00 & -.01 & -.00 & -2.17 & .03 & .04 & $\begin{array}{l}\text { Yes, the higher the percentage } \\
\text { of male followers, the smaller } \\
\text { the correlation }\end{array}$ \\
\hline Servant - innovation & 6 & 1443 & .27 & .00 & .01 & -.01 & .02 & .34 & .74 & .05 & No \\
\hline Authoritarian - creativity & 10 & 3980 & -.12 & -.00 & .00 & -.01 & .01 & -.20 & .84 & .03 & No \\
\hline Authoritarian - innovation & 5 & 1464 & -.12 & 0.00 & 0.02 & -0.04 & 0.04 & 0.12 & 0.90 & 0.02 & No \\
\hline Ethical - creativity & 12 & 3036 & .37 & .00 & .00 & -.01 & .01 & .20 & .84 & .04 & No \\
\hline Ethical - innovation & 7 & 2349 & .26 & -.00 & .01 & -.01 & .01 & -.33 & .74 & .02 & No \\
\hline Supportive - creativity & 13 & 4032 & .13 & -.00 & .00 & -.01 & .01 & -.52 & .60 & .04 & No \\
\hline Supportive - innovation & 7 & 1984 & .30 & -.00 & .00 & -.01 & .01 & -.49 & .62 & .02 & No \\
\hline Destructive - creativity & 13 & 4452 & -.29 & .01 & .00 & .00 & .01 & 3.20 & .00 & .00 & $\begin{array}{l}\text { Yes, the greater the percentage } \\
\text { of male followers, the smaller } \\
\text { (i.e., less negative) the } \\
\text { correlation }\end{array}$ \\
\hline
\end{tabular}


Note. $\mathrm{k}$ = number of correlations; $\mathrm{N}=$ number of respondents; $\mathrm{r}=$ sample-weighted mean correlation; $\mathrm{b}=$ Beta coefficient; $\mathrm{SD}=$ standard deviation of the beta coefficient; $\mathrm{z}$-value $=$ test of the null hypothesis that there is no difference in effect size between groups; $p$-value $=$ tests for the significance of the $\mathrm{z}$-value; $\mathrm{T} 2$ =Tau squared, the between-studies variance 
Table 4 - Relative weights analysis comparing different leadership style with the full-range model

\begin{tabular}{|c|c|c|c|c|c|c|}
\hline & \multicolumn{3}{|c|}{ Individual Creativity: Other Rated } & \multicolumn{3}{|c|}{ Individual Innovation: Other Rated } \\
\hline Leadership Style & Relative Effect & Transformational & Contingent Reward & Relative Effect & Transformational & Contingent Reward \\
\hline Empowering & 74.88 & 17.76 & 7.37 & 28.84 & 19.35 & 51.81 \\
\hline LMX & 50.80 & 35.35 & 13.84 & 19.47 & 23.82 & 56.71 \\
\hline Servant & 46.61 & 33.25 & 20.13 & 17.17 & 26.22 & 56.60 \\
\hline Ethical & 62.23 & 23.85 & 13.92 & 28.81 & 21.65 & 49.54 \\
\hline Authentic & 77.14 & 15.98 & 6.89 & $\mathrm{n} / \mathrm{a}$ & $\mathrm{n} / \mathrm{a}$ & $\mathrm{n} / \mathrm{a}$ \\
\hline Authoritarian & 12.69 & 57.14 & 30.17 & 13.74 & 23.84 & 62.42 \\
\hline Destructive & 25.90 & 53.56 & 20.54 & $\mathrm{n} / \mathrm{a}$ & $\mathrm{n} / \mathrm{a}$ & $\mathrm{n} / \mathrm{a}$ \\
\hline Supportive & 14.88 & 62.90 & 22.22 & 57.93 & 14.47 & 27.61 \\
\hline Benevolent & 26.82 & 63.18 & $\mathrm{n} / \mathrm{a}$ & $\mathrm{n} / \mathrm{a}$ & $\mathrm{n} / \mathrm{a}$ & $\mathrm{n} / \mathrm{a}$ \\
\hline Humility & 53.26 & 46.74 & $\mathrm{n} / \mathrm{a}$ & $\mathrm{n} / \mathrm{a}$ & $\mathrm{n} / \mathrm{a}$ & $\mathrm{n} / \mathrm{a}$ \\
\hline Entrepreneurial & $\mathrm{n} / \mathrm{a}$ & $\mathrm{n} / \mathrm{a}$ & $\mathrm{n} / \mathrm{a}$ & 42.61 & 57.39 & $\mathrm{n} / \mathrm{a}$ \\
\hline
\end{tabular}


Table 5 - Relative weights analysis comparing different leadership style within leadership categories

\begin{tabular}{|c|c|c|}
\hline Leadership Style & Individual Creativity: Other Rated & Individual Innovation: Other Rated \\
\hline \multicolumn{3}{|c|}{ Relationship Orientated Leadership Styles } \\
\hline LMX & 58.96 & 20.43 \\
\hline Supportive & 19.08 & 79.57 \\
\hline Benevolence & 21.96 & $\mathrm{n} / \mathrm{a}$ \\
\hline \multicolumn{3}{|c|}{ Morally Based Leadership Styles } \\
\hline Servant & 15.14 & 26.32 \\
\hline Ethical & 21.27 & 73.68 \\
\hline Authentic & 53.58 & $\mathrm{n} / \mathrm{a}$ \\
\hline Humility & 10.01 & $\mathrm{n} / \mathrm{a}$ \\
\hline \multicolumn{3}{|c|}{ Motivational Leadership } \\
\hline Empowering & $\mathrm{n} / \mathrm{a}$ & 59.86 \\
\hline Entrepreneurial & $\mathrm{n} / \mathrm{a}$ & 40.14 \\
\hline \multicolumn{3}{|c|}{ Negative Leadership } \\
\hline Authoritarian & 17.70 & $\mathrm{n} / \mathrm{a}$ \\
\hline Destructive & 82.30 & $\mathrm{n} / \mathrm{a}$ \\
\hline \multicolumn{3}{|c|}{ Transformational Leadership Dimensions } \\
\hline Idealized Influence \& Charisma & 24.06 & $\mathrm{n} / \mathrm{a}$ \\
\hline Inspirational Motivation & 20.09 & $\mathrm{n} / \mathrm{a}$ \\
\hline Intellectual Stimulation & 27.14 & $\mathrm{n} / \mathrm{a}$ \\
\hline Individualized Consideration & 28.70 & $\mathrm{n} / \mathrm{a}$ \\
\hline
\end{tabular}


Appendix A

Meta-analytic results for leadership intercorrelations needed for relative weights analysis

\begin{tabular}{|c|c|c|c|c|c|c|c|c|c|c|}
\hline \multirow[b]{2}{*}{ Variable } & \multicolumn{8}{|c|}{$95 \% \mathrm{CI}$} & \multicolumn{2}{|c|}{$80 \% \mathrm{CV}$} \\
\hline & $\mathrm{k}$ & $\mathrm{N}$ & $\mathrm{r}$ & Lower & Upper & $\rho$ & $\mathrm{SD}_{\rho}$ & $\% \mathrm{VE}$ & Lower & Upper \\
\hline Transformational - Contingent Reward ${ }^{1}$ & 87 & 22369 & 0.68 & 0.78 & 0.83 & 0.80 & & & 0.65 & 0.95 \\
\hline Transformational - Empowering ${ }^{2}$ & 5 & 1721 & 0.60 & 0.56 & 0.64 & 0.67 & 0.03 & 650.72 & 0.63 & 0.70 \\
\hline Transformational - Ethical ${ }^{3}$ & 20 & 3717 & 0.63 & 0.62 & 0.79 & 0.70 & 0.17 & & 0.48 & 0.93 \\
\hline Transformational - Authentic ${ }^{4}$ & 23 & 5414 & 0.70 & 0.60 & 0.83 & 0.72 & 0.27 & & 0.37 & 1.00 \\
\hline Transformational - LMX ${ }^{5}$ & 20 & 5451 & 0.66 & 0.49 & 0.97 & 0.73 & 0.19 & & 0.49 & 0.97 \\
\hline Transformational - Destructive & 8 & 1242 & -0.49 & -0.56 & -0.41 & -0.56 & 0.07 & 460.60 & -0.65 & -0.46 \\
\hline Transformational - Servant ${ }^{6}$ & 14 & 3867 & 0.45 & 0.40 & 0.51 & 0.52 & 0.11 & & & \\
\hline Transformational - Authoritarian ${ }^{7}$ & 12 & 3829 & -0.29 & -0.45 & -0.13 & -0.29 & 0.28 & & -0.65 & 0.06 \\
\hline Transformational - Entrepreneurial & 2 & 583 & 0.85 & 0.79 & 0.91 & 0.93 & 0.04 & 17.64 & 0.88 & 0.98 \\
\hline Transformational - Humble & 3 & 497 & 0.73 & 0.61 & 0.84 & 0.80 & 0.16 & 6.52 & 0.60 & 1.00 \\
\hline Transformational - Benevolent $^{7}$ & 10 & 3671 & 0.66 & 0.64 & 0.78 & 0.71 & 0.10 & & 0.58 & 0.84 \\
\hline Transformational - Supportive & 4 & 1184 & 0.67 & 0.46 & 0.87 & 0.75 & 0.18 & 3.78 & 0.52 & 0.98 \\
\hline Contingent Reward - LMX ${ }^{5}$ & 6 & 1900 & 0.65 & 0.58 & 0.88 & 0.73 & 0.18 & & 0.51 & 0.96 \\
\hline Contingent Reward - Empowering & 5 & 1864 & 0.46 & 0.23 & 0.68 & 0.54 & 0.30 & 2.51 & 0.15 & 0.93 \\
\hline Contingent Reward - Ethical ${ }^{8}$ & 7 & 1156 & 0.63 & 0.64 & 0.86 & 0.75 & 0.15 & & 0.50 & 1.00 \\
\hline Contingent Reward- Authentic & 3 & 711 & 0.50 & 0.41 & 0.60 & 0.59 & 0.05 & 55.35 & 0.52 & 0.65 \\
\hline Contingent Reward- Destructive & 4 & 907 & -0.31 & -0.45 & -0.17 & -0.34 & 0.16 & 15.32 & -0.55 & -0.14 \\
\hline Contingent Reward- Servant & 3 & 475 & 0.70 & 0.60 & 0.79 & 0.80 & 0.14 & 10.65 & 0.62 & 0.97 \\
\hline Contingent Reward- Authoritarian & 3 & 905 & 0.23 & 0.08 & 0.37 & 0.27 & 0.18 & 11.94 & 0.04 & 0.50 \\
\hline Contingent Reward- Supportive & 3 & 788 & 0.61 & 0.35 & 0.88 & 0.71 & 0.26 & 2.76 & 0.38 & 1.00 \\
\hline Ethical - Authentic ${ }^{6}$ & 3 & 462 & 0.77 & 0.56 & 0.98 & 0.85 & 0.15 & & & \\
\hline Ethical - Servant ${ }^{6}$ & 4 & 3106 & 0.74 & 0.62 & 0.86 & 0.82 & 0.11 & & & \\
\hline
\end{tabular}




\begin{tabular}{|c|c|c|c|c|c|c|c|c|c|c|}
\hline \multirow[b]{2}{*}{ Variable } & \multicolumn{8}{|c|}{$95 \% \mathrm{CI}$} & \multicolumn{2}{|c|}{$80 \% \mathrm{CV}$} \\
\hline & $\mathrm{k}$ & $\mathrm{N}$ & $\mathrm{r}$ & Lower & Upper & $\rho$ & $\mathrm{SD}_{\rho}$ & $\% \mathrm{VE}$ & Lower & Upper \\
\hline Authentic-Servant ${ }^{6}$ & 5 & 2686 & 0.78 & 0.67 & 0.89 & 0.84 & 0.11 & & & \\
\hline Authentic- Humble & 3 & 796 & 0.59 & 0.47 & 0.71 & 0.68 & 0.15 & 9.02 & 0.49 & 0.87 \\
\hline Servant - Humble* & 1 & 283 & & & & 0.81 & & & & \\
\hline Ethical - Humble & 2 & 545 & 0.75 & 0.57 & 0.93 & 0.79 & 0.12 & 4.78 & 0.63 & 0.95 \\
\hline LMX - Benevolence $^{7}$ & 7 & 2619 & 0.64 & 0.67 & 0.79 & 0.73 & 0.07 & & 0.63 & 0.82 \\
\hline LMX - Supportive & 7 & 2137 & 0.67 & 0.57 & 0.77 & 0.79 & 0.14 & 6.43 & 0.61 & 0.97 \\
\hline Supportive - Benevolence & 5 & 1674 & 0.51 & 0.39 & 0.64 & 0.57 & 0.15 & 8.49 & 0.38 & 0.75 \\
\hline Empowering - Entrepreneurial* & 1 & 346 & & & & 0.71 & & & & \\
\hline Destructive - Authoritarian & 4 & 882 & 0.63 & 0.49 & 0.78 & 0.74 & 0.16 & 7.84 & 0.54 & 0.95 \\
\hline
\end{tabular}

Note. Results are corrected for criterion and predictor unreliability. $k=$ number of correlations; $N=$ number of respondents; $r=$ sample weighted

mean correlation; $\rho=$ corrected population correlation; $S D_{\rho}=$ standard deviation of the corrected population correlation; $\% \mathrm{VE}=$ percentage of

variance attributed to sampling error in corrected population correlation; 95\% CI $=95 \%$ confidence interval around the sample weighted mean correlation; $80 \% \mathrm{CV}=80 \%$ credibility interval around the corrected population correlation

1 = Judge \& Piccolo, 2004; 2 = Lee, Willis, \& Tian, 2018; 3 = Hoch, Bommer, Dulebohn, \& Wu, 2018; 4 = Banks, McCauley, Gardner, \& Guler, 2016; 5 = Dulebohn, Bommer, Liden, Brouer, \& Ferris, 2012; 6 = Lee, Lyubovnikova, Tian, \& Knight, 2019; 7 = Hiller, Sin, Ponnapalli,

\& Ozgen, 2019; 8 = Ng \& Feldman, 2015

*- Correlation based on a single study only 


\section{APPENDIX B}

Meta-analytic results for dichotomous moderators

\begin{tabular}{|c|c|c|c|c|c|c|c|c|c|c|}
\hline \multirow[b]{2}{*}{ Variable } & \multirow[b]{2}{*}{$k$} & \multicolumn{7}{|c|}{$95 \% \mathrm{CI}$} & \multicolumn{2}{|c|}{$80 \% \mathrm{CV}$} \\
\hline & & $N$ & $r$ & Lower & Upper & $\rho$ & $S D_{\rho}$ & $\% \mathrm{VE}$ & Lower & Upper \\
\hline \multicolumn{11}{|l|}{ Transformational Leadership } \\
\hline Creativity: Published & 46 & 15800 & 0.29 & 0.24 & 0.34 & 0.32 & 0.21 & 6.81 & 0.06 & 0.59 \\
\hline Creativity: Unpublished & 9 & 2322 & 0.22 & 0.13 & 0.30 & 0.23 & 0.13 & 19.65 & 0.07 & 0.40 \\
\hline Innovation: Published & 27 & 9868 & 0.27 & 0.20 & 0.33 & 0.30 & 0.19 & 8.11 & 0.06 & 0.54 \\
\hline Innovation: Unpublished & 6 & 995 & 0.22 & 0.07 & 0.36 & 0.25 & 0.17 & 18.94 & 0.03 & 0.47 \\
\hline Creativity: Cross-sectional & 43 & 14850 & 0.28 & 0.23 & 0.34 & 0.32 & 0.19 & 7.72 & 0.07 & 0.56 \\
\hline Creativity: Time-separated & 9 & 2602 & 0.28 & 0.15 & 0.40 & 0.31 & 0.21 & 7.61 & 0.04 & 0.57 \\
\hline Innovation: Cross-sectional & 25 & 8082 & 0.29 & 0.23 & 0.35 & 0.33 & 0.17 & 10.06 & 0.10 & 0.55 \\
\hline Innovation: Time-separated & 8 & 2781 & 0.18 & 0.07 & 0.30 & 0.20 & 0.19 & 8.89 & -0.04 & 0.44 \\
\hline Creativity: High Knowledge Intensity & 32 & 9567 & 0.16 & 0.20 & 0.32 & 0.29 & 0.19 & 9.36 & 0.05 & 0.52 \\
\hline Creativity: Low Knowledge Intensity & 6 & 2994 & 0.24 & 0.19 & 0.30 & 0.29 & 0.07 & 33.43 & 0.20 & 0.37 \\
\hline Innovation: High Knowledge Intensity & 23 & 8834 & 0.26 & 0.20 & 0.32 & 0.29 & 0.17 & 9.05 & 0.07 & 0.51 \\
\hline Innovation: Low Knowledge Intensity & 7 & 1897 & 0.23 & 0.06 & 0.39 & 0.25 & 0.24 & 6.63 & -0.06 & 0.56 \\
\hline \multicolumn{11}{|l|}{ Transactional Leadership } \\
\hline Creativity: High Knowledge Intensity & 8 & 2723 & 0.06 & -0.07 & 0.20 & 0.08 & 0.22 & 7.56 & -0.20 & 0.35 \\
\hline Creativity: Low Knowledge Intensity & 2 & 1056 & -0.07 & -0.36 & 0.21 & -0.10 & 0.23 & 4.61 & -0.39 & 0.20 \\
\hline \multicolumn{11}{|l|}{ LMX } \\
\hline Creativity: Published & 34 & 10899 & 0.30 & 0.26 & 0.35 & 0.34 & 0.13 & 15.74 & 0.17 & 0.51 \\
\hline Creativity: Unpublished & 5 & 772 & 0.28 & 0.11 & 0.45 & 0.30 & 0.19 & 14.59 & 0.05 & 0.55 \\
\hline Creativity: Cross-sectional & 28 & 7651 & 0.33 & 0.28 & 0.38 & 0.37 & 0.13 & 17.17 & 0.20 & 0.54 \\
\hline Creativity: Time-separated & 11 & 4020 & 0.25 & 0.17 & 0.33 & 0.28 & 0.13 & 15.70 & 0.12 & 0.44 \\
\hline Innovation: Cross-sectional & 19 & 5752 & 0.27 & 0.22 & 0.32 & 0.31 & 0.11 & 25.20 & 0.18 & 0.45 \\
\hline
\end{tabular}




\begin{tabular}{|c|c|c|c|c|c|c|c|c|c|c|}
\hline \multirow[b]{2}{*}{ Variable } & \multirow[b]{2}{*}{$k$} & \multicolumn{7}{|c|}{$95 \% \mathrm{CI}$} & \multicolumn{2}{|c|}{$80 \% \mathrm{CV}$} \\
\hline & & $N$ & $r$ & Lower & Upper & $\rho$ & $S D_{\rho}$ & $\% \mathrm{VE}$ & Lower & Upper \\
\hline Innovation: Time-separated & 2 & 360 & 0.26 & 0.24 & 0.27 & 0.30 & 0.00 & 100.00 & 0.30 & 0.30 \\
\hline Creativity: High Knowledge Intensity & 28 & 8197 & 0.30 & 0.25 & 0.35 & 0.33 & 0.14 & 16.22 & 0.16 & 0.51 \\
\hline Creativity: Low Knowledge Intensity & 5 & 1265 & 0.26 & 0.19 & 0.34 & 0.30 & 0.06 & 54.60 & 0.22 & 0.38 \\
\hline Innovation: High Knowledge Intensity & 18 & 5183 & 0.24 & 0.20 & 0.28 & 0.28 & 0.06 & 54.05 & 0.20 & 0.35 \\
\hline Innovation: Low Knowledge Intensity & 3 & 929 & 0.44 & 0.35 & 0.53 & 0.50 & 0.06 & 39.63 & 0.42 & 0.58 \\
\hline \multicolumn{11}{|l|}{ Empowering Leadership } \\
\hline Creativity: Published & 20 & 5172 & 0.32 & 0.26 & 0.37 & 0.35 & 0.13 & 19.06 & 0.19 & 0.51 \\
\hline Creativity: Unpublished & 2 & 638 & 0.38 & -0.07 & 0.83 & 0.44 & 0.39 & 2.07 & -0.06 & 0.94 \\
\hline Creativity: Cross-sectional & 17 & 4569 & 0.33 & 0.25 & 0.42 & 0.36 & 0.18 & 9.56 & 0.13 & 0.60 \\
\hline Creativity: Time-separated & 5 & 1241 & 0.29 & 0.18 & 0.40 & 0.33 & 0.12 & 23.60 & 0.18 & 0.48 \\
\hline Creativity: High Knowledge Intensity & 16 & 4015 & 0.33 & 0.24 & 0.41 & 0.36 & 0.18 & 10.39 & 0.12 & 0.60 \\
\hline Creativity: Low Knowledge Intensity & 6 & 1629 & 0.32 & 0.20 & 0.43 & 0.35 & 0.15 & 13.38 & 0.15 & 0.54 \\
\hline \multicolumn{11}{|l|}{ Servant Leadership } \\
\hline Creativity: Cross-sectional & 8 & 3819 & 0.35 & 0.19 & 0.52 & 0.39 & 0.26 & 2.84 & 0.06 & 0.73 \\
\hline Creativity: Time-separated & 3 & 671 & 0.25 & 0.15 & 0.36 & 0.30 & 0.09 & 41.77 & 0.19 & 0.41 \\
\hline \multicolumn{11}{|l|}{ Supportive Leadership } \\
\hline Creativity: High Knowledge Intensity & 7 & 2381 & 0.15 & 0.04 & 0.26 & 0.16 & 0.17 & 11.42 & -0.05 & 0.37 \\
\hline Creativity: Low Knowledge Intensity & 3 & 670 & 0.34 & 0.19 & 0.49 & 0.41 & 0.16 & 18.23 & 0.22 & 0.61 \\
\hline Innovation: High Knowledge Intensity & 6 & 2282 & 0.28 & 0.21 & 0.35 & 0.32 & 0.09 & 25.01 & 0.20 & 0.44 \\
\hline Innovation: Low Knowledge Intensity & 2 & 488 & 0.45 & 0.35 & 0.55 & 0.53 & 0.09 & 33.62 & 0.42 & 0.64 \\
\hline \multicolumn{11}{|l|}{ Authentic Leadership } \\
\hline Creativity: Cross-sectional & 13 & 4291 & 0.48 & 0.41 & 0.55 & 0.53 & 0.13 & 11.14 & 0.36 & 0.70 \\
\hline Creativity: Time-separated & 3 & 797 & 0.14 & 0.06 & 0.21 & 0.15 & 0.05 & 67.90 & 0.09 & 0.21 \\
\hline Creativity: High Knowledge Intensity & 8 & 2297 & 0.35 & 0.20 & 0.49 & 0.40 & 0.23 & 6.19 & 0.10 & 0.69 \\
\hline Creativity: Low Knowledge Intensity & 4 & 1490 & 0.50 & 0.38 & 0.63 & 0.55 & 0.13 & 10.12 & 0.39 & 0.71 \\
\hline
\end{tabular}

\section{Destructive Leadership}




\begin{tabular}{|c|c|c|c|c|c|c|c|c|c|c|}
\hline \multirow[b]{2}{*}{ Variable } & \multirow[b]{2}{*}{$k$} & \multicolumn{7}{|c|}{$95 \% \mathrm{CI}$} & \multicolumn{2}{|c|}{$80 \% \mathrm{CV}$} \\
\hline & & $N$ & $r$ & Lower & Upper & $\rho$ & $S D_{\rho}$ & $\% \mathrm{VE}$ & Lower & Upper \\
\hline Creativity: Cross-sectional & 6 & 1992 & -0.19 & -0.29 & -0.10 & -0.21 & 0.12 & 18.52 & -0.37 & -0.05 \\
\hline Creativity: Time-separated & 7 & 2804 & -0.19 & -0.27 & -0.12 & -0.22 & 0.10 & 23.69 & -0.34 & -0.09 \\
\hline Creativity: High Knowledge Intensity & 9 & 2986 & -0.19 & -0.28 & -0.10 & -0.22 & 0.14 & 14.83 & -0.41 & -0.03 \\
\hline Creativity: Low Knowledge Intensity & 3 & 861 & -0.17 & -0.21 & -0.13 & -0.18 & 0.00 & 100.00 & -0.18 & -0.18 \\
\hline
\end{tabular}

Note. $k=$ number of correlations; $N=$ number of respondents; $r=$ sample weighted mean correlation; $\rho=$ corrected population correlation; $S D_{\rho}=$

standard deviation of the corrected population correlation; \% VE = percentage of variance attributed to sampling error in corrected population

correlation; $95 \% \mathrm{CI}=95 \%$ confidence interval around the sample weighted mean correlation; $80 \% \mathrm{CV}=80 \%$ credibility interval around the corrected population correlation 


\section{APPENDIX C}

List of papers used in meta-analysis

\section{Transformational Leadership - Creativity}

Akinlade, 2014

Arendt, 2009

Bae, Song, Park, \& Kim, 2013

Cai, Lysova, Khapova, \& Bossink, 2019

Carmeli, Sheaffer, Binyamin, Reiter-Palmon, \& Shimoni, 2013

Chang \& Teng, 2017

Chaubey, Sahoo, \& Khatri, 2019

Charbonnier-Voirin, Akremi, \& Vandenberghe, 2010

Cheung \& Wong, 2011

Dong, Bartol, Zhang, \& Li, 2017

Eisenbeiss \& Boerner, 2013

Ghafoor, Qureshi, Azeemi, \& Hijazi, 2011

Gilmore, Hu, Wei, Tetrick, \& Zaccaro, 2013

Golden, 2016

Gong, Huang, \& Farh, 2009

Gumusluoglu \& Ilsev, 2009

Henker, 2013

Henker, Sonnentag, \& Unger, 2015
Hirst, van Dick, \& van

Knippenberg, 2009

Jaffer, 2013

Jaiswal \& Dhar, 2016

Jaussi \& Dionne, 2003

Jyoti \& Dev, 2015

Kark, Van Dijk, \& Vashdi, 2018 (2 studies)

Kim, 2000

Khalili, 2016

Kim \& Lee, 2011

Kollman, Stockmann, \& Krell (2011)

Koseoglu, Liu, \& Shalley, 2017

Li, Yu, Yang, Qi, \& Fu, 2014 (2 studies)

Li, Zhao, \& Begley, 2015

Luu, 2017

Ma \& Jiang, 2018

Miao \& Wang, 2016

Mittal \& Dhar, 2015

Monowar Mahmood, \& Luo, 2019
Moss \& Ritossa, 2007

Nguyen, 2017

Qu, Janssen, \& Shi, 2015

Rickards, Chen, \& Moger, 2001

Shin \& Zhou, 2003

Si \& Wei, 2012

Sosik, Kahai, \& Avolio, 1999

Suifan, Abdallah, \& Al Janini, 2018

Sun, Zhang, Chen, 2012

Taylor, 2015

Tse \& Chiu, 2014

Tse, To, \& Chiu, 2017

Tung, 2016

Wang \& Rode, 2010

Wang \& Zhu, 2011

Wang, Tsai \& Tsai, 2014

Zacher \& Johnson, 2015

Zhou \& Pan, 2015 


\begin{tabular}{|c|c|c|}
\hline \multicolumn{3}{|c|}{ Transformational Leadership - Innovation } \\
\hline $\begin{array}{l}\text { Afsar, Badir, \& Bin Saeed, } \\
2014\end{array}$ & Kang, Solomon \& Choi, 2015 & $\begin{array}{l}\text { Rank, Nelson Allen,\& Xu, } \\
2009\end{array}$ \\
\hline Basu \& Green, 1995 & Khalili, 2016 & Sethibe \& Steyn, 2017 \\
\hline $\begin{array}{l}\text { Boerner, Eisenbeiss, \& } \\
\text { Griesser, } 2007\end{array}$ & Kang, 2013 & Slåtten, 2014 \\
\hline Chang, Bai, \& Li, 2015 & Kao, Pai, Lin, \& Zhong, 2015 & $\begin{array}{l}\text { Saeed, Afsar, Shahjehan, \& } \\
\text { Shah, } 2019 \text { ( } 2 \text { studies) }\end{array}$ \\
\hline $\begin{array}{l}\text { Choi, Kim, Ullah, \& Kang, } \\
2016\end{array}$ & Lee, 2008 & $\begin{array}{l}\text { Turunc, Celik, Tabak, \& } \\
\text { Kabak } 2010\end{array}$ \\
\hline $\begin{array}{l}\text { Chen, Farh, Campbell- } \\
\text { Bush, Wu, \& Wu, } 2013\end{array}$ & Li, Mitchell, \& Boyle, 2016 & Vazquez, 2016 \\
\hline Craig, 2015 & $\begin{array}{l}\text { Miao, Newman, \& Lamb, } \\
2012\end{array}$ & $\begin{array}{l}\text { Weng, Huang, Chen, \& } \\
\text { Chang, } 2015\end{array}$ \\
\hline Gross, 2016 & $\begin{array}{l}\text { Newman, Tse, Schwarz, \& } \\
\text { Nielsen, } 2018\end{array}$ & $\begin{array}{l}\text { Zhang, Lepine, Buckman, \& } \\
\text { Wei, } 2014\end{array}$ \\
\hline $\begin{array}{l}\text { Günzel-Jensen, } \\
\text { Hansen,Jakobsen \& Wulff, } \\
2018\end{array}$ & $\begin{array}{l}\text { Pieterse, van Knippenberg, } \\
\text { Schippers, \& Stam, } 2010\end{array}$ & $\begin{array}{l}\text { Zhang, Zheng, \& Darko, } \\
2018\end{array}$ \\
\hline $\begin{array}{l}\text { Hussain, Talib, \& Shah, } \\
2014\end{array}$ & Pundt, 2015 & $\begin{array}{l}\text { Zhu, Wang, Zheng, Liu, \& } \\
\text { Miao, } 2013\end{array}$ \\
\hline Iskandarani, 2017 & Rada, 2018 & Zhu \& Mu, 2016 \\
\hline \multicolumn{3}{|c|}{ Transactional Leadership - Creativity } \\
\hline $\begin{array}{l}\text { Kark, Van Dijk, \& Vashdi, } \\
2018\end{array}$ & Moss \& Ritossa, 2007 & $\begin{array}{l}\text { Sosik, Kahai, \& Avolio, } \\
1999\end{array}$ \\
\hline Kim, 2000 & $\begin{array}{l}\text { Rickards, Chen, \& Moger, } \\
2001\end{array}$ & Tung, 2016 \\
\hline Kim \& Lee, 2011 & Sanda \& Arthur, 2017 & Wei, Yuan, \& Di, 2010 \\
\hline Ma \& Jiang, 2018 & Si \& Wei, 2012 & Zacher \& Johnson, 2015 \\
\hline \multicolumn{3}{|c|}{ Transactional Leadership - Innovation } \\
\hline Chang, Bai \& Li, 2015 & $\begin{array}{l}\text { Günzel-Jensen, } \\
\text { Hansen,Jakobsen \& Wulff, } \\
2018\end{array}$ & $\begin{array}{l}\text { Rank, Nelson, Allen, \& Xu, } \\
2009\end{array}$ \\
\hline Elenkov \& Manev, 2005 & $\begin{array}{l}\text { Kang, Soloman, \& Choi, } \\
2015\end{array}$ & Sethibe \& Steyn, 2017 \\
\hline $\begin{array}{l}\text { Elenkov, Judge, \& Wright, } \\
2005\end{array}$ & Lee, 2008 & $\begin{array}{l}\text { Turunc, Celik, Tabak, \& } \\
\text { Kabak, } 2010\end{array}$ \\
\hline Gross, 2016 & $\begin{array}{l}\text { Pieterse, van Knippenberg, } \\
\text { Schippers \& Stam, } 2010\end{array}$ & \\
\hline
\end{tabular}




\section{Authentic Leadership - Creativity}

Černe, Jaklič, \& Škerlavaj, $\quad$ Mubarak \& Noor, 2018 2013

Semedo, Coelho, \& Ribeiro, Chaudh 2016

Chaudhary \& Panda, 2018

Rego, Sousa, Marques, \& Cunha, 2012

Semedo, Coelho, \& Ribeiro, 2017

Li, Lu, Yang, Qi, \& Fu,

Rego, Sousa, Maruques, \& 2014 (2 studies) Cunha, 2014

Semedo, Coelho, \& Ribeiro, 2018

Malik, Dhar \& Handa, 2016

Ribeiro, Duarte \& Filipe, 2018

Meng, Cheng \& Guo, 2016 Sanda \& Arthur, 2017

Sercan, 2016

Xu, Zhao, Li, \& Lin, 2017

\section{Empowering Leadership - Creativity}

Al-Madadha, 2016

Amundsen \& Martinsen, 2014a

Amundsen \& Martinsen, 2014b

Amundsen \& Martinsen, 2015

Audenaert \& Decramer, Hwang, 2013 2016

Byun, Dai, Lee, \& Kang, Kim, 2019 2016

Chow, 2018

Empowering Leadership - Innovation

Chen, Sharma, Edinger, Shapiro, \& Farh, 2011 (2 studies)

Günzel-Jensen, Hansen,Jakobsen \& Wulff, 2018

De Jong \& Den Hartog, 2010

Newman, Tse, Schwarz, \& Nielsen, 2018

Slåtten, Svensson, \& Sværi, 2011

Odoardi, Montani, Boudrias, \& Battistelli, 2014

Liu, Gong, Zhou, \& Huang, 2017

Slåtten, Svensson, \& Sværi, 2011

Tung \& Yu, 2015

Zhang \& Bartol, 2010

Zhang, Ke, Wang, \& Liu, 2018

Zhang \& Zhou, 2014 (2 studies)

Sagnak, 2012

Gkorezis, 2016

\section{Servant Leadership - Creativity}

Do, Budhwar, \& Patel, 2018
Liden, Wayne, Meuser, $\mathrm{Hu}$, Wu, \& Liao, 2015
Williams Jr, Brandon, Hayek, Haden, \& Atinc, 2017 
Jaiswal \& Dhar, 2017

Jaramillo, Grisaffe,

Chonko, \& Roberts, 2009

Karatepe, Ozturk \& Kim, 2019
Malingumu, Stouten, Euwema, \& Babyegeya, 2016

Neubert, Hunter, \&

Tolentino, 2016

Neubert, Kacmar, Carlson,

Chonko, \& Roberts, 2008
Yang, Liu, \& Gu, 2017

Yoshida, Sendjaya, Hirst, \& Cooper, 2014

Weaver, 2017

\section{Servant Leadership - Innovation}

Krog \& Govender, $2015 \quad$ Searle, 2011

Sun, 2016

Newman, Neesham,

Manville, \& Tse, 2017

Panaccio, Henderson,

Topcu, Gursoy, \& Gurson,

Liden, Wayne, \& Cao, 20152015

\section{Destructive Leadership - Creativity}

Choi, Anderson, \& Veilette, Jiang, Gu, \& Tang, 2017 2009

Naseer,Raja, Syed, Donia,

Gu, Song, \& Wu, 2016

Lee, Yun, \& Srivastava, 2013

\& Darr, 2016

Guo, Decoster, Babalola,

Schutter, Garba, \& Riisla,

Liu, Liao, \& Loi, 2012

Rasool, Naseer, Syed, \& Ahmad, 2018

2018 (2 studies)

Zhang, Kwan, Zhang, \& $\mathrm{Wu}, 2014$

Han, Harms, \& Bai, 2017

Liu, Zhang, Liao, Hao, \&

Mao, 2016

Jiang \& Gu, 2016

Meng, Tan, \& Li, 2017

\section{Authoritarian Leadership - Creativity}

Dedahanov, Lee, Rhee, \&

Yoon, 2016

Gu, He, \& Liu, 2017
Hwang, 2013

Guo, Decoster, Babalola, Schutter, Garba, \& Riisla, 2018 (2 studies)
Wang, Chiang, Tsai, Lin, \& Cheng, 2013

Wang, Tang, Naumann, \& Yang, 2019

Pan, Wu, Zhou, \& Lou, $2015 \quad$ Wu, 2018

Gu, Wang, Liu, Song, \& He, 2018

\section{Authoritarian Leadership - Innovation}

Dedahanov, Bozorov, \& Mansur, 2016

Sung, 2019

Karakitapoğlu-Aygün,

Gumusluoglu, \& Scandura, 2019
Wang, Chang, \& Wang, 2018

$\mathrm{Wu}, 2018$

Wu, 2018

Tian \& Sanchez, 2017 


\begin{tabular}{|c|c|c|}
\hline \multicolumn{3}{|c|}{ Entrapreneurial Leadership - Creativity } \\
\hline Bagheri, 2017 & Bagheri \& Akbari, 2018 & $\begin{array}{l}\text { Cai, Lysova, Khapova, \& } \\
\text { Bossink, } 2019\end{array}$ \\
\hline \multicolumn{3}{|l|}{ LMX - Creativity } \\
\hline Akinlade, 2014 & $\begin{array}{l}\text { Lee, Scandura, Kim, Joshi, \& } \\
\text { Lee, } 2012\end{array}$ & Ramos, 2003 \\
\hline $\begin{array}{l}\text { Aleksić, Mihelič, Černe, \& } \\
\text { Škerlavaj, } 2017\end{array}$ & Khalili, 2018 & $\begin{array}{l}\text { Pan, Wu, Zhou, \& Lou, } \\
2015\end{array}$ \\
\hline Atwater \& Carmeli, 2009 & $\begin{array}{l}\text { Kong, Xu, Zhou, \& Yuan, } \\
2019\end{array}$ & Sercan, 2016 \\
\hline Chughtai, 2016 & Li, Chen, \& Cao, 2017 & Son, Cho, \& Kang, 2017 \\
\hline $\begin{array}{l}\text { Gong, Kim, Lee, \& Zhu, } \\
2013\end{array}$ & Liao, Chen, \& Hu, 2018 & Tierney, 1992 \\
\hline Gu, Tang, \& Jiang, 2015 & Liao, Liu, \& Loi, 2010 & $\begin{array}{l}\text { Tierney, Farmer, \& Graen, } \\
1999\end{array}$ \\
\hline $\begin{array}{l}\text { Gu, Wang, Liu, Song, \& } \\
\text { He, } 2018\end{array}$ & $\begin{array}{l}\text { Lin, Ma, Zhang, Li, \& Jiang, } \\
2018\end{array}$ & Xu, Zhao, Li, \& Lin, 2017 \\
\hline Hassanzadeh, 2014 & $\begin{array}{l}\text { Martinaityte \& Sacramento, } \\
2013\end{array}$ & $\begin{array}{l}\text { Volmer, Spurk, \& Niessen, } \\
2012\end{array}$ \\
\hline $\begin{array}{l}\text { Huang, Krasikova, \& Liu, } \\
2016\end{array}$ & Meng, Tan, \& Li, 2017 & Wang, 2016 \\
\hline Jaffer, 2013 & $\begin{array}{l}\text { Munoz-Doyague, \& Nieto, } \\
2012\end{array}$ & Zaitouni \& Ouakouak, 2018 \\
\hline Jiang \& Yang, 2015 & $\begin{array}{l}\text { Naseer, Raja, Syed, Donia, \& } \\
\text { Darr, } 2016\end{array}$ & Zhang, Fan, \& Zhang, 2015 \\
\hline Joo \& Bennett, 2018 & Pan, Sun, \& Chow, 2012 & $\begin{array}{l}\text { Zhao, Kessel, \& Kratzer, } \\
2014\end{array}$ \\
\hline $\begin{array}{l}\text { Joo, Yang, \& McLean, } \\
2014\end{array}$ & Qu, Janssen, \& Shi, 2017 & \\
\hline \multicolumn{3}{|l|}{ LMX - Innovation } \\
\hline Atitumpong \& Badir, 2017 & Khalili, 2018 & Scott, 1993 \\
\hline Basu \& Green, 1995 & Lee, 2008 & $\begin{array}{l}\text { Scott \& Bruce, } 1998 \text { (2 } \\
\text { studies) }\end{array}$ \\
\hline $\begin{array}{l}\text { Clegg, Unsworth, } \\
\text { Epitropaki, \& Parker, } 2002\end{array}$ & Liao \& Chun, 2016 & Song, Liu, Gu, \& He, 2018 \\
\hline
\end{tabular}




\begin{tabular}{|c|c|c|}
\hline Denti, 2011 & Park \& Jo, 2018 & $\begin{array}{l}\text { Turunc, Celik, Tabak, \& } \\
\text { Kabak, } 2010\end{array}$ \\
\hline Denti \& Hemlin, 2015 & Pundt, 2015 & $\begin{array}{l}\text { Wang, Fang, Qureshi, \& } \\
\text { Janssen, } 2015\end{array}$ \\
\hline $\begin{array}{l}\text { Janssen \& van Yperen, } \\
2004\end{array}$ & $\begin{array}{l}\text { Sanders, Moorkamp, Torka, } \\
\text { Groeneveld, \& Groeneveld, } \\
2010\end{array}$ & Wu, Liu, Kim, \& Gao, 2018 \\
\hline Kim \& Koo, 2017 & $\begin{array}{l}\text { Schermuly, Meyer, \& } \\
\text { Dämmer, } 2013\end{array}$ & Yuan, 2005 \\
\hline \multicolumn{3}{|c|}{ Benevolent Leadership - Creativity } \\
\hline $\begin{array}{l}\text { Dedahanov, Lee, Rhee, \& } \\
\text { Yoon, } 2016\end{array}$ & Wang \& Cheng, 2010 & $\begin{array}{l}\text { Wang, Tang, Naumann, \& } \\
\text { Yang, } 2019\end{array}$ \\
\hline $\begin{array}{l}\text { Lin, Ma, Zhang, Li, \& } \\
\text { Jiang, } 2018\end{array}$ & $\begin{array}{l}\text { Wang, Chiang, Tsai, Lin, \& } \\
\text { Cheng, } 2013\end{array}$ & $\mathrm{Wu}, 2018$ \\
\hline \multicolumn{3}{|c|}{ Benevolent Leadership - Innovation } \\
\hline $\begin{array}{l}\text { Dedahanov, Bozorov, \& } \\
\text { Sung, } 2019\end{array}$ & Tian \& Sanchez, 2017 & $\mathrm{Wu}, 2018$ \\
\hline $\begin{array}{l}\text { Karakitapoğlu-Aygün, } \\
\text { Gumusluoglu, \& Scandura, } \\
2019\end{array}$ & Wang, Chang, \& Wang, 2018 & \\
\hline \multicolumn{3}{|c|}{ Humble Leadership - Innovation } \\
\hline Tuan, 2019 & Wang, Zhang, \& Jia, 2017 & \\
\hline Wang, Liu, \& Zhu, 2018 & Yuan, Zhang, \& Tu, 2018 & \\
\hline \multicolumn{3}{|c|}{ Supportive Leadership - Creativity } \\
\hline Cheung \& Wong, 2011 & Hwang, 2013 & $\begin{array}{l}\text { Škerlavaj Černe, \& Dysvik, } \\
2014\end{array}$ \\
\hline Choi, 2004 & Jafri, 2018 & $\begin{array}{l}\text { Unsworth, Wall, \& Carter, } \\
2005\end{array}$ \\
\hline Darvishmotevali, 2019 & Lim \& Choi, 2009 & Wang, Xue, \& Su, 2010 \\
\hline George \& Zhou, 2007 & $\begin{array}{l}\text { Ohly, Sonnentag, \& Pluntke, } \\
2006\end{array}$ & Zaitouni \& Ouakouak, 2018 \\
\hline Gu, He, \& Liu, 2017 & Oldham \& Cumming, 1996 & \\
\hline \multicolumn{3}{|c|}{ Supportive Leadership - Innovation } \\
\hline $\begin{array}{l}\text { Chen, Li, \& Leung, } 2016 \text { ( } 2 \\
\text { studies) }\end{array}$ & $\begin{array}{l}\text { Ohly, Sonnentag, \& Pluntke, } \\
2006\end{array}$ & Yasir \& Majid, 2018 \\
\hline Darvishmotevali, 2019 & $\begin{array}{l}\text { Škerlavaj Černe, \& Dysvik, } \\
2014\end{array}$ & \\
\hline
\end{tabular}




\begin{tabular}{|c|c|c|}
\hline \multirow{2}{*}{\multicolumn{3}{|c|}{$\begin{array}{l}\text { Janssen, } 2005 \text { Sönn } \\
\text { Ethical Leadership - Creativity }\end{array}$}} \\
\hline & & \\
\hline Chen \& Hou, 2016 & $\begin{array}{l}\text { Feng, Zhang, Liu, Zhang, \& } \\
\text { Han, } 2016\end{array}$ & Mehmood, 2016 \\
\hline \multirow{2}{*}{$\begin{array}{l}\text { Chughtai, } 2016 \\
\text { Dedahanov, Lee, Rhee, \& } \\
\text { Yoon, } 2016\end{array}$} & Gu, Tang, \& Jiang, 2015 & Sercan, 2016 \\
\hline & $\begin{array}{l}\text { Javed, Khan, Bashir, \& } \\
\text { Arjoon, } 2017\end{array}$ & $\begin{array}{l}\text { Wang, Tang, Naumann, \& } \\
\text { Yang, } 2019\end{array}$ \\
\hline $\begin{array}{l}\text { Dedahanov, Lee, Rhee, \& } \\
\text { Yoon, } 2016\end{array}$ & $\begin{array}{l}\text { Javed, Rawwas, } \\
\text { Khandai,Shahid, \& Tayyeb, } \\
2018\end{array}$ & Wu, 2018 \\
\hline Duan, Liu, \& Che, 2018 & $\begin{array}{l}\text { Ma, Cheng, Ribbens, \& } \\
\text { Zhou, } 2013\end{array}$ & \\
\hline \multicolumn{3}{|c|}{ Ethical Leadership - Innovation } \\
\hline $\begin{array}{l}\text { Dedahanov, Bozorov, \& } \\
\text { Sung, } 2019\end{array}$ & Schuh, Zhang, \& Tian, 2013 & Zahra \& Waheed, 2017 \\
\hline \multirow{2}{*}{$\begin{array}{l}\text { Dhar, } 2016 \\
\text { Javed, Bashir, Rawwas, \& } \\
\text { Arjoon, } 2017\end{array}$} & Tu \& Lu, 2013 & \\
\hline & $\mathrm{Wu}, 2018$ & \\
\hline \multicolumn{3}{|c|}{ Transformational Leadership - Destructive Leadership } \\
\hline \multirow{2}{*}{$\begin{array}{l}\text { Byrne, Dionisi, Barling, } \\
\text { Akers et al. } 2014 \\
\text { Collins \& Jackson, } 2015 \text { (2 } \\
\text { studies) }\end{array}$} & $\begin{array}{l}\text { Johnson, Venus, Lanaj, Mao } \\
\text { \& Chang, } 2012\end{array}$ & Schmidt, 2008 \\
\hline & Ogunfowora, 2009 & Taylor, 2012 \\
\hline \multicolumn{3}{|l|}{ Courtwright, 2012} \\
\hline \multicolumn{3}{|c|}{ Transformational Leadership - Entrepreneurial Leadership } \\
\hline $\begin{array}{l}\text { Newman, Tse, Schwarz \& } \\
\text { Niesen, } 2018\end{array}$ & $\begin{array}{l}\text { Cai, Lysova, Khapova, \& } \\
\text { Bossink, } 2019\end{array}$ & \\
\hline \multicolumn{3}{|c|}{ Transformational Leadership - Humble Leadership } \\
\hline Hwang, 2017 & Owens \& Heckman, 2016 & Oyer, 2015 \\
\hline \multicolumn{3}{|c|}{ Transformational Leadership - Supportive Leadership } \\
\hline \multirow[t]{2}{*}{$\begin{array}{l}\text { Cheung \& Wong, } 2011 \\
\text { Lin, MacLennan, Hunt \& } \\
\text { Cox, } 2015 \\
\text { Contingent Reward - Emp }\end{array}$} & Guild, 2009 & Liaw, Chi \& Chuang, 2010 \\
\hline & hip & \\
\hline
\end{tabular}


Buengeler, Homan, \&

Voelpel, 2016

Ensley, Hmieleski \&

Pearce, 2006

Contingent Reward - Authentic Leadership

Chiaburu, Diaz \& Pitts, $\quad$ Emuwa \& Fields, 2017

2011

Contingent Reward - Destructive Leadership

Bardes, 2009

Taylor, 2012

Ogunfowora, 2009

Contingent Reward - Servant Leadership

Kool \& van Dierendonck, Steinmann, Nubold \& Maier, Washington, Sutton \& 2012
Nguyen, Kuntz, Naswall \&

Malinen, 2016
Sanda \& Arthur, 2017

Zhang, 2013

Sauser, 2014

\section{Contingent Reward - Authoritarian Leadership}

Ensley, Hmieleski \& Khuong \& Hoang, 2015

Pearce, 2006

\section{Contingent Reward - Supportive Leadership}

Malatesta, 1995

Tremblay \& Gibson, 2016

Walumbwa, Wu, \& Orwa, 2008

Authentic Leadership - Humble Leadership

Bharanitharan, Chen, Hwang, 2017

Mao, Chiu, Owens, Brown,

Bahmannia \& Lowe, 2018 \& Liao, 2019

Servant Leadership - Humble Leadership

Hwang, 2017

Ethical Leadership - Humble Leadership

Owens, Yam, Bednar, Mao,

\& Hart, (2019).

LMX - Supportive Leadership

Bhal, Ansari, \& Aafaqi,

2007

Hsu, Chen, Wang, \& Lin,

Schaffer \& Riordan, 2013

Bryant, 2008

White, Campbell, \&

Kacmar, 2012

Gkorezis, 2015

Benevolent Leadership - Supportive Leadership

Chan, 2007

Lee, Jang, \& Lee, 2018

Shu, Chiang, \& Lu, 2018

Chan, 2017

Empowering Leadership - Entrepreneurial Leadership

Newman, Tse, Schwarz \&

Niesen, 2018

Destructive Leadership - Authoritarian Leadership

Aryee, Chen, Sun, \& Dobbs, 2014

Schmidt, 2008

Debrah, 2007

Bell, 2017 


\section{References (All studies included in Meta-Analysis and listed in Appendix C)}

Afsar, B., F. Badir, Y., \& Bin Saeed, B. (2014). Transformational leadership and innovative work behavior. Industrial Management \& Data Systems, 114, 1270-1270. https://doi.org/10.1108/IMDS-05-2014-0152

Akinlade, E. (2014). The dual effect of transformational leadership on individual-and teamlevel creativity (Unpublished Doctoral dissertation). University of Illinois.

Aleksić, D., Mihelič, K. K., Černe, M., \& Škerlavaj, M. (2017). Interactive effects of perceived time pressure, satisfaction with work-family balance (SWFB), and leadermember exchange (LMX) on creativity. Personnel Review, 46, 662-679. https://doi.org/10.1108/PR-04-2015-0085

Al-Madadha, A. (2016). The influence of an integrative approach of empowerment on the creative performance for employees (Unpublished Doctoral dissertation). Cardiff Metropolitan University.

Amundsen, S., \& Martinsen, Ø. (2014a). Self-other agreement in empowering leadership: Relationships with leader effectiveness and subordinates' job satisfaction and turnover intention. The Leadership Quarterly, 25, 784-800. https://doi.org/10.1016/j.leaqua.2014.04.007

Amundsen, S., \& Martinsen, Ø. (2014b). Empowering leadership: Construct clarification, conceptualization, and validation of a new scale. The Leadership Quarterly, 25, 487-511. https://doi.org/10.1016/j.leaqua.2013.11.009

Amundsen, S., \& Martinsen, Ø. (2015). Linking empowering leadership to job satisfaction, work effort, and creativity: The role of self-leadership and psychological empowerment. Journal of Leadership and Organizational Studies, 22, 304-323.

https://doi.org/10.1177/1548051814565819

Arendt, L. A. (2009). Transformational leadership and follower creativity: The moderating 
effect of leader humor. Review of Business Research, 9, 100-106.

Aryee, S., Chen, Z. X., Sun, L-Y., \& Debrah, Y. A. (2007). Antecedents and outcomes of abusive supervision: Test of a trickle-down model. Journal of Applied Psychology, 92, 191-201. https://doi.org/10.1037/0021-9010.92.1.191

Atitumpong, A., \& Badir, Y. F. (2018). Leader-member exchange, learning orientation and innovative work behavior. Journal of Workplace Learning, 30, 32-47. https://doi.org/10.1108/JWL-01-2017-0005

Atwater, L., \& Carmeli, A. (2009). Leader-member exchange, feelings of energy, and involvement in creative work. The Leadership Quarterly, 20, 264-275. https://doi.org/10.1016/j.leaqua.2007.07.009

Audenaert, M., \& Decramer, A. (2016). When empowering leadership fosters creative performance: The role of problem-solving demands and creative personality. Journal of Management and Organization, 24, 4-18. https://doi.org/10.1017/jmo.2016.20

Audenaert, M., Decramer, A., George, B., Verschuere, B., \& Van Waeyenberg, T. (2016). When employee performance management affects individual innovation in public organizations: The role of consistency and LMX. The International Journal of Human Resource Management, 1-20. https://doi.org/10.1080/09585192.2016.1239220

Bae, S. H., Song, J. H., Park, S., \& Kim, H. K. (2013). Influential factors for teachers' creativity: Mutual impacts of leadership, work engagement, and knowledge creation practices. Performance Improvement Quarterly, 26, 33-58. https://doi.org/10.1002/piq.21153

Bagheri, A. (2017). The impact of entrepreneurial leadership on innovation work behavior and opportunity recognition in high-technology SMEs. The Journal of High Technology Management Research, 28, 159-166. https://doi.org/10.1016/j.hitech.2017.10.003 
Bagheri, A., \& Akbari, M. (2018). The impact of entrepreneurial leadership on nurses' innovation behavior. Journal of Nursing Scholarship, 50, 28-35.

Bardes, M. (2009). Aspects of goals and rewards systems as antecedents of abusive supervision: The mediating effect of hindrance stress (Unpublished Doctoral dissertation), University of Central Florida.

Basu, R., \& Green, S. G. (1995). Subordinate performance, leader- subordinate compatibility, and exchange quality in leader- member dyads: A field study. Journal of Applied Social Psychology, 25, 77-92. https://doi.org/10.1111/j.15591816.1995.tb01585.x

Bell, R. M. (2017). The dysfunction junction: The impact of toxic leadership on follower effectiveness (Unpublished Doctoral dissertation), Regent University.

Bhal, K. T., Ansari, M. A., \& Aafaqi, R. (2007). The role of gender match, LMX tenure, and support in leader-member exchange. International Journal of Business and Society, 8, 63-80.

Bharanitharan, K., Chen, Z. X., Bahmannia, S., \& Lowe, K. B. (2018). Is leader humility a friend or foe, or both? An attachment theory lens on leader humility and its contradictory outcomes. Journal of Business Ethics, 1-15. https://doi.org/10.1007/s10551-018-3925-Z

Boerner, S., Eisenbeiss, S. A., \& Griesser, D. (2007). Follower behavior and organizational performance: The impact of transformational leaders. Journal of Leadership \& Organizational Studies, 13, 15-26. https://doi.org/10.1177/10717919070130030201

Bryant, J. L. (2008). Effects of leader relationship quality (LMX), supervisor support, and upward influence in national science foundation industry/university cooperative research centers (Unpublished Doctoral dissertation), Old Dominion University.

Buengeler, C., Homan, A. C., \& Voelpel, S. C. (2016). The challenge of being a young manager: The effects of contingent reward and participative leadership on team- level 
turnover depend on leader age. Journal of Organizational Behavior, 37, 1224-1245. http://dx.doi.org/10.1002/job.2101

Byrne, A., Dionisi, A. M., Barling, J., Akers, A., Robertson, J., Lys, R., Wylie, J., \& Dupre, K. (2014). The depleted leader: The influence of leaders' diminished psychological resources on leadership behaviors. The Leadership Quarterly, 25, 344-357. https://doi.org/10.1016/j.leaqua.2013.09.003

Byun, G., Dai, Y., Lee, S., \& Kang, S. (2016). When does empowering leadership enhance employee creativity? A three-way interaction test. Social Behavior and Personality: An international journal, 44, 1555-1564. https://doi.org/10.2224/sbp.2016.44.9.1555

Cai, W., Lysova, E. I., Khapova, S. N., \& Bossink, B. A. (2019). Does entrepreneurial leadership foster creativity among employees and teams? The mediating role of creative efficacy beliefs. Journal of Business and Psychology, 34, 203-217. https://doi.org/10.1007/s10869-018-9536-y

Carmeli, A., Sheaffer, Z., Binyamin, G., Reiter-Palmon, R., \& Shimoni, T. (2014). Transformational leadership and creative problem-solving: The mediating role of psychological safety and reflexivity. Journal of Creative Behavior, 48, 115-135. https://doi.org/10.1002/jocb.43

Černe, M., Jaklič, M., \& Škerlavaj, M. (2013). Authentic leadership, creativity, and innovation: A multilevel perspective. Leadership, 9, 63-85. https://doi.org/10.1177/1742715012455130

Chan, C. H. (2007). Paternalistic leadership styles and follower performance: Examining mediating variables in a multi-level model (Unpublished Doctoral dissertation), The Hong Kong Polytechnic University.

Chan, S. C. (2017). Benevolent leadership, perceived supervisory support, and subordinates' performance: The moderating role of psychological empowerment. Leadership \& 
Organization Development Journal, 38, 897-911. http://dx.doi.org/10.1108/LODJ-092015-0196

Chang, J., Bai, X., \& Li, J. J. (2015). The influence of leadership on product and process innovations in China: The contingent role of knowledge acquisition capability. Industrial Marketing Management, 50, 18-29. https://doi.org/10.1016/j.indmarman.2015.04.014

Chang, J., \& Teng, C. (2017). Intrinsic or extrinsic motivations for hospitality employees' creativity: The moderating role of organization-level regulatory focus. International Journal of Hospitality Management, 60, 133-141.

https://doi.org/10.1016/j.ijhm.2016.10.003

Charbonnier-Voirin, A., El Akremi, A., \& Vandenberghe, C. (2010). A multilevel model of transformational leadership and adaptive performance and the moderating role of climate for innovation. Group \& Organization Management, 35, 699-726. https://doi.org/10.1177/1059601110390833

Chaudhary, R., \& Panda, C. (2018). Authentic leadership and creativity: The intervening role of psychological meaningfulness, safety and work engagement. International Journal of Productivity and Performance Management, 67, 2071-2088. https://doi.org/10.1108/IJPPM-02-2018-0082

Chaubey, A., Sahoo, C. K., \& Khatri, N. (2019). Relationship of transformational leadership with employee creativity and organizational innovation: A study of mediating and moderating influences. Journal of Strategy and Management, 12, 61-82. https://doi.org/10.1108/JSMA-07-2018-0075

Chiaburu, D. S., Diaz, I., \& Pitts, V. E. (2011). Social and economic exchanges with the organization: do leader behaviors matter? Leadership \& Organization Development Journal, 32, 442-461. https://doi.org/10.1108/01437731111146569

Chen, G., Farh, J. L., Campbell-Bush, E. M., Wu, Z., \& Wu, X. (2013). Teams as innovative 
systems: Multilevel motivational antecedents of innovation in R\&D teams. Journal of Applied Psychology, 98, 1018-1027. https://doi.org/10.1037/a0032663

Chen, A. S., \& Hou, Y. (2016). The effects of ethical leadership, voice behavior and climates for innovation on creativity: A moderated mediation examination. The Leadership Quarterly, 27, 1-13. https://doi.org/10.1016/j.leaqua.2015.10.007

Chen, T., Li, F., \& Leung, K. (2016). When does supervisor support encourage innovative behavior? Opposite moderating effects of general self- efficacy and internal locus of control. Personnel Psychology, 69, 123-158. https://doi.org/10.1111/peps.12104

Chen, G., Sharma, P. N., Edinger, S. K., Shapiro, D. L., \& Farh, J.-L. (2011). Motivating and demotivating forces in teams: Cross-level influences of empowering leadership and relationship conflict. Journal of Applied Psychology, 96, 541-557. https://doi.org/10.1037/a0021886

Cheung, M. F., \& Wong, C. S. (2011). Transformational leadership, leader support, and employee creativity. Leadership \& Organization Development Journal, 32, 656-672. https://doi.org/10.1108/01437731111169988

Choi, J. N., Anderson, T. A., \& Veillette, A. (2009). Contextual inhibitors of employee creativity in organizations the insulating role of creative ability. Group \& Organization Management, 34, 330-357. https://doi.org/10.1177/1059601108329811

Choi, J. N. (2004). Individual and contextual predictors of creative performance: The mediating role of psychological processes. Creativity Research Journal, 16, 187-199. https://doi.org/10.1080/10400419.2004.9651452

Choi, S. B., Kim, K., Ullah, S. E., \& Kang, S. W. (2016). How transformational leadership facilitates innovative behavior of Korean workers: Examining mediating and moderating processes. Personnel Review, 45, 459-479. https://doi.org/10.1108/PR-03-2014-0058 
Chow, I. (2018). The mechanism underlying the empowering leadership-creativity relationship. Leadership \& Organization Development Journal, 39, 202217. https://doi.org/10.1108/LODJ-03-2016-0060.

Chughtai, A. A. (2016). Can ethical leaders enhance their followers' creativity? Leadership, 12, 230-249. https://doi.org/10.1177/1742715014558077

Clegg, C., Unsworth, K., Epitropaki, O., \& Parker, G. (2002). Implicating trust in the innovation process†. Journal of Occupational and Organizational Psychology, 75, 409422. https://doi.org/10.1348/096317902321119574

Collins, M. D., \& Jackson, C. J. (2015). A process model of self-regulation and leadership: How attentional resource capacity and negative emotions influence constructive and destructive leadership. The Leadership Quarterly, 26, 386-401. https://doi.org/10.1016/j.leaqua.2015.02.005

Courtright, S. H. (2012). Fired up or burned out? Exploring the effects of leadership challenge demands on leadership behaviors through engagement and burnout (Unpublished Doctoral dissertation). University of Iowa (UMI No. 3628471).

Craig, J. T. (2015). Antecedents of individual innovative behavior: Examining transformational leadership, creative climate, role ambiguity, risk propensity, and psychological empowerment (Unpublished Doctoral dissertation). Alliant International University.

Darvishmotevali, M. (2019). Decentralization and innovative behavior: The moderating role of supervisor support. International Journal of Organizational Leadership, 8, 31-45. https://ssrn.com/abstract=3337656

De Jong, J. P. J., \& Den Hartog, D. N. (2010). Measuring innovative work behavior. Creativity and Innovation Management, 19, 23-36. https://doi.org/10.1111/j.14678691.2010.00547.x 
Dedahanov, A. T., Bozorov, F., \& Sung, S. (2019). Paternalistic leadership and innovative behavior: Psychological empowerment as a mediator. Sustainability, 11, 1770-1784. https://doi.org/10.3390/su11061770

Dedahanov, A. T., Lee, D. H., Rhee, J. \& Yoon, J. (2016). Entrepreneur's paternalistic leadership style and creativity: The mediating role of employee voice. Management Decision, 54, 2310-2324. https://doi.org/10.1108/MD-11-2015-0537

Denti, L. (2011). Leadership and innovation: how and when do leaders influence innovation in $R \& D$ Teams? (Unpublished doctoral dissertation). University of Gothenburg, Sweden.

Denti, L., \& Hemlin, S. (2016). Modelling the link between leader-member exchange and individual innovation in R\&D. International Journal of Innovation Management, 20, 1650038-1-23. https://doi.org/10.1142/S1363919616500389

Dhar, R. L. (2016). Ethical leadership and its impact on service innovative behavior: The role of LMX and job autonomy. Tourism Management, 57, 139-148. https://doi.org/10.1016/j.tourman.2016.05.011

Do, H., Budhwar, P. S., \& Patel, C. (2018). Relationship between innovation- led HR policy, strategy, and firm performance: A serial mediation investigation. Human Resource Management, 57, 1271-1284. https://doi.org/10.1002/hrm.21903

Dobbs, J. M. (2014). The relationship between perceived toxic leadership styles, leader effectiveness, and organizational cynicism (Unpublished Doctoral dissertation), University of San Diego.

Dong, Y., Bartol, K. M., Zhang, Z., \& Li, C. (2017). Enhancing employee creativity via individual skill development and team knowledge sharing: Influences of dual-focused transformational leadership. Journal of Organizational Behavior, 38, 439-458. https://doi.org/10.1002/job.2134 
Duan, S., Liu, Z., \& Che, H. (2018). Mediating influences of ethical leadership on employee creativity. Social Behavior and Personality: An International Journal, 46, 323-337. https://doi.org/10.2224/sbp.6160

Elenkov, D. S., Judge, W., \& Wright, P. (2005). Strategic leadership and executive innovation influence: An international multi- cluster comparative study. Strategic Management Journal, 26, 665-682. https://doi.org/10.1002/smj.469

Elenkov, D. S., \& Manev, I. M. (2005). Top management leadership and influence on innovation: The role of sociocultural context. Journal of Management, 31, 381-402. https://doi.org/10.1177/0149206304272151

Eisenbeiß, S. A., \& Boerner, S. (2013). A double- edged sword: Transformational leadership and individual creativity. British Journal of Management, 24, 54-68. https://doi.org/10.1111/j.1467-8551.2011.00786.x

Emuwa, A., \& Fields, D. (2017). Authentic leadership as a contemporary leadership model applied in Nigeria. African Journal of Economic and Management Studies, 8, 296-313. https://doi.org/10.1108/AJEMS-06-2016-0092

Ensley, M. D., Hmieleski, K. M., \& Pearce, C. L. (2006). The importance of vertical and shared leadership within new venture top management teams: Implications for the performance of startups. The Leadership Quarterly, 17, 217-231. https://doi.org/10.1016/j.leaqua.2006.02.002

Fatima, T., Safdar, S., \& Jahanzeb, S. (2017). Participative leadership and employee creativity: Moderating role of need for achievement. International Journal of Business \& Management, 12, 1-14.

Feng, J., Zhang, Y., Liu, X., Zhang, L., \& Han, X. (2016). Just the right amount of ethics inspires creativity: A cross-level investigation of ethical leadership, intrinsic motivation, 
and employee creativity. Journal of Business Ethics, 1-14.

https://doi.org/10.1007/s10551-016-3297-1

George, J. M., \& Zhou, J. (2007). Dual tuning in a supportive context: Joint contributions of positive mood, negative mood, and supervisory behaviors to employee creativity. Academy of Management Journal, 50(3), 605-622. https://doi.org/10.5465/amj.2007.25525934

Ghafoor, A., Qureshi, T., Azeemi, H., \& Hijazi, S. (2011). Mediating role of creative selfefficacy. African Journal of Business Management, 5, 11093-11103. https://doi.org/10.5897/AJBM11.876

Gilmore, P. L., Hu, X., Wei, F., Tetrick, L. E., \& Zaccaro, S. J. (2013). Positive affectivity neutralizes transformational leadership's influence on creative performance and organizational citizenship behaviors. Journal of Organizational Behavior, 34, 10611075. https://doi.org/10.1002/job.1833

Gkorezis, P. (2015). Supervisor support and pro-environmental behavior: the mediating role of LMX. Management Decision, 53, 1045-1060. https://doi.org/10.1108/MD-06-20140370

Gkorezis, P. (2016). Principal empowering leadership and teacher innovative behavior: a moderated mediation model. International journal of educational management, 30 , 1030-1044. https://doi.org/10.1108/IJEM-08-2015-0113

Golden III, J. H. (2016). Examining relationships between transformational leadership and employee creativity and innovation performance: The moderator effects of organizational culture (Unpublished Doctoral dissertation). Northcentral University.

Gong, Y., Huang, J.C., \& Farh, J. L. (2009). Employee learning orientation, transformational leadership, and employee creativity: The mediating role of employee creative selfefficacy. Academy of Management Journal, 52, 765-778. 
https://doi.org/10.5465/AMJ.2009.43670890

Gong, Y., Kim, T. Y., Lee, D. R., \& Zhu, J. (2013). A multilevel model of team goal orientation, information exchange, and creativity. Academy of Management Journal, 56, 827-851. https://doi.org/10.5465/amj.2011.0177

Gross, R. (2016). The impact of leadership styles on employee entrepreneurial orientation and innovative behavior: A comparative analysis of American and Indian immigrant Entrepreneurs (Unpublished Doctoral dissertation). Regent University.

Gu, J., He, C., \& Liu, H. (2017). Supervisory styles and graduate student creativity: the mediating roles of creative self-efficacy and intrinsic motivation. Studies in Higher Education, 42, 721-742. https://doi.org/10.1080/03075079.2015.1072149

Gu, J., Song, J., \& Wu, J. (2016). Abusive supervision and employee creativity in China: Departmental identification as mediator and face as moderator. Leadership \& Organization Development Journal, 37, 1187-1204. https://doi.org/10.1108/LODJ-022015-0021

Gu, Q., Tang, T.L.P. \& Jiang, W. (2015). Does moral leadership enhance employee creativity? Employee identification with leader and leader-member exchange (LMX) in the Chinese context. Journal of Business Ethics, 126, 513-529. https://doi.org/10.1007/s10551-013-1967-9

Gu, J., Wang, G., Liu, H., Song, D., \& He, C. (2018). Linking authoritarian leadership to employee creativity: the influences of leader-member exchange, team identification and power distance. Chinese Management Studies, 12, 384-406. https://doi.org/10.1108/CMS-10-2017-0294

Guild, D. P. (2009). Antecedents and consequences of supervisory support: The moderating affects of perceived organizational status of the supervisor (Unpublished Doctoral dissertation), Webster University. 
Gumusluoglu, L., \& Ilsev, A. (2009). Transformational leadership, creativity, and organizational innovation. Journal of Business Research, 62, 461-473. https://doi.org/10.1016/j.jbusres.2007.07.032

Günzel-Jensen, F., Hansen, J. R., Jakobsen, M. L. F., \& Wulff, J. (2018). A two-pronged approach? Combined leadership styles and innovative behavior. International Journal of Public Administration, 41, 957-970. https://doi.org/10.1080/01900692.2017.1303711

Guo, L., Decoster, S., Babalola, M. T., De Schutter, L., Garba, O. A., \& Riisla, K. (2018). Authoritarian leadership and employee creativity: The moderating role of psychological capital and the mediating role of fear and defensive silence. Journal of Business Research, 92, 219-230. https://doi.org/10.1016/j.jbusres.2018.07.034

Han, G. H., Harms, P. D., \& Bai, Y. (2017). Nightmare bosses: The impact of abusive supervision on employees' sleep, emotions, and creativity. Journal of Business Ethics, 145, 21-31. https://doi.org/10.1007/s10551-015-2859-y

Harris, T. B., Li, N., Boswell, W. R., Zhang, X. A., \& Xie, Z. (2014). Getting what's new from newcomers: Empowering leadership, creativity, and adjustment in the socialization context. Personnel Psychology, 67, 567-604. https://doi.org/10.1111/peps.12053

Hassanzadeh, J. F. (2014). Leader-member exchange, Creative work involvement: The Importance of knowledge sharing. Iranian Journal of Management Studies, 7, 391-412.

Henker, N. (2013). Antecedents of employee creativity (Unpublished Doctoral dissertation). University of Konstanz.

Henker, N., Sonnentag, S., \& Unger, D. (2015). Transformational leadership and employee creativity: The mediating role of promotion focus and creative process engagement. Journal of Business and Psychology, 30, 235-247. https://doi.org/10.1007/s10869-0149348-7

Hirst, G., Van Dick, R., \& Van Knippenberg, D. (2009). A social identity perspective on 
leadership and employee creativity. Journal of Organizational Behavior, 30, 963-982. https://doi.org/10.1002/job.600

Hon, A. H. (2011). Enhancing employee creativity in the Chinese context: The mediating role of employee self-concordance. International Journal of Hospitality Management, 30, 375-384. https://doi.org/10.1016/j.ijhm.2010.06.002

Hon, A. H. Y., Bloom, M., \& Crant, J. M. (2014). Overcoming resistance to change and enhancing creative performance. Journal of Management, 40, 919-941. https://doi.org/10.1177/0149206311415418

Hsu, B. F., Chen, W. Y., Wang, M. L., \& Lin, Y. Y. (2010). Explaining supervisory support to work-family conflict: The perspectives of Guanxi, LMX, and emotional intelligence. Journal of Technology Management in China, 5, 40-54. http://dx.doi.org/10.1108/17468771011032787

Huang, L., Krasikova, D. V., \& Liu, D. (2016). I can do it, so can you: The role of leader creative self-efficacy in facilitating follower creativity. Organizational Behavior and Human Decision Processes, 132, 49-62. https://doi.org/10.1016/j.obhdp.2015.12.002

Hussain, H., Talib, N., \& Shah, I. (2014). Exploring the impact of transformational leadership on process innovation and product innovation: A case of Iraqi public universities. Asian Social Science, 10, 168-174. https://doi.org/10.5539/ass.v10n21p168

Hwang, S. J. (2013). Influence of leader behaviors on creativity: A comparative study between South Korea and the United States (Unpublished Doctoral dissertation). University of Minnesota.

Hwang, J, (2017). Asian American leadership: Does leadership style matter? (Unpublished Doctoral dissertation). San Diego State University. 
Iskandarani, K. M. (2017). Assessing the impact of transformational leadership, organizational climate, and personality on individual innovativeness at work (Unpublished Doctoral dissertation). Eastern Michigan University.

Jaffer, S. (2013) Harnessing innovation in the 21 st century: The impact of leadership styles. (Unpublished doctoral dissertation). George Washington University.

Jafri, M. H. (2018). Moderating role of job autonomy and supervisor support in trait emotional intelligence and employee creativity relationship. Vision, 22, 253-263. https://doi.org/10.1177/0972262918785960

Jaiswal, N. K., \& Dhar, R. L. (2016). Fostering employee creativity through transformational leadership: Moderating role of creative self-efficacy. Creativity Research Journal, 28, 367-371. https://doi.org/10.1080/10400419.2016.1195631

Jaiswal, N. K., \& Dhar, R. L. (2017). The influence of servant leadership, trust in leader and thriving on employee creativity. Leadership \& Organization Development Journal, 38, 2-21. https://doi.org/10.1108/LODJ-02-2015-0017

Janssen, O. (2005). The joint impact of perceived influence and supervisor supportiveness on employee innovative behavior. Journal of Occupational and Organizational Psychology, 78, 573-579. ttps://doi.org/10.1348/096317905X25823

Janssen, O., \& Van Yperen, N. (2004). Employees' goal orientations, the quality of leadermember exchange, and the outcomes of job performance and job satisfaction. Academy of Management Journal, 47, 369-384. https://doi.org/10.2307/20159587

Jaramillo, F., Grisaffe, D. B., Chonko, L. B., \& Roberts, J. A. (2009). Examining the impact of servant leadership on salesperson's turnover intention. Journal of Personal Selling \& Sales Management, 29, 351-365. https://doi.org/10.2753/PSS0885-3134290404

Jaussi, K. S., \& Dionne, S. D. (2003). Leading for creativity: The role of unconventional leader behavior. The Leadership Quarterly, 14, 475-498. https://doi.org/10.1016/S1048- 
9843(03)00048-1

Javed, B., Bashir, S., Rawwas, M. Y. A., \& Arjoon, S. (2017). Islamic work ethic, innovative work behavior, and adaptive performance: The mediating mechanism and an interacting effect. Current Issues in Tourism, 20, 647-663. https://doi.org/10.1080/13683500.2016.1171830

Javed, B., Khan, A. A., Bashir, S., \& Arjoon, S. (2017). Impact of ethical leadership on creativity: The role of psychological empowerment. Current Issues in Tourism, 20, 839851. https://doi.org/10.1080/13683500.2016.1188894

Javed, B., Rawwas, M. Y., Khandai, S., Shahid, K., \& Tayyeb, H. H. (2018). Ethical leadership, trust in leader and creativity: The mediated mechanism and an interacting effect. Journal of Management \& Organization, 24, 388-405. https://doi.org/10.1017/jmo.2017.56

Jiang, W., \& Gu, Q. (2016). How abusive supervision and abusive supervisory climate influence salesperson creativity and sales team effectiveness in China. Management Decision, 54, 455-475. https://doi.org/10.1108/MD-07-2015-0302

Jiang, W., Gu, Q., \& Tang, T. L. (2017). Do victims of supervisor bullying suffer from poor creativity? Social cognitive and social comparison perspectives. Journal of Business Ethics, 1-20. https://doi.org/10.1007/s10551-017-3660-x

Jiang, J., \& Yang, B. (2015). Roles of creative process engagement and leader-member exchange in critical thinking and employee creativity. Social Behavior and Personality: An International Journal, 43, 1217-1231. https://doi.org/10.2224/sbp.2015.43.7.1217

Johnson, R. E., Venus, M., Lanaj, K., Mao, C., \& Chang, C. H. (2012). Leader identity as an antecedent of the frequency and consistency of transformational, consideration, and abusive leadership behaviors. Journal of Applied Psychology, 97, 1262-1272. https://doi.org/10.1037/a0029043 
Joo, B. K. B., \& Bennett III, R. H. (2018). The influence of proactivity on creative behavior, organizational commitment, and job performance: Evidence from a Korean multinational. Journal of International \& Interdisciplinary Business Research, 5, 1-20.

Joo, B. K., Yang, B., \& McLean, G. N. (2014). Employee creativity: The effects of perceived learning culture, leader-member exchange quality, job autonomy, and proactivity. Human Resource Development International, 17, 297-317. https://doi.org/10.1080/13678868.2014.896126

Jyoti, J., \& Dev, M. (2015). The impact of transformational leadership on employee creativity: The role of learning orientation. Journal of Asia Business Studies, 9, 78-98. https://doi.org/10.1108/JABS-03-2014-0022

Kang, J. H. (2013). CEOs' transformational leadership and managers' innovative behavior: The investigation of intervening effects in an entrepreneurial context (Unpublished Doctoral dissertation). The George Washington University.

Kang, J. H., Solomon, G. T., \& Choi, D. Y. (2015). CEOs' leadership styles and managers' innovative behavior: Investigation of intervening effects in an entrepreneurial context. Journal of Management Studies, 52, 531-554. https://doi.org/10.1111/joms.12125

Kao, P. J., Pai, P., Lin, T., \& Zhong, J.Y. (2015). How transformational leadership fuels employees' service innovation behavior. The Service Industries Journal, 35, 448-466. https://doi.org/10.1080/02642069.2015.1015519

Karakitapoğlu-Aygün, Z., Gumusluoglu, L., \& Scandura, T. A. (2019). How do different faces of paternalistic leaders facilitate or impair task and innovative performance? Opening the black box. Journal of Leadership \& Organizational Studies, 1-15. https://doi.org/10.1177/1548051819833380 
Karatepe, O. M., Ozturk, A., \& Kim, T. T. (2019). Servant leadership, organizational trust, and bank employee outcomes. The Service Industries Journal, 39, 86-108. https://doi.org/10.1080/02642069.2018.1464559

Kark, R., Van Dijk, D., \& Vashdi, D. R. (2018). Motivated or demotivated to be creative: The role of self- regulatory focus in transformational and transactional leadership processes. Applied Psychology, 67, 186-224. https://doi.org/10.1111/apps.12122

Khalili, A. (2016). Linking transformational leadership, creativity, innovation, and innovation-supportive climate. Management Decision, 54, 2277-2293. https://doi.org/10.1108/MD-03-2016-0196

Khalili, A. (2018). Creativity and innovation through LMX and personal initiative. Journal of Organizational Change Management, 31, 323-333. https://doi.org/10.1108/JOCM-092016-0183

Khuong, M. N., \& Hoang, D. T. (2015). The effects of leadership styles on employee motivation in auditing companies in Ho Chi Minh City, Vietnam. International Journal of Trade, Economics and Finance, 6, 210-217

Kim, J. G. (2000). A study of relationships among work motivation, problem-solving style, leadership style, and team climate on creative behavior in the South Korean workplace (Unpublished doctoral dissertation). University of Missouri-Columbia.

Kim, S. L. (2019). The interaction effects of proactive personality and empowering leadership and close monitoring behavior on creativity, Creative and Innovation Management, https://doi.org/10.1111/caim.12304

Kim, J. G., \& Lee, S.-Y. (2011). Effects of transformational and transactional leadership on employees' creative behavior: Mediating effects of work motivation and job satisfaction. Asian Journal of Technology Innovation, 19, 233-247. https://doi.org/10.1080/19761597.2011.632590 
Kim, M. S., \& Koo, D. W. (2017). Linking LMX, engagement, innovative behavior, and job performance in hotel employees. International Journal of Contemporary Hospitality Management, 29, 3044-3062. https://doi.org/10.1108/IJCHM-06-2016-0319

Kollmann, T., Stöckmann, C., \& Krell, P. (2011). One style fits all? Integrating achievement motives in the transformational leadership-dependency-creativity linkage. Paper session presented at the meeting of the International Council for Small Business (ICSB), Stockholm, Sweden.

Kong, M., Xu, H., Zhou, A., \& Yuan, Y. (2019). Implicit followership theory to employee creativity: The roles of leader-member exchange, self-efficacy and intrinsic motivation. Journal of Management and Organization, 25, 81-95. https://doi.org/10.1017/jmo.2017.18

Kool, M., \& van Dierendonck, D. (2012). Servant leadership and commitment to change, the mediating role of justice and optimism. Journal of Organizational Change Management, 25, 422-433. https://doi.org/10.1108/09534811211228139

Koseoglu, G., Liu, Y., \& Shalley, C. E. (2017). Working with creative leaders: Exploring the relationship between supervisors' and subordinates' creativity. The Leadership Quarterly, 28, 798-811. https://doi.org/10.1016/j.leaqua.2017.03.002

Krog, C. L., \& Govender, K. (2015). The relationship between servant leadership and employee empowerment, commitment, trust and innovative behavior: A project management perspective. SA Journal of Human Resource Management, 13, 1-12. https://doi.org/10.4102/sajhrm.v13i1.712

Lee, J. (2008). Effects of leadership and leader-member exchange on innovativeness. Journal of Managerial Psychology, 23, 670-687. https://doi.org/10.1108/02683940810894747

Lee, J. Y., Jang, S. H., \& Lee, S. Y. (2018). Paternalistic leadership and knowledge sharing with outsiders in emerging economies: Based on social exchange relations within the 
China context. Personnel Review, 47, 1094-1115. https://doi.org/10.1108/PR-03-20170068

Lee, K., Scandura, T., Kim, Y., Joshi, K., \& Lee, J. (2012). Examining leader-member exchange as a moderator of the relationship between emotional intelligence and creativity of software developers. Engineering Management Research, 1, 15-28. https://doi.org/10.5539/emr.v1n1p15

Lee, S., Yun, S., \& Srivastava, A. (2013). Evidence for a curvilinear relationship between abusive supervision and creativity in South Korea. The Leadership Quarterly, 24, 724731. https://doi.org/10.1016/j.leaqua.2013.07.002

Li, H., Chen, T., \& Cao, G. (2017). How high-commitment work systems enhance employee creativity: A mediated moderation model. Social Behavior and Personality: An International Journal, 45, 1437-1450. https://doi.org/10.2224/sbp.6514

Li, V., Mitchell, R., \& Boyle, B. (2016). The divergent effects of transformational leadership on individual and team innovation. Group \& Organization Management, 41, 66-97. https://doi.org/10.1177/1059601115573792

Li, F., Yu, K. F., Yang, J., Qi, Z., \& Fu, J. H. Y. (2014). Authentic leadership, traditionality, and interactional justice in the Chinese context. Management and Organization Review, 10, 249-273. https://doi.org/10.1111/more.12027

Li, M., \& Zhang, P. (2016). Stimulating learning by empowering leadership: Can we achieve cross-level creativity simultaneously?. Leadership \& Organization Development Journal, 37, 1168-1186. https://doi.org/10.1108/LODJ-01-2015-0007

Li, C., Zhao, H., \& Begley, T. M. (2015). Transformational leadership dimensions and employee creativity in china: A cross-level analysis. Journal of Business Research, 68, 1149-1156. https://doi.org/10.1016/j.jbusres.2014.11.009 
Liao, S. H., Chen, C. C., \& Hu, D. C. (2018). The role of knowledge sharing and LMX to enhance employee creativity in theme park work team: A case study of Taiwan. International Journal of Contemporary Hospitality Management, 30, 2343-2359. https://doi.org/10.1108/IJCHM-09-2016-0522

Liao, E. Y., \& Chun, H. (2016). Supervisor monitoring and subordinate innovation. Journal of Organizational Behavior, 37(2), 168-192. https://doi.org/10.1002/job.2035

Liao, H., Liu, D., \& Loi, R. (2010). Looking at both sides of the social exchange coin: A social cognitive perspective on the joint effects of relationship quality and differentiation on creativity. Academy of Management Journal, 53, 1090-1109. https://doi.org/10.5465/amj.2010.54533207

Liaw, Y. J., Chi, N. W., \& Chuang, A. (2010). Examining the mechanisms linking transformational leadership, employee customer orientation, and service performance: The mediating roles of perceived supervisor and coworker support. Journal of Business and Psychology, 25, 477-492. http://dx.doi.org/10.1007/s10869-009-9145-x

Liden, R. C., Wayne, S. J., Meuser, J. D., Hu, J., Wu, J., \& Liao, C. (2015). Servant leadership: Validation of a short form of the SL-28. The Leadership Quarterly, 26, 254269. https://doi.org/10.1016/j.leaqua.2014.12.002

Lim, H. S., \& Choi, J. N. (2009). Testing an alternative relationship between individual and contextual predictors of creative performance. Social Behavior and Personality: An International Journal, 37, 117-135. https://doi.org/10.2224/sbp.2009.37.1.117

Lin, P. Y., MacLennan, S., Hunt, N., \& Cox, T. (2015). The influences of nursing transformational leadership style on the quality of nurses' working lives in Taiwan: A cross-sectional quantitative study. BMC nursing, 14, 33-42. http://dx.doi.org/10.1186/s12912-015-0082-x 
Lin, W., Ma, J., Zhang, Q., Li, J. C., \& Jiang, F. (2018). How is benevolent leadership linked to employee creativity? The mediating role of leader-member exchange and the moderating role of power distance orientation. Journal of Business Ethics, 152, 10991115. https://doi.org/10.1007/s10551-016-3314-4

Liu, D., Liao, H., \& Loi, R. (2012). The dark side of leadership: A three-level investigation of the cascading effect of abusive supervision on employee creativity. Academy of Management Journal, 55, 1187-1212. https://doi.org/10.5465/amj.2010.0400

Liu, D., Gong, Y., Zhou, J., \& Huang, J. (2017). Human resource systems, employee creativity, and firm innovation: The moderating role of firm ownership. Academy of Management Journal, 60, 1164-1188. https://doi.org/10.5465/amj.2015.0230

Liu, W., Zhang, P., Liao, J., Hao, P., \& Mao, J. (2016). Abusive supervision and employee creativity: The mediating role of psychological safety and organizational identification. Management Decision, 54, 130-147. https://doi.org/10.1108/MD-09-2013-0443

Lu, X., \& Sun, J. M. (2017). Multiple pathways linking leader-member exchange to work effort. Journal of Managerial Psychology, 32, 270-283. http://dx.doi.org/10.1108/JMP01-2016-0011

Luu, M. A. (2017). The moderating role of transformational leadership and perceived organizational support in the relationship between openness to experience and creativity (Unpublished Doctoral dissertation). San Jose State University.

Ma, Y., Cheng, W., Ribbens, B. A., Zhou, J. (2013). Linking ethical leadership to employee creativity: Knowledge sharing and self-efficacy as mediators. Social Behavior and Personality: An International Journal, 41, 1409-1419. https://doi.org/10.2224/sbp.2013.41.9.1409 
Malatesta, R. M. (1995). Understanding the dynamics of organizational and supervisory commitment using a social exchange framework (Unpublished Doctoral dissertation), Wayne State University.

Malik, N., Dhar, R. L., \& Handa, S. C. (2016). Authentic leadership and its impact on creativity of nursing staff: A cross sectional questionnaire survey of Indian nurses and their supervisors. International journal of nursing studies, 63, 28-36. https://doi.org/10.1016/j.ijnurstu.2016.08.004

Malingumu, W., Stouten, J., Euwema, M., \& Babyegeya, E. (2016). Servant leadership, organizational citizenship behavior and creativity: The mediating role of team-member exchange. Psychologica Belgica, 56, 342-356. https://doi.org/10.5334/pb.326

Mansur, J. A. (2016). On paternalistic leadership fit: exploring cross-cultural endorsement, leader-follower fit, and the boundary role of organizational culture (Unpublished Doctoral dissertation). Escola Brasileira de Administração Pública e de Empresas, Centro de Formação Acadêmica e Pesquisa.

Mao, J., Chiu, C. Y., Owens, B. P., Brown, J. A., \& Liao, J. (2019). Growing Followers: Exploring the Effects of Leader Humility on Follower Self- Expansion, Self- Efficacy, and Performance. Journal of Management Studies, 56, 343-371. http://dx.doi.org/10.1111/joms.12395

Martinaityte, I., \& Sacramento, C. A. (2013). When creativity enhances sales effectiveness: The moderating role of leader-member exchange. Journal of Organizational Behavior, 34, 974-994. https://doi.org/10.1002/job.1835

Mehmood, S. (2016). Impact of ethical leadership on employee creativity: Mediating role of trust and moderating role of creative self-efficacy. Jinnah Business Review, 4, 65-74. 
Meng, H., Cheng, Z. C., \& Guo, T. C. (2016). Positive team atmosphere mediates the impact of authentic leadership on subordinate creativity. Social Behavior and Personality: an international journal, 44, 355-368. http://dx.doi.org/10.2224/sbp.2016.44.3.355

Meng, Y., Tan, J., \& Li, J. (2017). Abusive supervision by academic supervisors and postgraduate research students' creativity: The mediating role of leader-member exchange and intrinsic motivation. International Journal of Leadership in Education, 20, 605-617. https://doi.org/10.1080/13603124.2017.1304576

Ma, X., \& Jiang, W. (2018). Transformational leadership, transactional leadership, and employee creativity in entrepreneurial firms. The Journal of Applied Behavioral Science, 54, 302-324. https://doi.org/10.1177/0021886318764346

Miao, Q., Newman, A., \& Lamb, P. (2012). Transformational leadership and the work outcomes of Chinese migrant workers: The mediating effects of identification with leader. Leadership, 8, 377-395. https://doi.org/10.1177/1742715012444055

Miao, C. F., \& Wang, G. (2016). The differential effects of functional vis-à-vis relational customer orientation on salesperson creativity. Journal of Business Research, 69(, 60216030. https://doi.org/10.1016/j.jbusres.2016.05.017

Mittal, S., \& Dhar, R. L. (2015). Transformational leadership and employee creativity: mediating role of creative self-efficacy and moderating role of knowledge sharing. Management Decision, 53, 894-910. https://doi.org/10.1108/MD-07-2014-0464

Mahmood, M., Uddin, M. A., \& Fan, L. (2019). The influence of transformational leadership on employees' creative process engagement: A multi-level analysis. Management Decision, 57, 741-764. https://doi.org/10.1108/MD-07-2017-0707

Moss, S. A., \& Ritossa, D. A. (2007). The impact of goal orientation on the association between leadership style and follower performance, creativity and work attitudes. Leadership, 3, 433-456. https://doi.org/10.1177/1742715007082966 
Mubarak, F., \& Noor, A. (2018). Effect of authentic leadership on employee creativity in project-based organizations with the mediating roles of work engagement and psychological empowerment. Cogent Business \& Management, 5, 1-14. https://doi.org/10.1080/23311975.2018.1429348

Muñoz-Doyague, M. F., \& Nieto, M. (2012). Individual creativity performance and the quality of interpersonal relationships. Industrial Management \& Data Systems, 112, 125145. https://doi.org/10.1108/02635571211193671

Naseer, S., Raja, U., Syed, F., Donia, M. B. L., \& Darr, W. (2016). Perils of being close to a bad leader in a bad environment: Exploring the combined effects of despotic leadership, leader member exchange, and perceived organizational politics on behaviors. The Leadership Quarterly, 27, 14-33. https://doi.org/10.1016/j.leaqua.2015.09.005

Neubert, M. J., Hunter, E. M., \& Tolentino, R. C. (2016). A servant leader and their stakeholders: When does organizational structure enhance a leader's influence? The Leadership Quarterly, 27, 896-910. https://doi.org/10.1016/j.leaqua.2016.05.005

Neubert, M. J., Kacmar, K. M., Carlson, D. S., Chonko, L. B., \& Roberts, J. A. (2008). Regulatory focus as a mediator of the influence of initiating structure and servant leadership on employee behavior. Journal of Applied Psychology, 93, 1220 - 1233. https://doi.org/10.1037/a0012695

Newman, A., Neesham, C., Manville, G., \& Tse, H. H. M. (2017). Examining the influence of servant and entrepreneurial leadership on the work outcomes of employees in social enterprises. The International Journal of Human Resource Management, 1-22. https://doi.org/10.1080/09585192.2017.1359792

Newman, A., Herman, H. M., Schwarz, G., \& Nielsen, I. (2018). The effects of employees' creative self-efficacy on innovative behavior: The role of entrepreneurial leadership. Journal of Business Research, 89, 1-9. https://doi.org/10.1016/j.jbusres.2018.04.001 
Nguyen, D. (2017). Intrinsic property of trait activation: the case of openness to experience and creative behavior in the context of transformational leadership and job complexity. (Unpublished master dissertation). Illinois State University.

Nguyen, Q., Kuntz, J. R., Näswall, K., \& Malinen, S. (2016). Employee resilience and leadership styles: The moderating role of proactive personality and optimism. New Zealand Journal of Psychology (Online), 45, 13-21.

Odoardi, C., Montani, F., Boudrias, J., \& Battistelli, A. (2015). Linking managerial practices and leadership style to innovative work behavior: The role of group and psychological processes. Leadership \& Organization Development Journal, 36, 545-569. https://doi.org/10.1108/LODJ-10-2013-0131

Ogunfowora, B. (2009). The consequences of ethical leadership: comparisons with transformational leadership and abusive supervision (Unpublished Doctoral dissertation), University of Calgary.

Ohly, S., Sonnentag, S., \& Pluntke, F. (2006). Routinization, work characteristics and their relationships with creative and proactive behaviors. Journal of Organizational Behavior: The International Journal of Industrial, Occupational and Organizational Psychology and Behavior, 27, 257-279. https://doi.org/10.1002/job.376

Oldham, G. R., \& Cummings, A. (1996). Employee creativity: Personal and contextual factors at work. Academy of Management Journal, 39, 607-634. https://doi.org/10.5465/256657

Owens, B. P., \& Hekman, D. R. (2016). How does leader humility influence team performance? Exploring the mechanisms of contagion and collective promotion focus. Academy of Management Journal, 59, 1088-1111. http://dx.doi.org/10.5465/amj.2013.0660 
Owens, B. P., Yam, K. C., Bednar, J. S., Mao, J., \& Hart, D. W. (2019). The impact of leader moral humility on follower moral self-efficacy and behavior. Journal of Applied Psychology, 104, 146-163. http://dx.doi.org/10.1037/ap10000353

Oyer, B. J. (2015). Teacher Perceptions of Principals’ Confidence, Humility, and Effectiveness: Implications for Educational Leadership. Journal of School Leadership, 25, 684-719.

Park, S., \& Jo, S. J. (2018). The impact of proactivity, leader-member exchange, and climate for innovation on innovative behavior in the Korean government sector. Leadership \& Organization Development Journal, 39, 130-149. https://doi.org/10.1108/LODJ-092016-0216

Pan, J., Wu, Q., Zhou, W., \& Lou, Y. (2015). When is the leader's creativity related to the followers' creativity? A cross-level examination in China. Innovation, 17, 364-382. https://doi.org/10.1080/14479338.2015.1061897

Pan, W., Sun, L.-Y., \& Chow, I. H. S. (2012). Leader-member exchange and employee creativity: Test of a multilevel moderated mediation model. Human Performance, 25, 432-451. https://doi.org/10.1080/08959285.2012.721833

Panaccio, A., Henderson, D. J., Liden, R. C., Wayne, S. J., \& Cao, X. (2015). Toward an understanding of when and why servant leadership accounts for employee extra-role behaviors. Journal of Business and Psychology, 30, 657-675. https://doi.org/10.1007/s10869-014-9388-z

Pieterse, A.N., van Knippenberg, D., Schippers, M., \& Stam, D. (2010). Transformational and transactional leadership and innovative behavior: The moderating role of psychological empowerment. Journal of Organizational Behavior, 31, 609-623. https://doi.org/10.1002/job.650 
Pundt, A. (2015). The relationship between humorous leadership and innovative behavior. Journal of Managerial Psychology, 30, 878-893. https://doi.org/10.1108/JMP-03-20130082

Qu, R., Janssen, O., \& Shi, K. (2015). Transformational leadership and follower creativity: The mediating role of follower relational identification and the moderating role of leader creativity expectations. The Leadership Quarterly, 26, 286-299. https://doi.org/10.1016/j.leaqua.2014.12.004

Qu, R., Janssen, O., \& Shi, K. (2017). Leader-member exchange and follower creativity: The moderating roles of leader and follower expectations for creativity. The International Journal of Human Resource Management, 28, 603-626. https://doi.org/10.1080/09585192.2015.1105843

Rada, V. I. (2018). Examining the relationship between perceptions of organizational justice, innovative work behavior, and transformational leadership after controlling for gender (Unpublished Doctoral dissertation). Alliant International University

Rank, J., Nelson, N. E., Allen, T. D., \& Xu, X. (2009). Leadership predictors of innovation and task performance: Subordinates' self- esteem and self- presentation as moderators. Journal of Occupational and Organizational Psychology, 82, 465-489. https://doi.org/10.1348/096317908X371547

Ramos, D. (2002). Relationships among leader-member exchange quality, satisfaction with organizational communication, and creativity in entertainment organizations (Unpublished Doctoral dissertation). Northcentral University.

Rasool, G., Naseer, S., Syed, F., \& Ahmed, I. (2018). Despotic leadership and employee's outcomes: Mediating effect of impression management. Pakistan Journal of Commerce and Social Sciences, 12, 784-806.

Rego, A., Sousa, F., Marques, C., \& Cunha, M. P. E. (2012). Authentic leadership promoting 
employees' psychological capital and creativity. Journal of Business Research, 65, 429437. https://doi.org/10.1016/j.jbusres.2011.10.003

Rego, A., Sousa, F., Marques, C., \& Cunha, M. P. E. (2014). Hope and positive affect mediating the authentic leadership and creativity relationship. Journal of Business Research, 67, 200-210. https://doi.org/10.1016/j.jbusres.2012.10.003

Ribeiro, N., Duarte, A. P., \& Filipe, R. (2018). How authentic leadership promotes individual performance: Mediating role of organizational citizenship behavior and creativity. International Journal of Productivity and Performance Management, 67, 1585-1607. https://doi.org/10.1108/IJPPM-11-2017-0318

Rickards, T., Chen, M. H., \& Moger, S. (2001). Development of a self-report instrument for exploring team factor, leadership and performance relationships. British Journal of Management, 12, 243-250. https://doi.org/10.1111/1467-8551.00197

Saeed, B. B., Afsar, B., Shahjehan, A., \& Shah, S. I. (2019). Does transformational leadership foster innovative work behavior? The roles of psychological empowerment, intrinsic motivation, and creative process engagement. Economic Research, 32, 254-281. https://doi.org/10.1080/1331677X.2018.1556108

Sagnak, M. (2012). The empowering leadership and teachers' innovative behavior: The mediating role of innovation climate. African Journal of Business Management, 6, 16351641. https://doi.org/10.5897/AJBM11.2162

Sanda, A., \& Arthur, N. A. D. (2017). Relational impact of authentic and transactional leadership styles on employee creativity: The role of work-related flow and climate for innovation. African Journal of Economic and Management Studies, 8, 274-295. https://doi.org/10.1108/AJEMS-07-2016-0098

Sanders, K. S., Moorkamp, M., Torka, N., Groenveld, S., \& Groenveld, C. (2010). How to support innovative work behavior? The role of LMX and satisfaction with HR practice. 
Technology and Investment, 1, 59-68. https://doi.org/10.4236/ti.2010.11007

Schaffer, B. S., \& Riordan, C. M. (2013). Relational demography in supervisor- subordinate dyads: An examination of discrimination and exclusionary treatment. Canadian Journal of Administrative Sciences, 30, 3-17. https://doi.org/10.1002/cjas.1237

Schermuly, C. C., Meyer, B., \& Dämmer, L. (2013). Leader-member exchange and innovative behavior. Journal of Personnel Psychology, 12, 132-142. https://doi.org/10.1027/1866-5888/a000093

Schmidt, A. A. (2008). Development and validation of the toxic leadership scale (Unpublished Doctoral dissertation), University of Maryland.

Schuh, S. C., Zhang, X., \& Tian, P. (2013). For the Good or the Bad? Interactive effects of transformational leadership with moral and authoritarian leadership behaviors. Journal of Business Ethics, 116, 629-640. https://doi.org/10.1007/s10551-012-1486-0

Scott, S. (1993). The influence of climate perceptions on innovation behavior (Unpublished Doctoral dissertation), Department of Management, University of Cincinnati.

Scott, S. G., \& Bruce, R. A. (1998). Following the leader in R\&D: The joint effect of subordinate problem-solving style and leader-member relations on innovative behavior. Engineering Management, IEEE Transactions, 45, 3-10. https://doi.org/10.1109/17.658656

Searle, T. P. (2011). A multilevel examination of proactive work behaviors: contextual and individual differences as antecedents (Unpublished Doctoral dissertation), University of Nebraska.

Semedo, A. S., Coelho, A., \& Ribeiro, N. (2018). The relationship between authentic leaders and employees' creativity: What are the roles of affective commitment and job resourcefulness?. International Journal of Workplace Health Management, 11, 58-73. https://doi.org/10.1108/IJWHM-06-2017-0048 
Semedo, A. S. D., Coelho, A. F. M., Ribeiro, N. M. P. (2016). Effects of authentic leadership, affective commitment and job resourcefulness on employees' creativity and individual performance. Leadership \& Organization Development Journal, 37, 1038-1055. https://doi.org/10.1108/LODJ-02-2015-0029

Semedo, A. S. D., Coelho, A. F. M., Ribeiro, N. M. P. (2017). Authentic leadership and creativity: The mediating role of happiness. International Journal of Organizational Analysis, 25, 395-412. https://doi.org/10.1108/IJOA-03-2016-0994

Sercan, G. (2016). Authentic leadership on widespread organization: As an authentic leader provincial gendarmerie commander's impacts on creativity, organizational identification, leader-member exchange (LMX), and emergence of his staff's potential capabilities. (Unpublished Doctoral dissertation). ISCTE Business School, ISCTE-IUL Instituto Universitário de Lisboa.

Sethibe, T., \& Steyn, R. (2017). The impact of leadership styles and the components of leadership styles on innovative behavior. International Journal of Innovation Management, 21, 1750015. https://doi.org/10.1142/S1363919617500153

Shin, S. J., \& Zhou, J. (2003). Transformational leadership, conservation, and creativity: Evidence from Korea. The Academy of Management Journal, 46, 703-714. https://doi.org/10.2307/30040662

Shu, C. Y., Chiang, Y. H., \& Lu, C. H. (2018). Authoritarian leadership supervisor support and workers' compulsory citizenship behavior. International Journal of Manpower, 39, 468-485. https://doi.org/10.1108/IJM-10-2016-0191

Si, S., \& Wei, F. (2012). Transformational and transactional leaderships, empowerment climate, and innovation performance: A multilevel analysis in the Chinese context. European Journal of Work and Organizational Psychology, 21, 299-320. https://doi.org/10.1080/1359432X.2011.570445 
Škerlavaj, M., Černe, M., \& Dysvik, A. (2014). I get by with a little help from my supervisor: Creative-idea generation, idea implementation, and perceived supervisor support. The Leadership Quarterly, 25, 987-1000. https://doi.org/10.1016/j.leaqua.2014.05.003

Slåtten, T. (2014). Determinants and effects of employee's creative self-efficacy on innovative activities. International Journal of Quality and Service Sciences, 6, 326-326. https://doi.org/10.1108/IJQSS-03-2013-0013

Slåtten, T., Svensson, G., \& Sværi, S. (2011). Empowering leadership and the influence of a humorous work climate on service employees' creativity and innovative behavior in frontline service jobs. International Journal of Quality and Service Sciences, 3, 267-284. https://doi.org/10.1108/17566691111182834

Son, S. Y., Cho, D. H., \& Kang, S. W. (2017). The impact of close monitoring on creativity and knowledge sharing: The mediating role of leader- member exchange. Creativity and Innovation Management, 26, 256-265. https://doi.org/10.1111/caim.12219

Song, D., Liu, H., Gu, J., \& He, C. (2018). Collectivism and employees' innovative behavior: The mediating role of team identification and the moderating role of leader- member exchange. Creativity and Innovation Management, 27, 221-231. https://doi.org/10.1111/caim.12253

Sönmez, B., \& Yildırım, A. (2019). The mediating role of autonomy in the effect of proinnovation climate and supervisor supportiveness on innovative behavior of nurses. European Journal of Innovation Management, 22, 41-58. https://doi.org/10.1108/EJIM05-2018-0088

Sosik, J. J., Kahai, S. S., \& Avolio, B. J. (1999). Leadership style, anonymity, and creativity in group decision support systems: The mediating role of optimal flow. Journal of Creative Behavior, 33, 227-256. https://doi.org/10.1002/j.2162-6057.1999.tb01405.x 
Steinmann, B., Nübold, A., \& Maier, G. W. (2016). Validation of a German version of the ethical leadership at work questionnaire by Kalshoven et al. (2011). Frontiers in Psychology, 7, 446. http://dx.doi.org/10.3389/fpsyg.2016.00446

Suifan, T. S., Abdallah, A. B., \& Al Janini, M. (2018). The impact of transformational leadership on employees' creativity: The mediating role of perceived organizational support. Management Research Review, 41, 113-132. https://doi.org/10.1108/MRR-022017-0032

Sun, Y. (2016). Does servant leadership inspire personnel's innovation performance: Performance control as a moderator. International Journal of Business Administration, 7, 86-91. https://doi.org/10.5430/ijba.v7n2p86

Sun, L. Y., Zhang, Z., Qi, J., \& Chen, Z. (2012). Empowerment and creativity: A cross-level investigation. The Leadership Quarterly, 23, 55-65. https://doi.org/10.1016/j.leaqua.2011.11.005

Taylor, A. M. (2012). Cultivating an engaged workforce: The roles of leader personality, motivation, and leadership style (Unpublished Doctoral dissertation). University of South Florida.

Taylor, A. S. (2015). Transformational leadership, diversity, and creativity at work: A moderated mediation model (Unpublished Doctoral dissertation). Portland State University.

Tian, Q., \& Sanchez, J. I. (2017). Does paternalistic leadership promote innovative behavior? The interaction between authoritarianism and benevolence. Journal of Applied Social Psychology, 47, 235-246. https://doi.org/10.1111/jasp.12431

Tierney P. (1992). The contribution of leadership, supportive environment, and individual attributes to creative performance: A quantitative field study (Unpublished Doctoral dissertation), Department of Management, University of Cincinnati. 
Tierney, P., Farmer, S. M., \& Graen, G. B. (1999). An examination of leadership and employee creativity: The relevance of traits and relationships. Personnel Psychology, 52, 591-620. https://doi.org/10.1111/j.1744-6570.1999.tb00173.x

Topcu, M. K., Gursoy, A., \& Gurson, P. (2015). The role of the servant leadership on the relation between ethical climate perception and innovative work. European Research Studies, 18, 67-79.

Tremblay, M., \& Gibson, M. (2016). The role of humor in the relationship between transactional leadership behavior, perceived supervisor support, and citizenship behavior. Journal of Leadership \& Organizational Studies, 23, 39-54. http://dx.doi.org/10.1177/1548051815613018

Tse, H., \& Chiu, W. (2014). Transformational leadership and job performance: A social identity perspective. Journal of Business Research, 67, 2827-2835. https://doi.org/10.1016/j.jbusres.2012.07.018

Tse, H. H., To, M. L., \& Chiu, W. C. (2018). When and why does transformational leadership influence employee creativity? The roles of personal control and creative personality. Human Resource Management, 57, 145-157. https://doi.org/10.1002/hrm.21855

Tu, Y., \& Lu, X. (2013). How ethical leadership influence employees' innovative work behavior: A perspective of intrinsic motivation. Journal of Business Ethics, 116, 441455. https://doi.org/10.1007/s10551-012-1509-X

Tuan, L. T. (2019). Coach humility and player creativity: The roles of knowledge sharing and group diversity. Sport Management Review. https://doi.org/10.1016/j.smr.2019.02.004

Tung, F. C. (2016). Does transformational, ambidextrous, transactional leadership promote employee creativity? Mediating effects of empowerment and promotion focus. International Journal of Manpower, 37, 1250-1263. https://doi.org/10.1108/IJM-092014-0177 
Tung, F., \& Yu, T. (2015). Does innovation leadership enhance creativity in high-tech industries? Leadership \& Organization Development Journal, 37, 579-592. https://doi.org/10.1108/LODJ-09-2014-0170

Turunc, O., Celik, M., Tabak, A., \& Kabak, M. (2010). The impact of transformational leadership and contingent reward leadership styles on innovative behavior: Mediating role of leader-member exchange quality. International Journal of Business and Management Studies, 2, 69-79.

Unsworth, K. L., Wall, T. D., \& Carter, A. (2005). Creative requirement: A neglected construct in the study of employee creativity? Group \& Organization Management, 30, 541-560. https://doi.org/10.1177/1059601104267607

Vazquez, L. (2016). Examining the relationship between perceived transformational leadership styles and the innovative performance of the engineering team member in emerging and legacy space organizations (Unpublished Doctoral dissertation), Our Lady of the Lake University.

Volmer, J., Spurk, D., \& Niessen, C. (2012). Leader-member exchange (LMX), job autonomy, and creative work involvement. The Leadership Quarterly, 23, 456-465. https://doi.org/10.1016/j.leaqua.2011.10.005

Walumbwa, F. O., Wu, C., \& Orwa, B. (2008). Contingent reward transactional leadership, work attitudes, and organizational citizenship behavior: The role of procedural justice climate perceptions and strength. The Leadership Quarterly, 19, 251-265. http://dx.doi.org/10.1016/j.leaqua.2008.03.004

Wang, C. J. (2016). Does leader-member exchange enhance performance in the hospitality industry? The mediating roles of task motivation and creativity. International Journal of Contemporary Hospitality Management, 28, 969-987. https://doi.org/10.1108/IJCHM10-2014-0513 
Wang, P., Chang, L. \& Wang, S. Q. (2018) Employee voice behavior and innovative behavior: Comparison of the influence of benevolent leadership and authoritative leadership. Paper presented at 4th International Conference on Social Science and Management

Wang, A. C., \& Cheng, B. S. (2010). When does benevolent leadership lead to creativity? The moderating role of creative role identity and job autonomy. Journal of Organizational Behavior, 31, 106-121. https://doi.org/10.1002/job.634

Wang, A. C., Chiang, J. T. J., Tsai, C. Y., Lin, T. T., \& Cheng, B. S. (2013). Gender makes the difference: The moderating role of leader gender on the relationship between leadership styles and subordinate performance. Organizational Behavior and Human Decision Processes, 122, 101-113. https://doi.org/10.1016/j.obhdp.2013.06.001

Wang, X. H., Fang, Y., Qureshi, I., \& Janssen, O. (2015). Understanding employee innovative behavior: Integrating the social network and leader-member exchange perspectives. Journal of Organizational Behavior, 36, 403-420. https://doi.org/10.1002/job.1994

Wang, Y., Liu, J., \& Zhu, Y. (2018). How does humble leadership promote follower creativity? The roles of psychological capital and growth need strength. Leadership \& Organization Development Journal, 39, 507-521. https://doi.org/10.1108/LODJ-032017-0069

Wang, P., \& Rode, J. (2010). Transformational leadership and follower creativity: The moderating effects of identification with leader and organizational climate. Human Relations, 63, 1105-1128. https://doi.org/10.1177/0018726709354132

Wang, Y., Tang, C., Naumann, S. E., \& Wang, Y. (2017). Paternalistic leadership and employee creativity: A mediated moderation model. Journal of Management \& Organization, 25, 137-156. https://doi.org/10.1017/jmo.2017.8 
Wang, C. J., Tsai, H. T., \& Tsai, M. T. (2014). Linking transformational leadership and employee creativity in the hospitality industry: The influences of creative role identity, creative self-efficacy, and job complexity. Tourism Management, 40, 79-89. https://doi.org/10.1016/j.tourman.2013.05.008

Wang, D., Xue, H., \& Su, H. (2010). Influence of work support on employee creativity: An empirical examination in the Peoples Republic of China. African Journal of Business Management, 4, 1546-1553.

Wang, J., Zhang, Z., \& Jia, M. (2017). Understanding how leader humility enhances employee creativity: The roles of perspective taking and cognitive reappraisal. The Journal of Applied Behavioral Science, 53, 5-31.

https://doi.org/10.1177/0021886316678907

Wang, P., \& Zhu, W. (2011). Mediating role of creative identity in the influence of transformational leadership on creativity: Is there a multilevel effect? Journal of Leadership \& Organizational Studies, 18, 25-39. https://doi.org/10.1177/1548051810368549

Washington, R. R., Sutton, C. D., \& Sauser Jr, W. I. (2014). How distinct is servant leadership theory? Empirical comparisons with competing theories. Journal of Leadership, Accountability and Ethics, 11. 11 - 25.

Weaver, C. P. (2017). Leadership style, innovative work behavior, and the mediating effect of innovation climate on individual job satisfaction and team effectiveness (Unpublished Doctoral dissertation), Regent University.

Wei, F., Yuan, X., \& Di, Y. (2010). Effects of transactional leadership, psychological empowerment and empowerment climate on creative performance of subordinates: A cross-level study. Frontiers of Business Research in China, 4, 29-46. https://doi.org/10.1007/s11782-010-0002-6 
Weng, R. H., Huang, C. Y., Chen, L. M., \& Chang, L. Y. (2013). Exploring the impact of transformational leadership on nurse innovation behavior: A cross-sectional study. Journal of Nursing Management, 23, 427-439. https://doi.org/10.1111/jonm.12149

White, C. D., Campbell, K. S., \& Kacmar, M. K. (2012). Development and validation of a measure of leader rapport management: The LRM scale. Journal of Behavioral \& Applied Management, 13, 121-149.

Williams, W. A., Brandon, R., Hayek, M., Haden, S. P., \& Atinc, G. (2017). Servant leadership and followership creativity: The influence of workplace spirituality and political skill. Leadership \& Organization Development Journal, 38, 178-193. https://doi.org/10.1108/LODJ-02-2015-0019

Wu, Y. (2018). The influence of paternalistic leadership on the creative behavior of knowledge workers-based on the perspective of psychological contractual perception. Open Journal of Business and Management, 6, 478-487.

Wu, W., Liu, Y., Kim, Y., \& Gao, P. (2018). How does emotional conflict affect innovation behavior? The moderating roles of leader-member exchange and team-member exchange. International Journal of Conflict Management, 29, 327-346. https://doi.org/10.1108/IJCMA-09-2017-0094

Xu, B., Zhao, S., Li, C., \& Lin, C. (2017). Authentic leadership and employee creativity: Testing the multilevel mediation model. Leadership \& Organization Development Journal, 38, 482-498. https://doi.org/10.1108/LODJ-09-2015-0194

Yang, J., Liu, H., \& Gu, J. (2017). A multi-level study of servant leadership on creativity: The roles of self-efficacy and power distance. Leadership \& Organization Development Journal, 38, 610-629. https://doi.org/10.1108/LODJ-10-2015-0229 
Yasir, M., \& Majid, A. (2019). Boundary integration and innovative work behavior among nursing staff. European Journal of Innovation Management, 22, 2-22. https://doi.org/10.1108/EJIM-02-2018-0035

Yoshida, D. T., Sendjaya, S., Hirst, G., \& Cooper, B. (2014). Does servant leadership foster creativity and innovation? A multi-level mediation study of identification and prototypicality. Journal of Business Research, 67, 1395-1404. https://doi.org/10.1016/j.jbusres.2013.08.013

Yuan, P. (2005). Modeling, simulation and analysis of multi-barge flotillas impacting bridge piers. UKnowledge, University of Kentucky. Retrieved from https://uknowledge.uky.edu/cgi/viewcontent.cgi?referer=https://www.google.com.au/\&ht tpsredir=1\&article=1313\&context=gradschool_diss

Yuan, L., Zhang, L., \& Tu, Y. (2018). When a leader is seen as too humble: a curvilinear mediation model linking leader humility to employee creative process engagement. Leadership \& Organization Development Journal, 39, 468-481. https://doi.org/10.1108/LODJ-03-2017-0056

Zacher, H., \& Johnson, E. (2015). Leadership and creativity in higher education. Studies in Higher Education, 40, 1210-1225. https://doi.org/10.1080/03075079.2014.881340

Zahra, T. T., \& Waheed, A. (2017). Influence of ethical leadership on innovative work behavior: Examination of individual-level psychological mediators. Pakistan Journal of Commerce and Social Sciences, 11, 448-470.

Zaitouni, M., \& Ouakouak, M. L. (2018). Key predictors of individual creativity in a Middle Eastern culture: The case of service organizations. International Journal of Organizational Analysis, 26, 19-42. https://doi.org/10.1108/IJOA-03-2017-1139 Zhang, Y. W. (2013). Leaders' daily work demands, recovery, and leadership behaviors (Unpublished Doctoral dissertation), Arizona State University. 
Zhang, X., \& Bartol, K. M. (2010). Linking empowering leadership and employee creativity: The influence of psychological empowerment, intrinsic motivation, and creative process management. Academy of Management Journal, 53, 107-128. https://doi.org/10.5465/AMJ.2010.48037118

Zhang, J., Fan, Y., \& Zhang, X. (2015). The role of power motivation in creativity: A moderated mediation model. Social Behavior and Personality: An International Journal, 43, 613-628. ttps://doi.org/10.2224/sbp.2015.43.4.613

Zhang, S., Ke, X., Wang, X. H., \& Liu, J. (2018). Empowering leadership and employee creativity: A dual- mechanism perspective. Journal of Occupational and Organizational Psychology, 91, 896-917. https://doi.org/10.1111/joop.12219

Zhang, H., Kwan, H.K., Zhang, X. \& Wu, L.Z. (2014). High core self-evaluators maintain creativity: A motivational model of abusive supervision. Journal of Management, 40, 1151-1174. https://doi.org/10.1177/0149206312460681

Zhang, Y., LePine, J. A., Buckman, B. R., \& Wei, F. (2014). It's not fair... or is it? The role of justice and leadership in explaining work stressor-job performance relationships. Academy of Management Journal, 57, 675-697. https://doi.org/10.5465/amj.2011.1110

Zhang, Y., Zheng, J., \& Darko, A. (2018). How does transformational leadership promote innovation in construction? The mediating role of innovation climate and the multilevel moderation role of project requirements. Sustainability, 10, 1506-1525. https://doi.org/10.3390/su10051506

Zhang, X., \& Zhou, J. (2014). Empowering leadership, uncertainty avoidance, trust, and employee creativity: Interaction effects and a mediating mechanism. Organizational Behavior and Human Decision Processes, 124, 150-164. https://doi.org/10.1016/j.obhdp.2014.02.002 
Zhao, H., Kessel, M., \& Kratzer, J. (2014). Supervisor-subordinate relationship, differentiation, and employee creativity: A self- categorization perspective. Journal of Creative Behavior, 48, 165-184. https://doi.org/10.1002/jocb.46

Zhou, Q., \& Pan, W. (2015). A cross-level examination of the process linking transformational leadership and creativity: The role of psychological safety climate. Human Performance, 28, 405-424. https://doi.org/10.1080/08959285.2015.1021050

Zhu, C., \& Mu, R. (2016). Followers' innovative behavior in organizations: The role of transformational leadership, psychological capital and knowledge sharing. Frontiers of Business Research in China, 10, 636-663. 10.3868/s070-005-016-0023-0

Zhu, W., Wang, G., Zheng, X., Liu, T., \& Miao, Q. (2013). Examining the role of personal identification with the leader in leadership effectiveness a partial nomological network. Group \& Organization Management, 38, 36-67.

https://doi.org/10.1177/1059601112456595 